\title{
Emergency Response to a Highway Accident in Springfield, Massachusetts, on December 16,1991
}

\section{U.S. Nuclear Regulatory Commission}

\section{Office of Nuclear Material Safety and Safeguards}

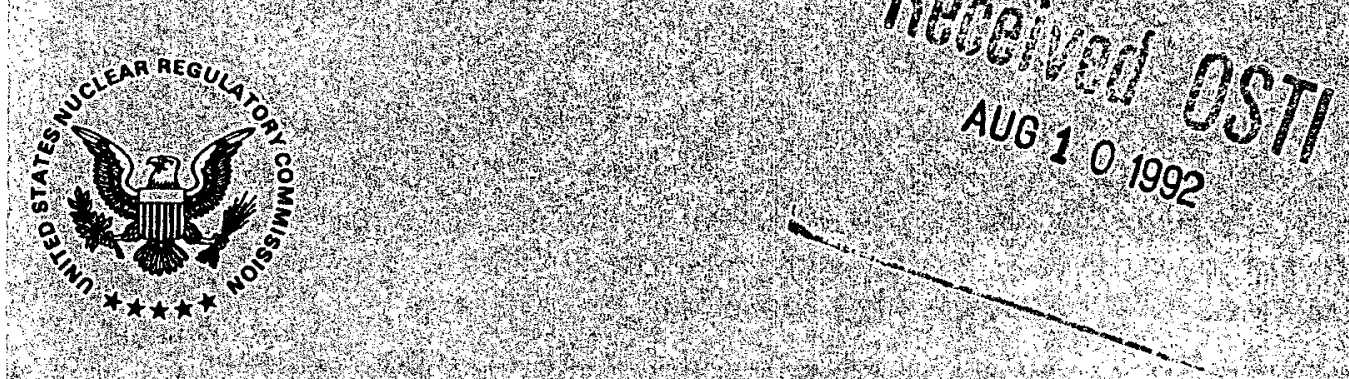




\section{DISCLAIMER}

This report was prepared as an account of work sponsored by an agency of the United States Government. Neither the United States Government nor any agency Thereof, nor any of their employees, makes any warranty, express or implied, or assumes any legal liability or responsibility for the accuracy, completeness, or usefulness of any information, apparatus, product, or process disclosed, or represents that its use would not infringe privately owned rights. Reference herein to any specific commercial product, process, or service by trade name, trademark, manufacturer, or otherwise does not necessarily constitute or imply its endorsement, recommendation, or favoring by the United States Government or any agency thereof. The views and opinions of authors expressed herein do not necessarily state or reflect those of the United States Government or any agency thereof. 


\section{DISCLAIMER}

Portions of this document may be illegible in electronic image products. Images are produced from the best available original document. 


\section{AVAIIABIITY NOTICE}

Availability of Reference Materials Gited in NRE Publications

Most documents cited in NRE publications wil be available from one of the following sources:

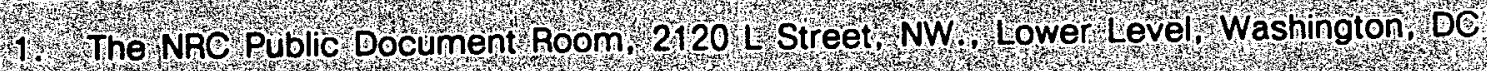
20555

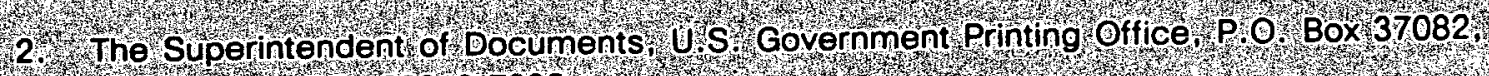
Washington, QC $20013=7082$

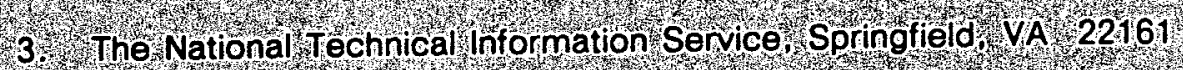

Although the listing that follows represents the majority of cocuments cited in NRC publica tions. it is not intended to be exhaustive.

Referenced documents available for inspection and cop ing for a fee from the NRC Public Document Poom include NRe correspondence and internal NRC memoranda. NRe bulletins.

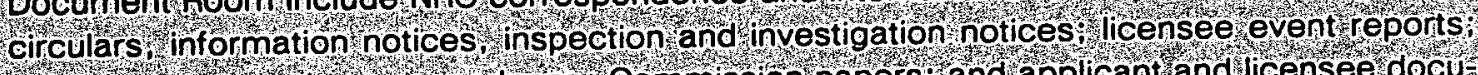
venoor reports and correspondence commission papers. and appicant and licensed documents and correspondence.

The following documents in the NuREG series are available for purchase from the GPO Sales program. formal NRC staff and contractor reports. NRG sponsored conference proceed ings, international agreement reports, grant publications, and NAC booklets and brochures Also available are regulatory guides NRe regulations in the Code of gederal Regulations and Nuclear Regulaton Commissionissuances.

bocuments available from the National Technical hormation Service include NUREG series reports and technical reports prepared by other rederal agencies and reports prepared by the Atomic Energy Commission foreruner agency to the Nuelearhegulatery commission.

Bocuments available trom public and special technic al libraries nclude allopen literature tems, suchas books, founal articles, and transactions federal Rogister hotices, frederal and State legislation, and congressional reports can usually be obtained from these libraries

Documents such as theses dissertations, foreign reports and translations. and hon NBC conference proceedings are available for purchase from the organization sponsoring the publication cited.

Single coples of NRC drattreports are available free, to the extent of supply, upon written request to the Office of Administration. Distribution and Mail Services Section. U.S. Nuclear Regulatory Commission. Washington. De 20555.

Copies of industy codes and standards used in a substantive manner in the NRC regutatory process are maintained at the NRC Library. 7920 Norfolk Avenue, Bethesda. Maryland for use by the public Godes and standards are usually copyrighted and may be purchased from the originating organization or if they are American National Standards, from the

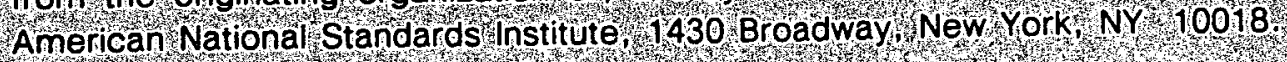




\section{Emergency Response to a} Highway Accident in Springfield, Massachusetts, on December 16, 1991

Manuscript Completed: May 1992

Date Published: June 1992

Division of Safeguards and Transportation

Office of Nuclear Material Safety and Safeguards

U.S. Nuclear Regulatory Commission

Washington, DC 20555

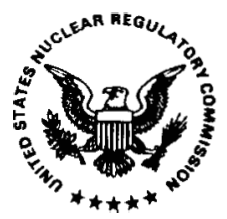


$$
\text { . }
$$ 


\begin{abstract}
On December 16, 1991, a truck carrying unirradiated (fresh) nuclear fuel was involved in an accident on U.S. Interstate 91, in Springfield, Massachusetts. This report describes the emergency response measures undertaken

by local, State, Federal, and private parties. The report also discusses "lessons learned" from the response to the accident and suggests areas where improvements might be made.
\end{abstract}




\section{CONTENTS}

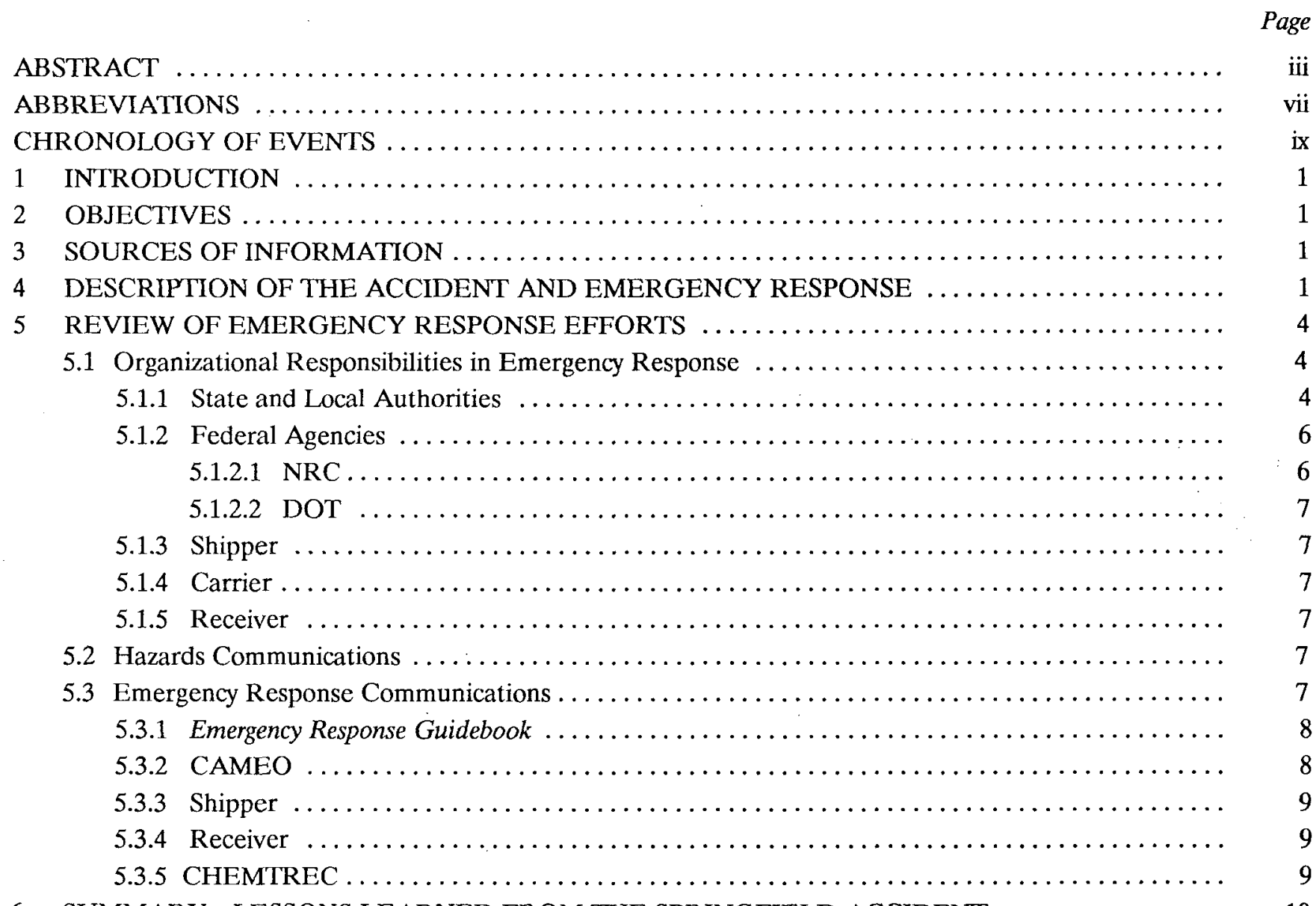

6 SUMMARY_LESSONS LEARNED FROM THE SPRINGFIELD ACCIDENT $\ldots \ldots \ldots \ldots \ldots \ldots$

\section{APPENDICES}

A Shipping Papers .

B Accident Investigation Report, U.S. Department of Transportation, Federal Highway

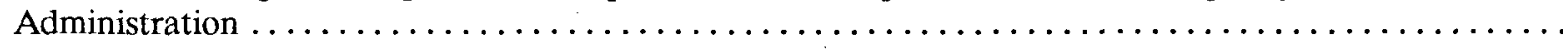

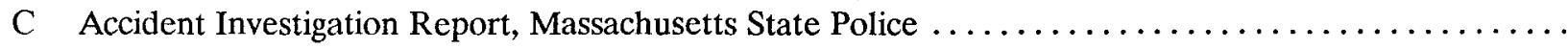

D Springfield Fire Department Reports and Correspondence $\ldots \ldots \ldots \ldots \ldots \ldots \ldots \ldots \ldots \ldots . . . . .$.

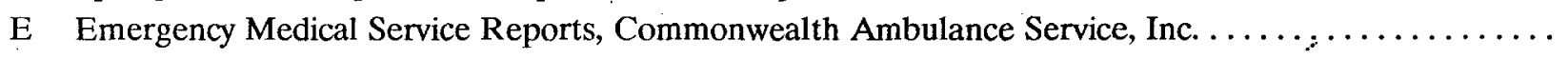

F City of Springfield Integrated Hazardous Materials Incident Response Plan $\ldots \ldots \ldots \ldots \ldots \ldots$

G Chronology of Events and Phone Records, Vermont Yankee Power Corporation ...............

H Summary of Telephone Conversations on December, 16, 1991, General Electric Company, Wilmington, North Carolina .

J NRC Response to Accidents Occurring During the Transportation of Radioactive Material;

K Guide 63 from the 1990 Emergency Response Guidebook, U.S. Department of Transportation; 


$\begin{array}{ll} & \\ \text { BWR } & \text { ABBREVIATIONS } \\ \text { CAMEO } & \text { coiling water reactor } \\ \text { CHEMTREC } & \text { Chemical Emergency Transportation Emergency Center } \\ \text { DOE } & \text { U.S. Department of Energy } \\ \text { DOT } & \text { U.S. Department of Transportation } \\ \text { EPA } & \text { U.S. Environmental Protection Agency } \\ \text { ERP } & \text { emergency response plan } \\ \text { FEMA } & \text { Federal Emergency Management Agency } \\ \text { GE } & \text { General Electric Company, Wilmington, North Carolina } \\ \text { LLNL } & \text { Lawrence Livermore National Iaboratories } \\ \text { NIAT } & \text { Nuclear Incident Advisory Team } \\ \text { NOAA } & \text { National Oceanic and Atmospheric Administration } \\ \text { NRC } & \text { U.S. Nuclear Regulatory Commission } \\ \text { MDPH } & \text { Massachusetts Department of Public Health } \\ \text { MEMA } & \text { Massachusetts Emergency Management Agency } \\ \text { MSDS } & \text { material safety data sheet } \\ \text { MSP } & \text { Massachusetts State Police } \\ \text { RIDS } & \text { response information data sheets } \\ \text { SCBA } & \text { self-contained breathing apparatus } \\ \text { UN } & \text { United Nations } \\ \text { UO } 2 & \text { uranium dioxide } \\ \text { USDA } & \text { Westover Air Force Base }\end{array}$




\section{CHRONOLOGY OF EVENTS ACCIDENT IN SPRINGFIELD, MASSACHUSETTS}

December 16, 1991

3:15 am

3:18 am

3:24 am

$3: 24$ am

$3: 26$ am

3:30 am

3:32 am

$3: 35 \mathrm{am}$

3:50 am

3:50 am

3:50 am

3:56 am

4:00 am

4:02 am

4:04 am

4:15 am

4:43 am

4:50 am

4:50-5:10 am

4:53 am

5:00 am

5:02 am

5:26 am

$5: 30$ am

5:54 am

6:00 am

6:00 am

12:15-2:30 pm

3:00 pm

$3: 15 \mathrm{pm}$

4:45 pm

Accident occurs on I-91.

Springfield MSP receive report of accident.

MSP arrive at scene.

MSP request ambulance and fire department assistance at scene.

Level 1 Hazardous Materials Emergency declared.

Springfield Fire Department arrives at accident scene.

Ambulances arrive at scene.

Fire Department verifies identity of cargo from shipping papers.

Command Post established.

Fire Department contacts GE.

Fire Department contacts VY.

Ambulance carrying truck drivers leaves scene.

Ambulance with automobile driver arrives at hospital.

Fire Department speaks with individual incorrectly assumed to be an employee of NRC.

Truck drivers arrive at hospital.

Decision made by fire chief not to fight fire.

NRC Operations Center notified of accident by GE.

Incident upgraded to a Level 2 Hazardous Materials emergency.

GE returns call to Command Post.

Chicopee Police Department contacts CHEMTREC.

Conference call coordinated by NRC.

CHEMTREC returns call to Chicopee Police Department.

NRC notifies DOT National Response Center followed by DOE, FEMA, EPA, FDA, and USDA.

VY representative arrives at accident scene.

NRC contacts Command Post.

VY completes radiation survey of scene.

NIAT arrives at accident scene and conducts radiological survey. Fire is essentially out.

\section{December 17, 1991}

$5: 45 \mathrm{pm}$

DOT issues Emergency Exemption for transporting containers back to GE-Wilmington.

\section{December 18, 1991}

10:00 am

Trucks with repackaged containers depart Westover AFB en route to Wilmington, North Carolina.

December 19, 1991

10:00 am

Shipment arrives at GE-Wilmington. GE declares Site Area Emergency over. 


\section{INTRODUCTION}

On December 16, 1991, a truck carrying unirradiated (fresh) nuclear fuel was involved in an accident on U.S. Interstate 91 in Springfield, Massachusetts. The shipment of fresh fuel was the third of five being made from General Electric Company's (GE's) fuel fabrication plant in Wilmington, North Carolina, to the Vermont Yankee Nuclear Power Station (VY) in Vernon, Vermont, for a refueling outage scheduled for March 1992. The fuel shipment consisted of 24 fresh fuel assemblies, ${ }^{1}$ packaged two each, in 12 Model RA-2/RA-3 shipping containers. ${ }^{2}$

The accident occurred at approximately $3: 15 \mathrm{a} . \mathrm{m}$., when an automobile traveling in the wrong direction on Interstate 91 collided head-on with the oncoming truck. As a result of the accident, the truck and shipping containers carrying the fresh fuel were engulfed in a fire that lasted for almost 3 hours. Despite the collision and subsequent fire, there were no deaths or serious injuries, and there was no release of radioactive material. The accident did, however, result in substantial property loss, including the truck, shipping containers, and damaged fuel assemblies.

\section{OBJECTIVES}

The primary objectives of this report are to review the guidance available to State and Federal authorities in responding to the Springfield accident, and to determine what actions were taken by the various parties involved. The report focuses on two critical aspects of emergency response: organizational responsibility, and hazardous material and emergency response communications. The report also identifies areas for improvement.

This report does not try to quantify the damage suffered by individual shipping containers during the accident nor assess whether the Model RA-2/RA-3 shipping containers performed as expected. The accident environment and damage that the shipping containers and fuel assemblies experienced during the accident are the subjects of a separate report prepared by Lawrence Livermore National Laboratory (LLNL) (See NUREG/CR-5892, "A Highway Accident Involving Unirradiated Nuclear Fuel in Springfield, Massachusetts, on December 16, 1991.”)

\footnotetext{
'The assemblies were GE $8 \times 8$ boiling water reactor (BWR) assemblies with an average uranium dioxide enrichment of 3.2 percent. The uranium dioxide fuel in the assemblies is in the form of ceramic pellets housed in sealed zircaloy tubes (fuel rods).

2The U.S. Nuclear Regulatory Commission (NRC) has certified the Model RA-2/RA-3 shipping container as a Type A container for fissile materials. It consists primarily of an inner steel container approximately 12 in. by 18 in. by $15 \mathrm{ft}$. long, packaged within a wooden overpack.
}

\section{SOURCES OF INFORMATION}

The information used to prepare this report was supplied by the parties listed below and comes primarily from official agency reports, personal records of telephone conversations, eyewitness reports, interviews, video tapes, and logbooks.

- Springfield Fire Department

- Springfield Office of Emergency Preparedness

- Springfield Police Department

- Station WWLP-TV, Springfield

- Commonwealth Ambulance Service, Springfield

- Massachusetts State Police

- Massachusetts Department of Public Health Nuclear Incident Advisory Team (NIAT)

- General Electric Company in Wilmington, North Carolina

- Vermont Yankee Nuclear Power Station in Vernon, Vermont

- Chemical Transportation Emergency Center (CHEMTREC)

- U.S. Department of Transportation Office of Hazardous Materials Technology

- U.S. Department of Transportation Federal Highway Administration, Region I

- Lawrence Livermore National Laboratory

- U.S. Nuclear Regulatory Commission, Operations Center

- U.S. Nuclear Regulatory Commission, Region I

- Truck Driver involved in accident

Since some of the information supplied by the various parties is inconsistent or contradictory, an attempt has been made to include the most significant information (in its original form) in the appendices to this report.

\section{DESCRIPTION OF THE ACCIDENT AND EMERGENCY RESPONSE}

At approximately 3:15 a.m., on December 16, 1991, a truck carrying unirradiated nuclear fuel packaged in NRC-certified Model RA-2/RA-3 shipping containers was involved in an accident in Springfield, Massachusetts. The truck was traveling north on Interstate 91 when it was approached head-on by a Toyota Tercel heading in the wrong direction. The truck driver was unable to avoid the automobile and the vehicles collided on their right front sides. The truck then impacted the center steel guardrail, 
crossed the highway and hit the right shoulder concrete barrier, then recrossed the highway, impacting the center guardrail again before coming to rest.

The Massachusetts State Police (MSP) received a report of the accident via CB radio at approximately 3:18 a.m. The MSP responded to the accident within minutes and blocked traffic on Interstate 91 in both directions. At approximately 3:24 a.m., the MSP requested assistance from the Springfield Fire Department and emergency medical personnel. The MSP were able to identify the truck's cargo as radioactive material from the shipping papers supplied by the truck driver. The truck's cargo could not have been identified by placarding, since U.S. Department of Transportation (DOT) regulations did not require the shipment to be placarded. It was also impossible to identify the cargo from the radioactive labels on the shipping containers, since the containers were covered by a tarpaulin.

Records from the Commonwealth Ambulance Service show that $t$ wo ambulances were dispatched at 3:24 a.m. The ambulance drivers were informed, en route, that the accident involved a truck carrying hazardous materials, but were not told that the truck was carrying radioactive material until they reached the accident scene. ${ }^{3}$ Both ambulances reached the scene at approximately 3:32 a.m. The truck driver and alternate driver (his wife) were helped in to the back of one of the ambulances by its crew, but were left unattended during the trip to the hospital because of concerns of possible contamination. The ambulance carrying the truck drivers left the accident scene at 3:56 a.m. While en route to the hospital, one of the ambulance drivers radioed ahead to inform the emergency room staff that the accident had involved an unknown radioactive material and that the incoming patients could be contaminated. (The hospital did not receive detailed information on the type of radioactive material involved until nearly a half-hour after the patients had arrived at the emergency room.)

The ambulance carrying the truck drivers arrived at the hospital at approximately 4:04 a.m. The driver of the automobile was transported to the hospital in the second ambulance, which arrived at about 4:00 a.m. As the patients arrived at the hospital, they were taken to a decontamination room to await examination. The patients were later examined by a doctor from the Radiation Safety Unit and found to be uncontaminated. All three patients were treated for minor injuries and released.

\footnotetext{
${ }^{3}$ Emergency Medical Services Report Nos. 918088, 918089, and 918551, Commonwealth Ambulance Service, Inc., dated December 16, 1991. (See Appendix E.)
}

The Springfield Fire Department dispatched units at approximately 3:25 a:m. When the responding fire units arrived, the State police transferred control of the accident scene to the fire department. There are conflicting descriptions of the extent of the fire when the fire department arrived. Some witnesses have described the fire as initially involving only the cab area and rear tires. ${ }^{4}$ Others describe the fire as more widespread. ${ }^{5}$

The MSP advised the fire department that the truck was carrying a radioactive material-uranium dioxide $\left(\mathrm{UO}_{2}\right)$. Based on this information, the fire department declared a Level 1 Hazardous Material Incident. A Level 1 Hazardous Material Incident is defined as an incident that police, fire department, Department of Public Works, and emergency medical personnel can easily handle with initial emergency response crews. Evacuation is not necessary. ${ }^{6}$

The fire department was able to verify the identity of the cargo at approximately 3:35 a.m., when the shipping papers were supplied by the MSP. The shipping papers listed the cargo as "RADIOACTIVE MATERIAL, Fissile, n.o.s., UN 2918" " and as solid uranium dioxide. The shipping papers also referenced Guide 63 in the DOT Emergency Response Guidebook as the appropriate guidance to be used for emergency response. After consulting Guide 63, the fire department attempted to obtain additional guidance from CAMEO (Computer Aided Management of Emergency Operations), a hazardous material database. However, CAMEO did not contain an entry for uranium dioxide.

At this point the fire department decided to let the fire burn until additional information could be obtained about the truck's cargo from the shipper. At the time the decision was made, the shipping containers on the rear section of the trailer were still intact and not on fire. However, the shipping containers on the front section of the trailer were on fire, and two of the containers had apparently fallen off the trailer, landing on the highway between the truck and the center median strip. ${ }^{8}$

At approximately 3:50 a.m., a command post was established at a nearby hotel to monitor response efforts. The Springfield Fire Department contacted GE in Wil-

\footnotetext{
${ }^{4}$ The truck drivers, in an intervicw with LLNL, reported that the fire was initially confined to the cab and rear tires. R. Carlson, LLNL, personal communication.

${ }^{5}$ The ambulance drivers reported that the truck was fully engulfed in fire, when they arrived at 3:32 a.m.

6"City of Springfield Integrated Hazardous Materials Incident Response Plan," page 24. (See Appendix F.)

The proper shipping name required by DOT regulations. The abbreviation "n.o.s." means not otherwise specified.

${ }^{\theta}$ Memorandum from J. F. Friberg, Lieutenant, Rescue Squad, to Fire Chief Gary Cassanelli, dated December 29, 1991.
} 
mington, North Carolina, from the command post, via the 24-hour emergency response number listed on the shipping papers. ${ }^{9}$ According to fire department officials, GE advised the fire department "...not to approach the vehicle, to let the fire burn and to keep everybody away," and promised to call back with additional information. ${ }^{10} \mathrm{~A}$ summary of telephone contacts that GE supplied for the morning of December 16 show that a call was received from the Springfield police between 3:53 and 4:04 a.m. The GE summary does not reference any advice that may have been given out during the initial phone call. It does show that the GE manager for Nuclear Safety Engineering advised the fire department to put out the fire in a subsequent call. However, the return call was not placed until 4:50 a.m. ${ }^{11}$

The fire department also contacted VY, in Vernon, Vermont, at approximately 3:50 a.m. to notify it of the accident and to request information about the hazard of the material. The fire department believed that the information given them was consistent with that given by GE, that is, to isolate the area, keep people away, do not attempt to approach the vehicle. The fire department was also informed that a response team would be sent from VY and would arrive within an hour.

According to VY records, VY advised the fire department that water could be used to fight the fire with precautions. These precautions included having all fire fighters down wind of the fire wear full turn-out gear and SCBAs (self-contained breathing apparatus), and treating all personnel, water, and equipment as contaminated until they could be surveyed. If the fire department chose not to fight the fire, VY stated that an evacuation area of 100 yards surrounding the fire would be adequate to protect the public. The fire department indicated to VY that it would probably let the fire burn, since it appeared that the hazard to the public would be minimal. ${ }^{12}$

At this point, the fire department upgraded the event to a Level II incident. Declaring a Level II Hazardous Mate-

\footnotetext{
${ }^{\circ} \mathrm{A} 24$-hour emergency response number is required by DOT regulations (49 CFR 172.604). The number must be monitored at all times and must be the number of a person who is knowledgeable about the hazardous material being shipped and has emergency response information for that material, or has immediate access to a person who possesses such information or knowledge.
}

${ }^{10}$ Memorandum from Captain Robert Pereira to Jim Controvich, dated February 27, 1992. (See Appendix D.)

\footnotetext{
"See Appendix H, "Summary of Telephone Contacts," GE.
}

${ }^{12}$ Memorandum from B. N. Leach to R. E. Sojka, dated January 29, 1992. (See Appendix G.) The time that the exchange took place between VY and the fire department is not consistent with the records for the two organizations. VY control room logbook records show it received notification of the incident at 4:25 a.m. It in turn, called $B$. $\mathrm{N}$. Leach, who then called the fire department. Mr. Leach's memorandum states he believed he talked to the fire department at about 4:15 a.m. Fire Department records show the call taking place at 3:50 a.m. rial Incident ${ }^{13}$ allows the responders to call in additional resources to contain and mitigate the hazard. The upgrade was not communicated to the Springfield Police Department or other Springfield response agencies at this time. The fire department declared a Level II incident again, approximately 50 minutes later, allowing the police department to call in additional assistance for directing traffic.

At approximately 4:00 a.m., fire department personnel talked to an individual whom they believed worked for NRC. ${ }^{14}$ This individual stated that the shipping containers involved in the fire could withstand temperatures up to 3500 degrees Fahrenheit and that it was virtually impossible for these containers to fail under exposure to fire. He advised that the fire could be approached and fought in regular turnout gear.

The fire chief then moved closer to the scene of the accident to further assess the situation. The chief observed that the area was widely covered with diesel fuel and the fire was nearly out. Since there was concern about creating an environmental hazard by washing the fuel down the storm drains, as well as onto the area beneath the highway, at approximately 4:15 a.m. a decision was made not to fight the fire. The threat of thermal shock from cold water causing additional damage to the metal inner fuel containers was also considered in this decision.

At about 4:50 a.m., CHEMTREC was contacted by the Chicopee Police Department to obtain information for responding to an accident involving uranium dioxide. CHEMTREC read a definition from a chemical dictionary database to the police that described the material as a high radiation risk. The dictionary also listed uranium oxide as synonymous to uranium dioxide. CHEMTREC then telefaxed to the police department a Material Safety Data Sheet (MSDS) for uranium oxide that contained emergency response information.

GE informed the NRC Operations Center of the incident at 4:43 a.m. NRC then proceeded to notify the DOT National Response Center (at approximately 5:25 a.m.) as well as the Federal Emergency Management Agency (FEMA), Massachusetts Emergency Management Agency (MEMA), Environmental Protection Agency (EPA), Department of Health and Human Services, and the U.S. Department of Agriculture (USDA). NRC

\footnotetext{
${ }_{13}$ "City of Springfield Hazardous Materials Incident Response Plan," page 24. The need to declare a Level III Hazardous Materials Incident would have occurred if the incident had been beyond the capability of the city and local resources, or the incident had been anticipated to last longer than 24 hours; State and Federal resources would have been needed.

${ }^{14} \mathrm{NRC}$ does not employ anyone with the name the fire department gave. However, there is an individual with the same surname employed by the shipper, GE. The GE individual participated in conference calls with NRC, shipper, DOT, and the DOT National Response Center.
} 
contacted the Springfield Command Post at approximately 5:55 a.m. to offer assistance. The fire department reported that the fire was virtually out at this point. The NRC resident inspector from Vermont Yankee was in the Springfield area at this time, and proceeded to the scene to provide further assistance, as needed.

A VY representative arrived at the scene at approximately 5:30 a.m. and proceeded to survey the area for contamination. At 6:00 a.m. the survey was completed, and no radiation contamination was detected. At this time the fire was out, but the packages were still smoldering.

Several conference calls were held throughout the morning between NRC, DOT and State and local officials to discuss where the damaged containers could be sent until GE arrived and prepared them for a return shipment to its facility in Wilmington. After reviewing several options, State representatives decided to transfer the containers to the Westover Air Force Base (WAFB) in nearby Chicopee, Massachusetts. NRC participated in the discussions relating to the transfer of the damaged containers and supported the decision to use WAFB.

At approximately 3:00 p.m. the containers were transferred to WAFB. The damaged inner containers were bound with steel straps and repackaged in new wooden overpacks. On the morning of December of 18, 1991, the containers were returned to the GE facility without further incident.

\section{REVIEW OF EMERGENCY RESPONSE EFFORTS}

Review of the emergency response efforts undertaken during the Springfield accident focused on two major areas: organizational responsibility, and hazardous material and emergency response communications. These areas provide the setting in which the emergency response measures were taken and provide indications of where improvements might be made.

\subsection{Organizational Responsibilities in Emergency Response}

Because of the number of parties involved in responding to most accidents, it is essential that the roles of the various parties be well-defined and coordinated. ${ }^{15} \mathrm{Re}$ sponding parties should have established guidance or re-

\footnotetext{
${ }^{15}$ FEMA has developed guidelines for Federal, State, tribal and local officials to use in developing emergency response plans for transportation accidents involving radioactive materials. (See "Guidance for Developing State, Tribal, and Local Radiological Emergency Response Planning and Preparedness for Transportation Accidents," FEMA-REP-5, March 1983. A draft version of FEMA-FEP-5, Revision 1 , was published in July 1991.)
}

sponse plans that ensure that the primary responsibilities for emergency response to transportation accidents have been assigned, and that emergency response responsibilities have been defined and documented in writing. An emergency response plan should establish procedures to ensure that the proper parties are involved in the response, that adequate resources are made available, that required notifications and communications are made, and that there is a clear chain of command among responding parties. The following sections discuss the emergency response guidance or plans in place for each of the major responders.

\subsubsection{State and Local Authorities}

In practice, State and local authorities are almost always the parties providing the initial response to a hazardous material accident. The local and State authorities who provided the initial response to the Springfield accident included the MSP (Springfield Barracks), and the Springfield Police and Fire Departments. The Commonwealth Ambulance Service provided emergency medical services.

The initial response by these parties proceeded largely in accordance with the Springfield Emergency Response Plan (ERP) that the City of Springfield has in place for dealing with hazardous material incidents. ${ }^{16}$ The key elements of the plan invoked during the initial response included:

- Establishing an Incident Commander-the MSP who initially responded to the accident relinquished control to the Springfield Fire Department. The ERP calls for the first responding chief officer from the fire department to be designated the INCIDENT COMMANDER.

- Classifying the Level of the Event-In accordance with the ERP, the INCIDENT COMMANDER (fire department officer) declared the accident a LEVEL I incident. The level of the incident determines what resources are available and requires an assessment by the Incident Commander. The incident was later upgraded to a Level II incident.

- Establishing a Command Post-The INCIDENT COMMANDER established a command post from which important decisions could be coordinated.

These activities indicate that the lead responsibility was clearly designated, that the responders considered what resources were needed and acted to obtain those resources, and that the response was coordinated from a central location. The incident commander remained in

\footnotetext{
${ }^{16}$ "City of Springfield Integrated Hazardous Material Incident Response Plan," revised Feb. 28, 1990. (See Appendix F.)
} 
charge of the accident scene until the emergency phase was over. ${ }^{17}$

A critical decision, made during the emergency phase of response, was whether to extinguish the truck fire. Based on the hazardous material and emergency response information available during the accident and its training, the fire department decided not to fight the fire. (The hazardous material and emergency response information available during the accident and its impact on the fire department's decision are discussed in more detail in Sections 5.2 and 5.3.) The fire department used the "DECIDE Action Guide", for responding to hazardous material incidents, in arriving at its decision. ${ }^{18}$

The "DECIDE Action Guide" defines six key points for analyzing and responding to hazardous material incidents:
D - Detect hazardous material present.
E - Evaluate likely harm with no intervention.
C - Choose action options.
I - Identify the best options.
D - Do best option now.
E - Evaluate progress.

The fire department was able to "detect" the hazardous material present from the shipping papers. However, the fire department did not believe that it had sufficient information (from the shipping papers and Emergency Response Guidebook) to determine whether to fight the fire. The determination not to intervene (i.e., fight the fire) was based, in part, on the inconsistencies in emergency response information received during the accident and on several precautions listed in the Emergency Response Guidebook. The Emergency Response Guidebook, for example, states that runoff from fire control may cause water pollution, and that SCBAs and structural firefighter's protective clothing will provide limited protection. These precautions imply that there may be a risk to persons fighting the fire, and to the general public,

\footnotetext{
"The emergency phase (as used here) ended after the fire had burned itself out and the packages were surveyed and determined not to have released any radioactive material. The recovery phase began when the damaged shipping containers were loaded on trucks to be relocated to a temporary storage site.

${ }^{18}$ According to the DOT National Response Center, the "DECIDE Action Guide," which was developed by Lugwig Benner, is widely used in hazardous material incident response literature and training. It is specifically referenced in the Hazardous Materials Response Handbook published by the National Fire Protection Association. The Springfield Fire Department employs the "DECIDE Action Guide" in its in-house training.
}

from contaminated runoff. It should be noted that the accident occurred on a elevated highway that drains into the nearby Connecticut River.

At one point in deciding how to respond to the fire, the fire department asked a representative from VY, the intended receiver of the cargo, whether public safety would be endangered if the fire were not extinguished. The VY representative replied that there would be no threat to public safety outside an evacuation zone of 100 yards. The fire department then informed VY that since the fire was no threat to public safety where it was located, there would be no attempt to extinguish it, and that the fire department would wait until a team from $\mathrm{VY}$ arrived on the scene to evaluate the potential contamination problem. ${ }^{19}$ The fire department cited this interchange with VY as support that public safety would not be affected by its decision to let the fire burn out. In short, the fire department acted reasonably to protect public safety, consistent with its training and understanding of the emergency response information made available.

The Commonwealth of Massachusetts has identified its Department of Public Health as the lead State agency for responding to transportation incidents involving radioactive material. The Massachusetts Nuclear Incident Advisory Team (NIAT) serves as a support agency in responding to such incidents. ${ }^{20}$ Representatives from the Massachusetts Department of Public Health (MDPH) and from NIAT arrived at approximately 6:00 a.m. and conducted radiological monitoring of the accident scene and adjacent areas. NIAT continued to conduct radiological assessments during the emergency response and recovery phases.

The MDPH assumed responsibility for arranging to transfer the damaged shipping containers to a temporary site, where the containers could be inspected and repackaged in new outer wooden overpacks. Several sites in the Springfield and Chicopee areas were considered. MDPH selected WAFB, after consultation with Federal and local officials. ${ }^{21}$

\footnotetext{
${ }^{19}$ Memorandum from B. N. Leach to R. E. Sojka, dated January 29, 1992. (See Appendix G.)

${ }^{20}$ Massachusetts has an emergency response plan written specifically for radioactive material incidents. The lead agencies and responsibilities for dealing with radioactive material accidents are defined in the $\mathrm{Nu}$ clear Incident Advisony Team Handbook. The resources and capabilities of the Commonwealth in providing emergency response to radioactive material transportation accidents are further described in "Survey of State and Tribal Emergency Response Capabilities for Radiological Transportation Incidents," NUREG/CR-5399, Indiana University, November 1990.

${ }^{21}$ The Mayor of Chicopee later expressed concern, in a letter to the Chairman of NRC that he was not contacted about the storage of hazardous material at WAFB. The containers were transported through Chicopee en route to WAFB.
} 


\subsubsection{Federal Agencies}

In general, Federal agencies do not become involved in responding to transportation accidents unless specifically requested to do so by a State or local authority. ${ }^{22}$ In instances where Federal assistance is requested, the Federal government's role is primarily one of supporting the lead role of State and local governments. In most cases, the Federal role is limited to monitoring the event and providing technical information and assistance. FEMA, the U.S. Department of Energy (DOE), or EPA may provide coordination of Federal agency activities when two or more Federal agencies are requested to respond to an accident.

State and local governments can also request direct Federal help in monitoring and assessing the effects of a radiological transportation accident. ${ }^{23}$ In these cases, DOE has the lead Federal role for coordinating radiological monitoring and assessment until emergency conditions have subsided, at which time the lead Federal role is transferred to EPA. FEMA, DOE, and EPA were notified of the Springfield accident by the NRC Operations Center. DOE and EPA played no significant role in the response since their assistance was not requested. FEMA assistance was requested to facilitate the transfer of the damaged shipping containers to WAFB. However, FEMA was unable to provide timely assistance and the issue was resolved through direct contact with the base commander. The primary Federal agencies providing assistance during the Springfield accident were NRC and DOT. Their roles are discussed in the following sections.

\subsubsection{NRC}

NRC's role in responding to transportation accidents is defined in a general policy statement published in the Federal Register on March 29, 1984.24 As stated in the policy statement, NRC's primary responsibilities during a transportation accident are to:

1. Contact the designated State agency, as soon as practicable, to ensure that the agency has been informed of the incident;

\footnotetext{
${ }^{22}$ Some Federal agencies have statutory authority to respond to certain situations without a State request (e.g., situations involving nuclear weapons or occurring within specially designated areas). There was no statutory requirement for Federal agencies to respond to the Springfield, Massachusetts accident.

${ }^{23} \mathrm{DOE}$ has the capability for providing radiological monitoring and assessment, if requested. Response teams consisting of Federal and contract personnel are located at most DOE laboratories.

24"NRC Response to Accidents Occurring during the Transportation of Radioactive Material; General Statement of Policy," 49 FR 12335 , March 29, 1984.
}

2. Offer the State technical assistance, advice, and evaluations when the State is initially notified;

3. Make sure that DOE and other affected agencies are aware of the incident;

4. Maintain awareness of the situation until normal conditions are restored;

5. Provide information on packaging characteristics;

6. Ensure that the shipper (if an NRC licensee) provides complete and accurate information to emergency personnel; and

7. Provide recommendations to emergency response personnel on radiological issues, if requested by the on-scene coordinator or if a need is recognized by NRC personnel.

The responsibility to contact the designated State agency was not applicable in the Springfield accident since the State was aware of the incident before NRC. The Commission did offer, through its Region I Office and Headquarters, technical assistance, advice, and evaluations to the State during the incident and the recovery operations that followed. Communications among the State, shipper, Region I, and Headquarters were facilitated by conference call bridges established through NRC Headquarters Operations Center. Region I was the lead for NRC, with Headquarters providing technical information on the packaging. The first conference call was logged in at 5:00 a.m., on December 16, and subsequent calls were held frequently throughout the response. These calls helped ensure complete discussion of health and safety issues during decision-making.

At about 5:30 a.m., NRC notified DOE, FEMA, EPA, the Food and Drug Administration (FDA), USDA, and DOT. DOT regional personnel went to the accident site early. However, NRC did not interact extensively with DOT Headquarters until the second day of the incident, when the recovery operation was the primary issue.

GE declared the event as a Site Emergency early on Day 1 of the incident. A review of the licensee's emergency response plan does show that a transportation event, such as the Springfield accident, could be appropriately classified as a Site Emergency under its existing plan. However, the NRC Operations Center did not become aware of the classification until late in Day 1. The Site Emergency lasted approximately 3 days and 6 hours, until the shipping containers were returned to the GE facility.

Site Emergency classifications have specific meanings for fixed facilities such as reactors or fuel facilities. The use of the Site Emergency classification for an offsite transportation emergency is confusing. It may be appropriate to consider developing a standard classification for transportation emergencies. 


\subsubsection{DOT}

Carriers notify DOT of transportation incidents in which fire, breakage, spillage, or suspected radioactive contamination occurs involving shipment of radioactive material. DOT's Federal Highway Administration, Region I, staff went to the accident scene, and subsequently prepared a memorandum describing the circumstances and cause of the accident. DOT Headquarters was principally involved with the recovery phase of the accident and issued an exemption, under 49 CFR 107.113 , to permit the transportation of the damaged packages, under emergency conditions, to a nearby utility for temporary storage and repackaging before being returned to the shipper. State and local authorities later decided to transport the damaged fuel to the WAFB instead of the utility. NRC supported this decision. In choosing the new location, the need to revise the DOT exemption was overlooked, and the exemption was not revised to reflect the change in storage/repackaging site.

\subsubsection{Shipper}

The responsibility of the shipper is to know and comply with all applicable Federal, State, tribal, and local regulations pertaining to the shipment of radioactive materials. These responsibilities include:

- offering packages of radioactive materials in full compliance with the applicable DOT and NRC transportation requirements;

- $\quad$ supplying properly completed shipping papers; and

- providing a 24-hour emergency response number.

GE, Wilmington, NC (shipper of the unirradiated fuel involved in the Springfield, MA accident) used an appropriate package (RA-2/RA-3) for the shipment. The shipping container is certified as a Type AF container by NRC (NRC Certificate of Compliance No. 4986). The shipment was offered for transportation in compliance with applicable requirements, including properly completed shipping papers. The shipper also took an active role in preparing the damaged shipping containers for return to the GE facility in Wilmington, North Carolina. The shipper, however, was not prepared to provide timely emergency response information when requested.

\subsubsection{Carrier}

The primary responsibilities of a carrier during an accident are to notify local authorities, to ensure that a prompt response is initiated, and to ensure that emergency response information is available. The truck driver was able to retrieve the shipping papers from the truck $\mathrm{cab}$ and give them to a Massachusetts State trooper.

\subsubsection{Receiver}

The intended receiver of the shipment, VY, had no responsibility to respond to the accident, although the unirradiated fuel was being shipped to its facility. However, VY was contacted by emergency response personnel at the scene of the accident for information on fighting the fire. VY personnel responded to requests for information, dispatched a team to the accident scene, with detection equipment, and performed radiation surveys.

\subsection{Hazards Communications}

To respond effectively to hazardous material accidents, first responders must be able to determine what hazardous materials are involved. DOT regulations require shippers to communicate the hazardous nature of shipments through the use of shipping papers, the marking and labeling on individual packages, and by placards on the transportation vehicle. 25 A primary objective of these regulations is to enable first responders to identify the hazardous material by its proper shipping name, its United Nations (UN) Identification number, or its hazard class. The shipping name, identification number, or hazard class can be used to find emergency response guidance, for a specific hazardous material, from DOT's Emergency Response Guidebook. ${ }^{26}$

The shipment involved in the Springfield accident fully complied with DOT's requirements for marking, labeling, and shipping papers. In this case, the shipping papers were crucial in enabling the local fire department and police to identify the truck's cargo. As mentioned previously, the truck was not required to have a placard, and the labels on individual shipping containers were hidden by a tarpaulin covering the containers when the police and fire department first responded. Using the shipping papers, the police and firemen were able to determine the proper shipping name, RADIOACTIVE MATERIAL, Fissile, n.o.s, and material identification number, UN2918, for the cargo.

\subsection{Emergency Response Communications}

First responders often need additional information to determine or confirm their planned response during emergency situations. In recognition of this, DOT regulations require that certain emergency response information be provided in addition to the information required on the shipping papers. This information may be con-

\footnotetext{
${ }^{25}$ Requirements for shipping papers, package marking and labeling, and placarding are given in DOT regulation 49 CFR Part 172, Subparts $C, D, E$, and $F$.

${ }^{26} 1990$ Emergency Response Guidebook, DOT P 5800.5. DOT developed the guidebook for use by responders; it has been widely distributed to carriers and to State and local public safety authorities.
} 
tained directly on the shipping papers, or be included, along with the shipping papers, as a separate document. The required emergency response information must include the following:

1. Basic description and technical name of hazardous material;

2. Immediate hazards to health;

3. Risks of fire and explosion;

4. Immediate precautions to be taken in case of an accident or incident;

5. Immediate methods for handing fires;

6. Initial methods for handling spills or leaks; and

7. Preliminary first-aid measures.

DOT regulations also require that a 24-hour emergency telephone number be listed on the shipping papers. ${ }^{27}$

Additional emergency response assistance is also available from the Chemical Transportation Emergency Center (CHEMTREC). CHEMTREC provides 24-hour assistance to emergency responders, carriers, shippers, and other parties handling hazardous materials, via a toll-free telephone number. The Emergency Response Guidebook recommends that CHEMTREC be consulted to obtain additional emergency response guidance.

Information supplied by the shipper and responding parties shows that the shipper provided the required emergency response guidance and 24-hour emergency response telephone number for the Springfield shipment. The emergency response information was supplied by including a copy of Emergency Response Guidebook Guide 63 with the shipping papers. The shipping papers listed a telephone number at GE's fuel fabrication facility in Wilmington as the required 24-hour emergency response number.

The first responders were made aware of and used Guide 63 in determining how to respond to the truck fire. After initially consulting the guide and a hazard material database, CAMEO, the fire department called GE to obtain information that would clarify or confirm the recommendations given in Guide 63. The fire department also contacted the intended receiver for the cargo, VY in Vernon, Vermont. Based on the perceived inconsistencies between the guidance received from GE and VY and that

\footnotetext{
${ }^{27}$ DOT regulation 49 CFR 172.604 requires a 24-hour emergency response number which must be monitored at all times, and must be the number of a person knowledgeable about the hazardous material being shipped, and who has emergency response information for that material or has immediate access to a person with such information or knowledge.
}

given in Guide 63, and the lack of information in the CAMEO database, the fire department reaffirmed its initial decision to let the fire burn.

The Chicopee police also called CHEMTREC on behalf of the Springfield police and fire department. However, the call was placed too late, approximately 4:53 a.m., to have an appreciable impact on the decision to let the fire burn. Even if the call had been earlier, an examination of the data supplied by CHEMTREC indicates that it would not have been useful in responding to this event or in confirming the information given in Guide 63 .

Since the initial response was largely determined by the emergency response information received from the shipper, receiver, CAMEO, and DOT's Emergency Response Guidebook, these sources of information are discussed in more detail in the following sections. The emergency response information received from CHEMTREC is also discussed in Section 5.3.5.

\subsubsection{Emergency Response Guidebook}

The shipping papers were sufficient to allow the first responders to identify the material by its proper shipping name and locate the appropriate guidance (Guide 63) in DOT's Emergency Response Guidebook. (In this instance, the shipping papers actually included a copy of Guide 63.) However, there is some indication that the "generic nature" of the shipping name itself may have led to uncertainty in the initial response to the fire. Since the proper shipping name, RADIOACTIVE MATERIAL, Fissile, n.o.s, is used for all fissile radioactive material, it applies to materials with vastly different radiological hazards (e.g., unirradiated fuel (low-level radioactivity) and irradiated fuel (high-level radioactivity)). Guide 63 contains cautions against unshielded exposures, internal inhalation and ingestion, and contamination that are more appropriate to the hazards posed by highly radioactive materials, such as spent fuel. Therefore, Guide 63 may be misleading when used for fresh fuel shipments. ${ }^{28}$ It appears that the use of Guide 63 may have caused the responders to overestimate (or at least be uncertain of) the limited radiological hazards associated with fresh fuel. Because of this uncertainty, the responders decided to let the fire burn until additional guidance could be obtained.

\subsubsection{CAMEO}

After consulting Guide 63 , the fire department attempted to obtain additional guidance from CAMEO, a software package designed for emergency planning and life-saving response to chemical accidents. CAMEO was developed by the National Oceanic and Atmospheric Administration (NOAA) and EPA, with distribution and

\footnotetext{
${ }^{28}$ Especially in this instance, where the responders were not initially aware that the shipment contained fresh fuel.
} 
technical support provided by the National Safety Council. CAMEO contains over 3300 commonly transported hazardous chemicals, $60,000+$ synonyms for those chemicals, identification numbers, and labeling conventions. The system provides Response Information Data Sheets (RIDS) for a variety of chemicals, which specify fire and explosive hazards, health hazards, firefighting techniques, cleanup procedures, and protective clothing. CAMEO is currently in use in fire departments and hazardous material response units for responding to hazardous material accidents.

The Springfield Fire Department routinely uses the CAMEO in responding to hazardous materials emergencies. When the fire department queried CAMEO, there was no information available on uranium dioxide.

CAMEO currently has eleven chemical names for radioactive materials, and these names are similar to those found in DO'T's Emergency Response Guidebook. As with the Emergency Response Guidebook guides, CAMEO entries for radioactive material may be too broad to address specific types of radioactive material being transported.

\subsubsection{Shipper}

The Springfield fire department contacted the shipper, GE-Wilmington, at approximately 3:50 a.m., using the 24-hour emergency response number listed on the shipping papers. There are conflicting accounts on what advice $\mathrm{GE}$ gave the fire department during the initial call. Information submitted by the fire department suggests that GE advised it, at that time, not to fight the fire and to maintain an evacuation zone around the accident. GE believes that no "official" advice was given until the GE Manager for Nuclear Safety Engineering called back the Springfield fire department between 4:50 and 5:10 a.m. The advice given at that time was to put out the fire.

On either account, it does not appear that the 24-hour emergency response number was effective in assisting the Springfield Fire Department. The shipper required almost an hour to respond with its emergency response information. Meanwhile, the fire department believed it had received guidance from GE not to attempt to put out the fire. By the time the fire department received guidance from GE to fight the fire, it was too late to have an impact on the fire department's decision.

\subsubsection{Receiver}

VY, the intended receiver of the unirradiated fuel shipment, was contacted by the Springfield Fire Department at about 4:15 a.m. according to the station control room $\log$. A VY representative immediately returned the call to the fire department, was advised that the truck and cargo were on fire, and was requested to provide information on how to fight the fire. The VY representative responded that water could be used to extinguish the fire, but that precautions should be taken, including:

- use of full turn-out gear and SCBA for firefighters downwind of the accident;

- survey of firefighters and equipment;

- treatment of water runoff as contaminated.

The Fire Department also requested information on the hazards of letting the fire burn itself out. The VY representative responded that an evacuation of 100 yards around the fire would be adequate, and that there would be no hazard to the public from the radioactive material outside that area.

The response provided by VY, concerning cautions in fighting the Springfield fire, appear to agree with those provided in Guide 63. The VY cautions may have reinforced the impression, left by Guide 63 , that the material involved in the fire posed a significant radiological hazard. For example, Guide 63 states, under the heading "Health Hazards", that runoff from fire control or dilution may cause pollution. Controlling the runoff water in this incident would probably have been a difficult operation and, according to Guide 63 , could have led to potential contamination and exposure. The progress of the fire, potential difficulty in complying with firefighting precautions, and the simplicity and low-hazard assessment of the noaction option appear to have contributed to the fire department's decision to let the fire burn.

\subsubsection{CHEMTREC}

The Chicopee police called CHEMTREC at approximately $4: 53 \mathrm{a} . \mathrm{m}$. to request assistance in responding to an accident involving uranium dioxide. (The shipping papers describe the cargo at one point as enriched solid uranium dioxide.) CHEMTREC's initial response was that there was no information available on uranium dioxide in the optical storage and retrieval database. ${ }^{29}$ CHEMTREC was, however, able to provide the Chicopee police with information on uranium dioxide from the Condensed Chemical Dictionary. The Condensed Chemical Dictionary stated that uranium dioxide has a "high radiation risk" and ignites spontaneously in finely divided form. The Condensed Chemical Dictionary also listed uranium oxide, uranic oxide, urania, and yellowcake as synonymous to uranium dioxide. The initial contact closed with CHEMTREC promising to call back the Chicopee police if any additional information became available. CHEMTREC followed up on the initial call at approximately 5:02 a.m. when it telefaxed an MSDS on uranium oxide, yellowcake, to the Chicopee police.

\footnotetext{
${ }^{29}$ CHEMTREC Report Number 11838, dated 12/16/91. (See Appendix I.)
} 
The information received from CHEMTREC was not useful in determining whether to fight the fire. The information was requested at a point when the decision to let the fire burn had become irreversible. By 4:53 a.m. the fire had been burning for about $1 \frac{1}{2}$ hours and the fire department had decided that using water on the shipping containers might induce additional damage from thermal shock. However, even if the information had been requested earlier, it is doubtful that it would have been useful in responding to an accident involving a shipment of fresh fuel rods. The information provided by CHEMTREC (which was for uranium oxide or yellowcake) was not consistent with the guidance given by the shipper and receiver.

DOT permits shippers to use CHEMTREC to fulfill their requirement for a 24-hour emergency response number. Potential advantages of using CHEMTREC in this manner are that the emergency response information from the shipper and CHEMTREC would be identical, and that CHEMTREC has knowledgeable staff on duty 24 hours a day. The disadvantage is the cost. Even if shippers did not want to undertake the cost of using CHEMTREC as a 24-hour emergency response number, they should consider supplying emergency response information to CHEMTREC on the hazardous materials they ship. This should ensure that CHEMTREC has available appropriate emergency response information for the specific materials being shipped.

The availability and timeliness of accurate emergency response information is important not only to first responders but to the public as well. During the Springfield event, CHEMTREC was contacted by a major wire service for information on the material involved in the accident. The wire service was also given the information, from the Condensed Chemical Dictionary, that uranium dioxide posed a high radiation risk. When this information was subsequently used in the news media, many in the public may have been unduly alarmed.

\section{SUMMARY - LESSONS LEARNED FROM THE SPRINGFIELD ACCIDENT}

The emergency response efforts during the Springfield accident involved the concerted activities of numerous local, State, Federal, and private parties. In general, each of these parties responded in accordance with established guidance and emergency response plans. Required notifications and communications were made, and there was a clear chain of command among the responding parties. In short, the mechanism in place for responding to emergencies worked.
Key decisions made during the response were influenced by the emergency response information received during the accident, and quite possibly from the lack of adequate survey equipment. The responding parties did not believe that the emergency response information received from the various sources was consistent. In addition, the first responders may have been unable to accurately determine the radiological risk from the shipment because their equipment was outdated and may not have been calibrated. This could have contributed to the decision not to fight the fire. However, it should be noted that first responders are not practiced in the use of radiological survey equipment and should not depend on survey equipment to determine their response.

On January 13, 1992, a critique of the response to the December 16, 1991, accident was held at the Springfield Fire Center. ${ }^{30}$ Representatives from local, State, and Federal agencies involved in responding to the incident participated in the critique, which was moderated by the City of Springfield Office of Emergency Preparedness. ${ }^{31}$ The representatives discussed issues that arose as a result of the incident and made recommendations for improvements. Selected issues and recommendations are discussed below.

One issue raised by the fire department was whether their 1950s Civil Defense monitoring devices were adequate for the response. The discussion indicated that there is considerable variability in radiological-monitoring-equipment maintenance and calibration practices among the agencies represented. There was agreement that modern equipment would provide greater assurance to emergency responders.

The MSP concluded that the incident was an example of the importance of up-to-date reference material, and that if sufficient information had been available to the fire department on a more timely basis, the truck fire could have been extinguished instead of being allowed to burn. The MSP also suggested that it would be helpful if it

\footnotetext{
${ }^{30}$ Report dated January 29, 1992, Captain Robert J. Bradley, MSP.

${ }^{31}$ Agencies represented included:

Springfield Fire Department

Springfield Fire Commissioner

Springfield Police Department

Springfield Department of Public Work

Springfield Office of Emergency Preparedness

Commonwealth Ambulance

Massachusetts Nuclear Incident Advisory Team

Massachusetts Department of Environmental Protection

Massachusetts Emergency Management Agency

U.S. Nuclear Regulatory Commission

U.S. Department of Transportation

U.S. Occupational Safety and Health Administration

Federal Emergency Management Agency

Vermont Yankee Nuclear Power Station

Baystate Medical Center

Monsanto Chemical Company (observer)

Massachusetts Legislature (observer)
} 
received additional training in the recognition of nuclear material packaging.

The Springfield Police Department indicated that since the fire department had declared only a Level I situation initially, the Police Department was unable to call in additional personnel for traffic control and related duties. Further, when the fire department did upgrade the incident to a Level II status, the upgrade was not communicated to the police department. Most of the issues discussed at the January 13, 1992, meeting involved improvements in communications, equipment, or procedures. Most of these improvements can be implemented at the local and State level. A notable exception is the need to improve hazardous material and emergency response information. A more detailed discussion of the issues is contained in Appendix C.

In addition to the issues identified at the meeting, NRC has identified the following additional items for consideration:

\section{Emergency Response Organizational Responsibilities}

1. NRC does not have an adequate classification standard for categorizing transportation accidents. GE declared the Springfield event as a "Site Emergency." This classification is confusing since it does not have the same meaning as a site emergency for a fixed facility. Consideration should be given to developing a standard classification, for transportation events, that has its own terminology.

2. State agencies have the responsibility for directing emergency response activities. As part of this responsibility, they should keep local officials informed of decisions affecting their jurisdictions. The responsibility to notify local officials should remain with the State.

\section{Hazardous Material and Emergency Response Communications}

1. Use of the 24-hour emergency response number listed on the shipping papers was not effective. Although a recommendation to fight the fire was eventually provided to the responders, it was received too late to guide response actions. DOT regulations require that the person monitoring the number either be knowledgeable, or have immediate access to a person who has knowledge, of comprehensive emergency-response and incident-mitigation measures, and be responsible for providing detailed information concerning the hazardous material. Shippers need to ensure that they can promptly satisfy this requirement at any hour. ${ }^{32}$

2. Emergency Response Guide 63 may not be appropriate for responding to transportation emergencies involving unirradiated (fresh) fuel. Because this guide is used for all fissile materials, it is quite broad in scope, providing cautions against the more highly radioactive fissile materials (i.e., spent fuel). These cautions, however, may not be appropriate for lowlevel fissile materials, in that they may cause first responders to overestimate the limited radiological hazard associated with these materials. Alternatives to assigning all fissile materials to Guide 63 should be considered, including assigning low-level fissile materials to a different guide, or developing additional guides that more closely address the hazards of different fissile materials.

3. In general, the emergency response guides in the 1990 Emergency Response Guidebook may be too generic. All radioactive materials, other than a few uranium and thorium compounds, ${ }^{33}$ are grouped under nine DOT proper shipping names. ${ }^{34}$ Five of these proper shipping names carry the descriptor "n.o.s", or "not otherwise specified." The emergency response guidance for the numerous materials classified under the nine shipping names is contained in just three guides, Guides 61,62 , and 63 . Consideration should be given to the possibility of using packaging type and end use in assigning DOT shipping names to radioactive material cargoes. The use of packaging type may be appropriate since radioactive material is the only category of hazardous materials with the shipping packaging designed to meet hypothetical accident conditions.

4. CHEMTREC was not able to provide appropriate emergency response information for uranium dioxide. Although the information received from CHEMTREC did not play an important role in determining the initial response to the Springfield accident, it could play a significant role in future accidents. The 1990 Emergency Response Guidebook,

\footnotetext{
3249 CFR 172.604(a) and (b).

${ }^{3}$ They are THORIUM METAL, pyrophoric; THORIUM NITRATE; solid; URANIUM ACETATE; URANIUM HEXAFLUORIDE, fissile; URANIUM HEXAFLUORIDE, non-fissile; URANIUM HEXAFLUORIDE, low specific activity; URANIUM METAL, phrophoric; URANIUM NITRATE HEXAHYDRATE SOLUTION, URANYL NITRATE, solid; and URANYL ACETATE.

${ }^{34}$ The proper shipping names are: (1) RADIOACTIVE MATERIAL, empty package; (2) RADIOACTIVE MATERIAL, excepted package; (3) RADIOACTIVE MATERIAL, instruments and articles; (4) RADIOACTIVE MATERIAL, articles manufactured from natural or depleted uranium or natural thorium; (5) RADIOACTIVE MATERIAL, fissile., n.o.s; (6) RADIOACTIVE MATERIAL, limited quantity, n.o.s; (7) RADIOACTIVE MATERIAL, low specific activity, n.o.s; (8) RADIOACTIVE MATERIAL, n.o.s; and (9) RADIOACTIVE MATERIAL, special form.
} 
which is widely disseminated to fire, police and other emergency response organizations, advises first responders to call CHEMTREC for emergency response information on hazardous materials. Shippers of radioactive material should be aware that CHEMTREC may not have emergency response information on the materials they ship and should consider supplying appropriate emergency response information to CHEMTREC.

5. CAMEO, the hazardous materials database used by the Springfield fire department, did not contain any information on emergency response measures appropriate for accidents involving uranium dioxide. As with the Emergency Response Guidebook, CAMEO entries for radioactive materials may be too broad to address the specific hazards of the wide range of materials being transported. Consideration should be given to adding emergency response information to the CAMEO system for radioactive materials. 


\section{APPENDIX A}

\section{Shipping Papers}


GEMERAL ELECTRIC

Min vinctow, NC 28402

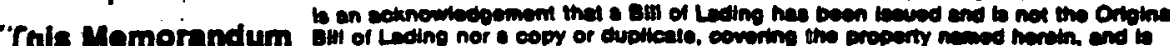

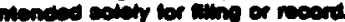

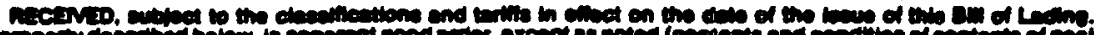

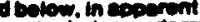

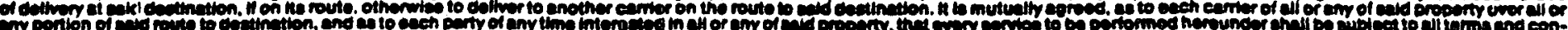

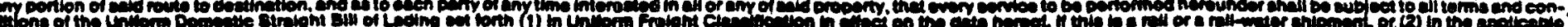

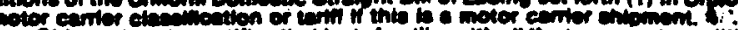

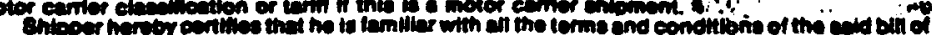

Coverones:

VERMONT YANUEE MUCLEAR POMER STATION

VEANONT YANIKEE NUCLEAR PONER CORO

VERNON, VEAMONT

COATACT: Y.P. BOAOIT OR GREG WAILOR $8-802-257-7711$

camatrañIE

Carster

$\div$ maser

Traller Listor

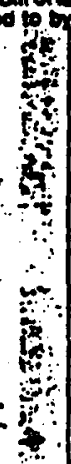

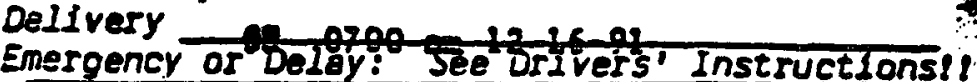
OUWIIT, DEBCAPTON AND IOENTACATON OF ARMCLES

+2000 \&TEEL BOXES. WWOIB RAOACTIVE MATERIAL, FISSILE, N.OSS:

TOTAL QUANTITY:

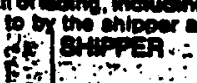

s.t.

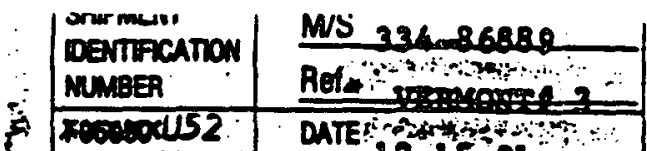

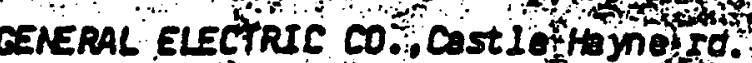
Winlnoton Narth Cerollna 28401

$\therefore$ Far:Fralont Poument Sand

A.0riolnal krelont bII

B. Copy of" thi ary of lading

$7 f$

r.t.

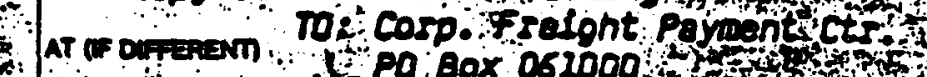

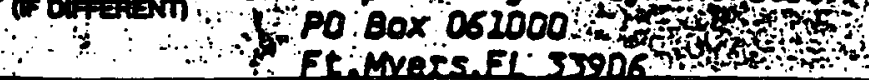

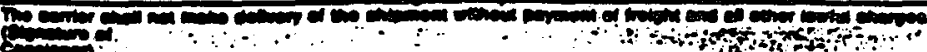

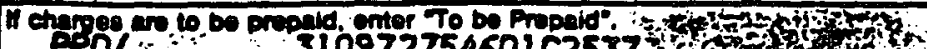
31097275460202537 ist

ACTIVTY PER PKG:

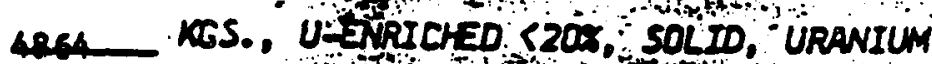

FUERGENOY CONTACT:

$+4$

He:

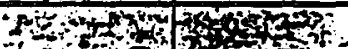

HAZARO LAEELS ON PKG: RADIOACTIVE

TRAYSPORT INDEX PER PKG: dEFEer, TOTAL

NRC PKG CERT NO./IAEA PKG IDENT NO.: HSA/4986/AF, PKC MOCEL RA-2/RA-3

PKG IS FISSILE QASS I,

PLACARDS: NONE REQUIRED

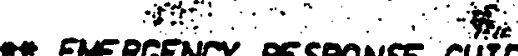
int:

Hons a

IDEBOOK: Guldet

ath

ORIVER'S INSTRUCTIONS: TEAM REQUIRED: $\square$ YYS $\square$ No

-DO NOT ARRIVE AT DESTINATION MORE THAN 2 HOUR PRIOR TO ESTAEISHEO OEL IVERY

TIAE STATED ABOVE URLESS AUTHDRIZED BY GE-TRAFFIC (CALL YOUR OISPATCHER FOR

APPROVAL I.

int:

- CARRIER SHALL MAINTAIN CONTROL OF SHIANENT UNTIL RECEIPT OY CONSIGNEE TA

-ANY CONDITION WHICH MAY CAUSE OEVIATION TO ABOVE REQUTRED OELIVERY TINE, ORY

-IF EMERGENCY, ACCIOENT, THEFT, OA THREAT OF. THEFT, DRIVER (PR OISPATCYERI MUST.

CALL GENERAL ELECTRIC IMAEDTATELY:

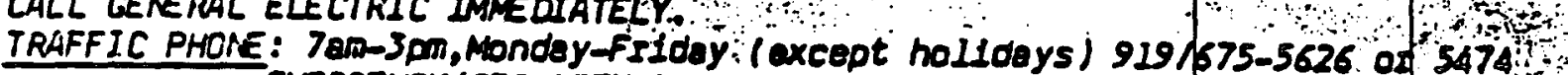

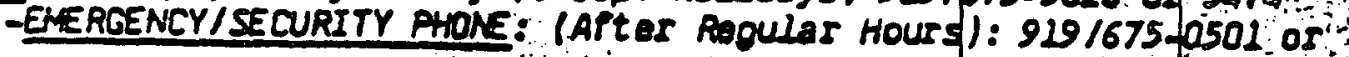

CARRIER/ORTVR STATENENT: I have slead and understand the above Instructions.

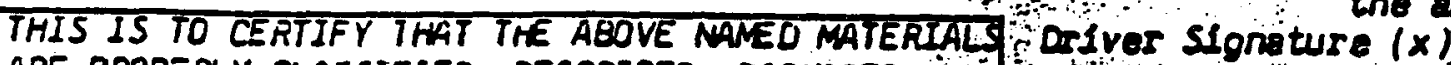
ARE PROPERLY CLASSIFIED, DESCRIBED, PACKAGEO, HARKED ANO LADELED AND ARE IN PROPER CONDITION: FOR TRANSPORTATION ACCOROING TO THE APPLICABLE: REGULATIONS OF THE OEPARTMENT OF TRANSPORATION. SIGNATURE

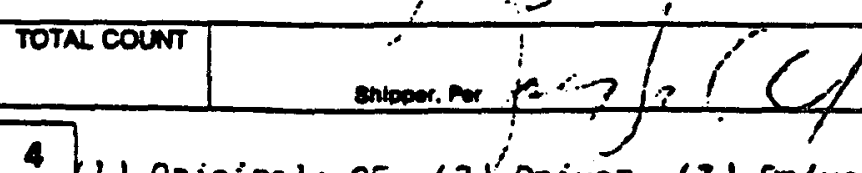
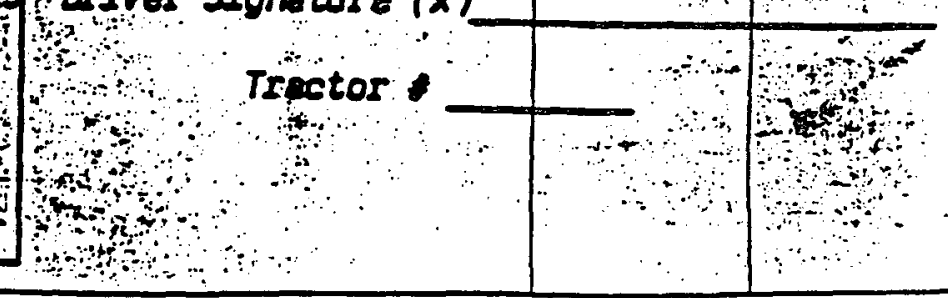

4 (1) original: Ge (2) ariver

(3) criver "Bidling copy"

Anem, Por

TOTAL WEIGHT

(4) Consignee 


\section{APPENDIX B}

\section{Accident Investigation Report}

U.S. Department of Transportation

Federal Highway Administration 


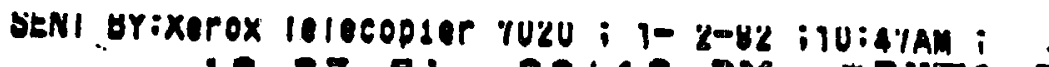

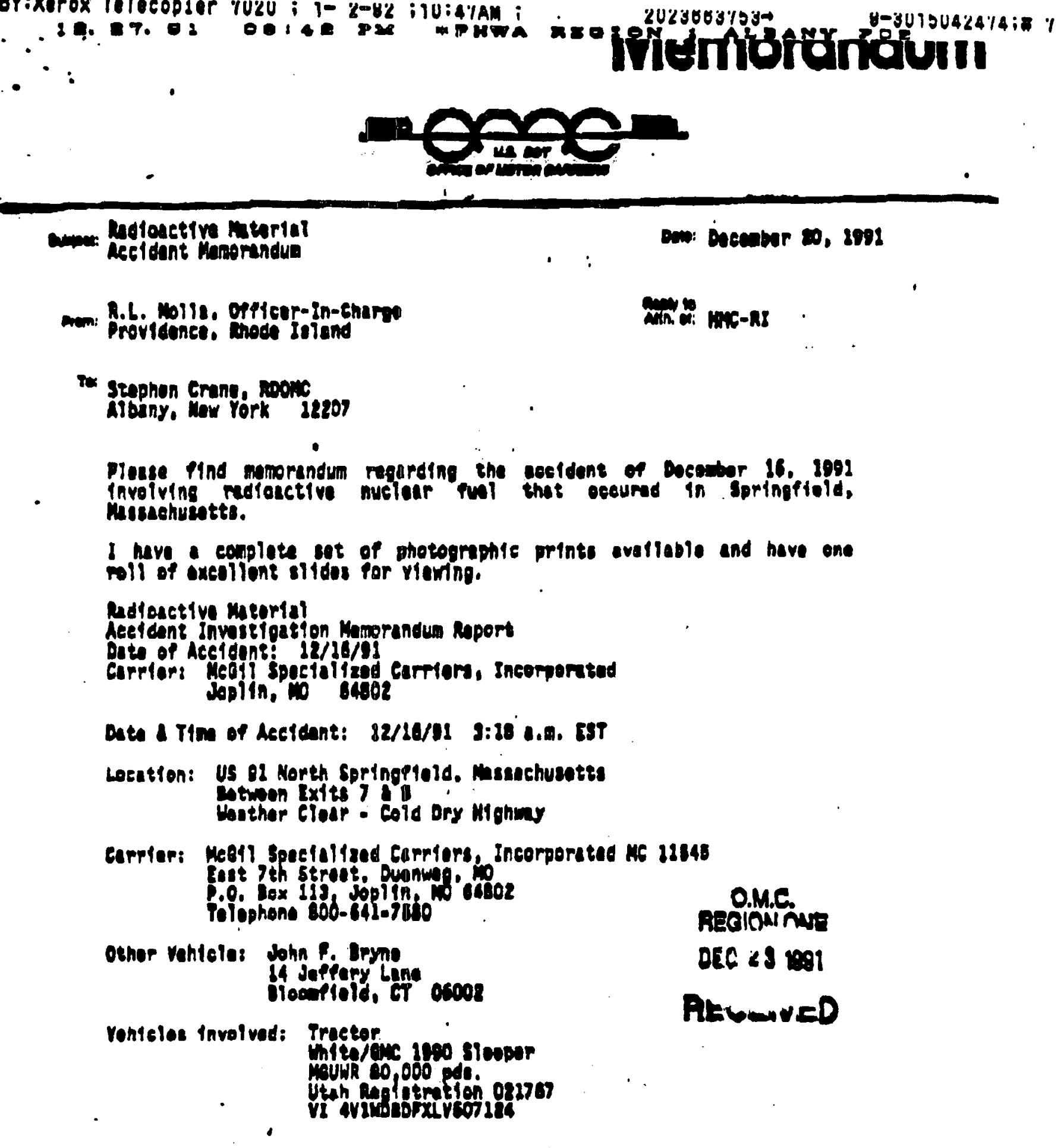

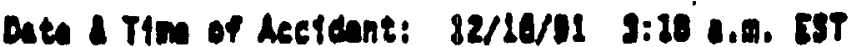

Location: US 92 North Springplold. Mesechueates

cotroen Exits 780

tasthar Clear - Cold Ory Mighing

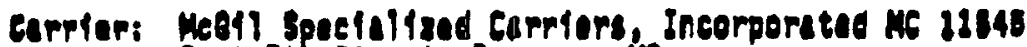

Eact ith stroct. Dunwey. In

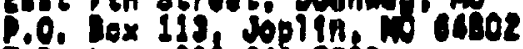

Plophone cob-c14-7tio

orhar Vohicles John $F$. Iryne

14 Japfery Lane

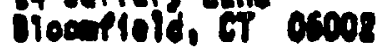

Vonisloe Involvad: Proctor.

Trite/enc 1400 sicosar

multr 00,000 ods.

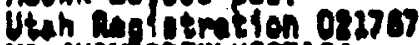

vi avinoforxiveoride

\section{ome \\ Realouinue \\ Dec es $\mathrm{mi}$ \\ Pltumed}




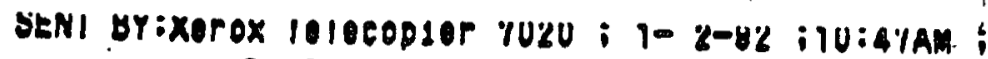

24. 87. 02 (0.48

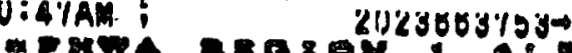

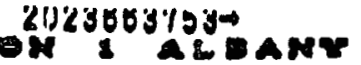

y-3uTPU42414is

Somf - Trutler

Fontein ind prot ad

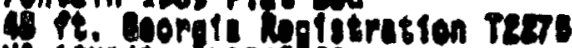

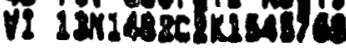

Dasangear Yahrelor

2903 Poyoes roreol, 2 coor

GT Ropituration lof in

it Jisis20030207021

Drivoral Commorefal Vohfele

Jepoph P. Ounn - oog o4-23-33

78 torthest weh strut

ontahema city. Okiohow 73124

Lfcence Nuber oxs10 24177)

Sentus - Comingetol Liesnso

(No col stetus)

Paseanger Vohteles Lein P. Drmo dos o7izï/ss

IA Jupifory Lene

Iloonfield, et Oc002

Iteense Muber - CT I04264728

Patalfeton wour

Injuriass Throe (3)

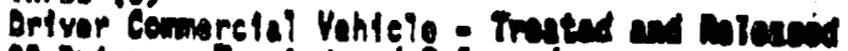

Co orivor - Truted and Wicaced

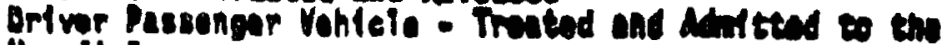
Maritel

Gargor Mazerdous Matarlal

Thive (28) - Wod a stan boxek containing totel gravity

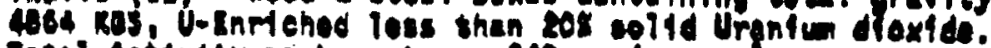

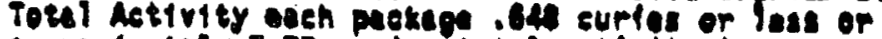

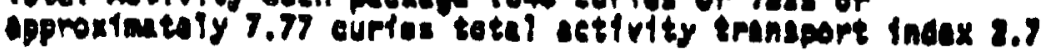

Heardous Matorfall Use/soms/ar

Peckesines Package - Presfle Glase I

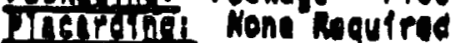

sale ettached onfpoing cosimants

Proparty Damage: Extansive dot to the

Acetdent and Fire

Entimitis on de/20/0d to be in exeass of $1000,0000.00$

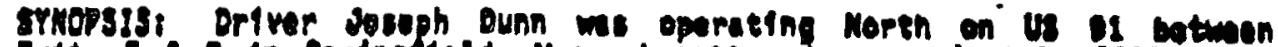

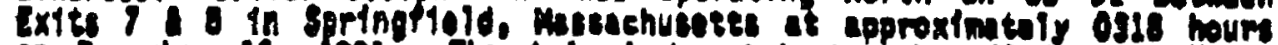

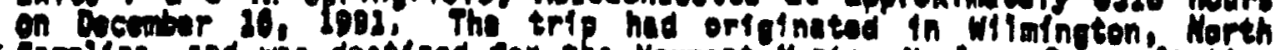

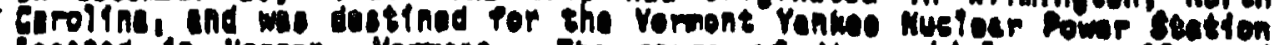

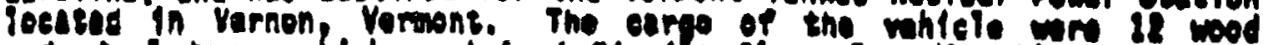

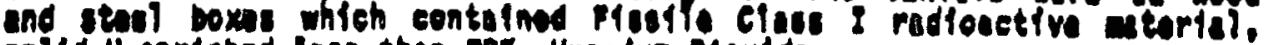

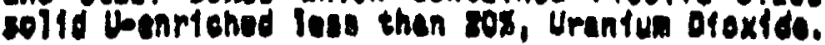




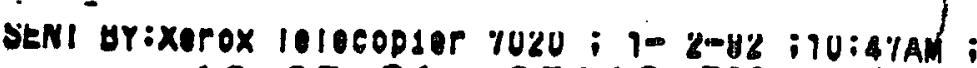

28,.

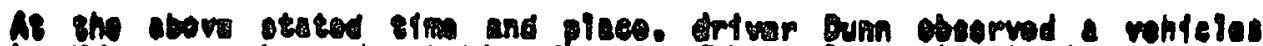

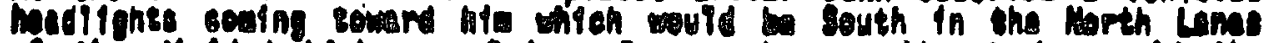

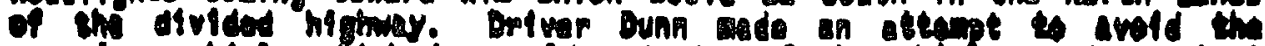

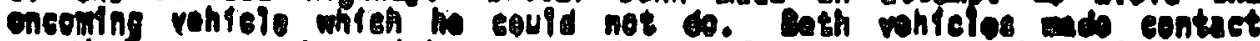

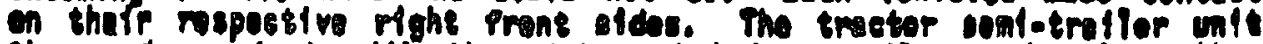
then Bade ophtagt wes tho rightnand opldge rall and barplop. than

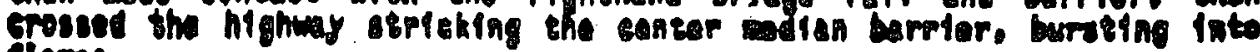
Plame.

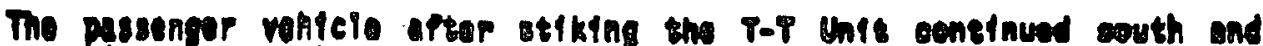

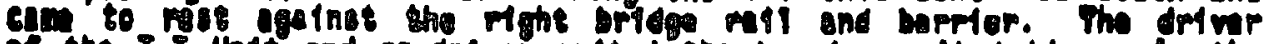

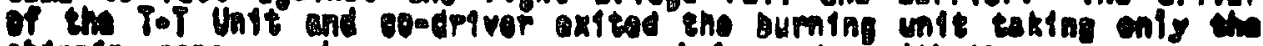

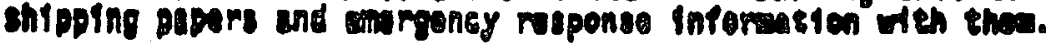

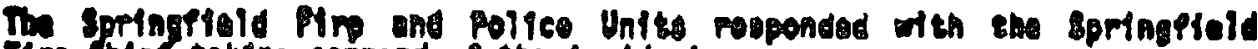
Pir chiaf texting eoming of the inefonts.

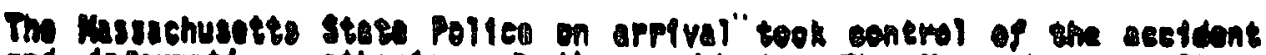

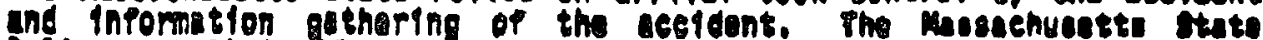

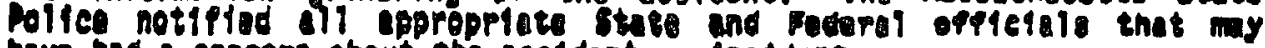
mu and conearn bout th reeident or inoidens.

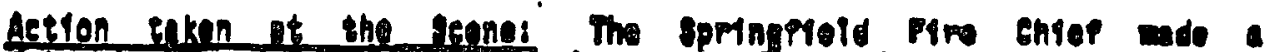

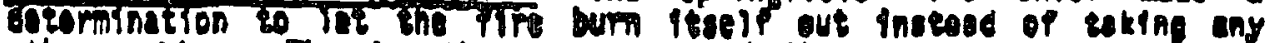

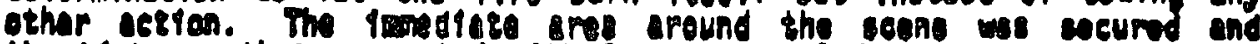

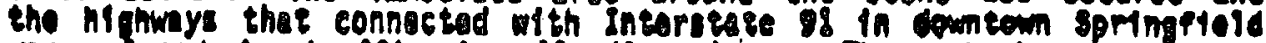

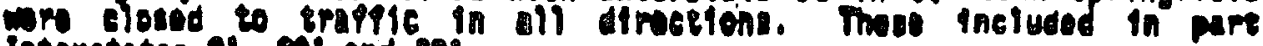
Intemtetes 81.801 and 291.

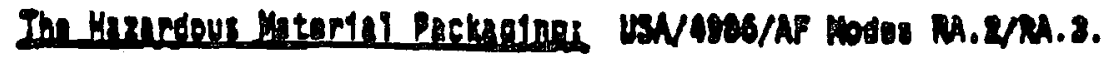

The Ixtomal wod casing bumed completely. The Imner catal eontainer beease difeortad and in sow arees appered to have bumad shrough.

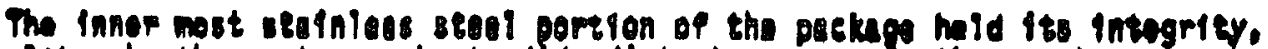

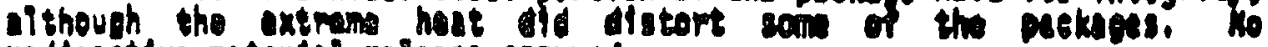
molosetive atepial poloase cesured.

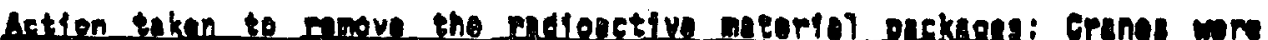

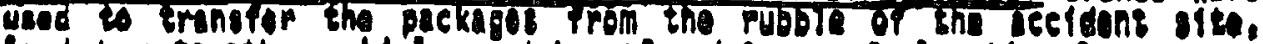
loadod on 80 other vahteles and transforcd to a cape location for

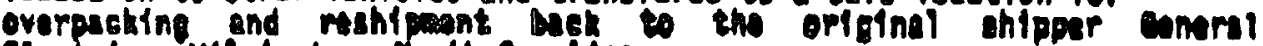
Bloctrie, wielngton, Horth carithe.

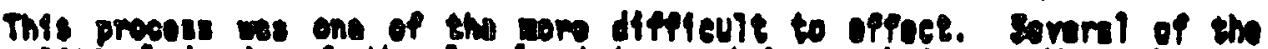

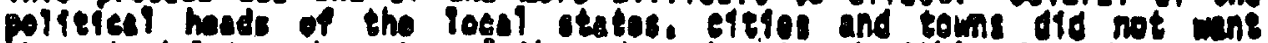

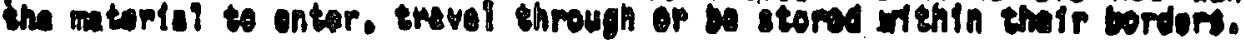

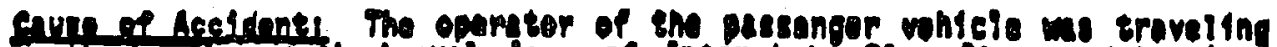

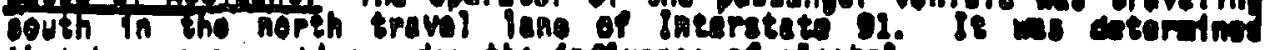
thet we operating udep the influnse of cleohol. 


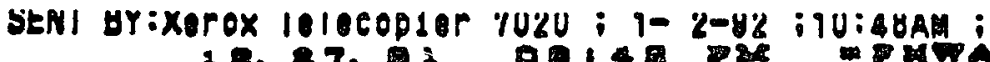

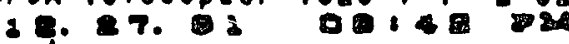

20236631539

$. \quad .+1 \cdot$

ganelunsensu

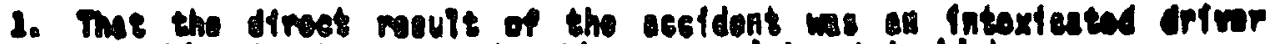

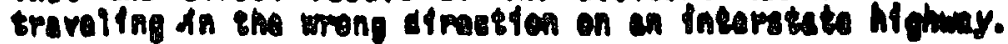

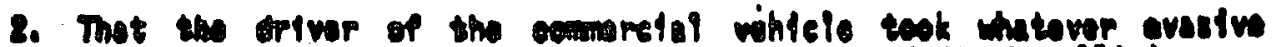

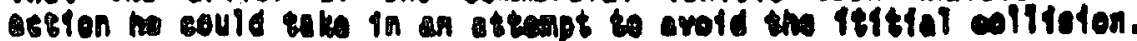

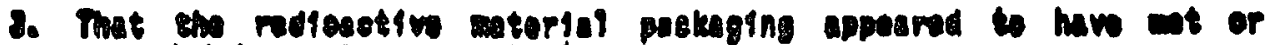
oxcendod 18s sufaty axpesestens.

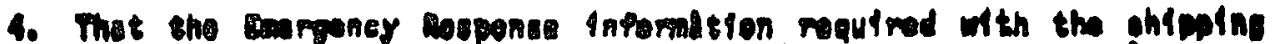

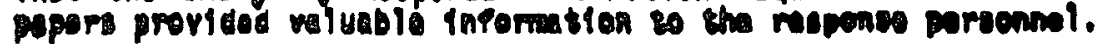

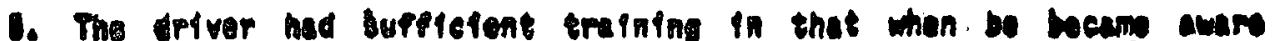

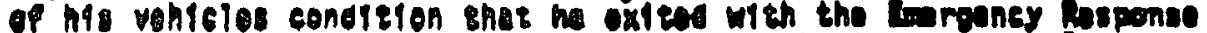
insormation and shipping pars, and provtded tham to kaspones perennel.

conithst

1. Altheugh the opfrep opovided the onfpping papars to respense

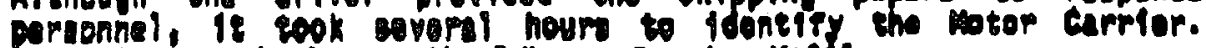
the oniy deseripetion on the o/h wa cerpier meali.

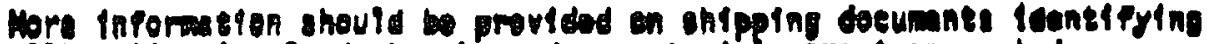

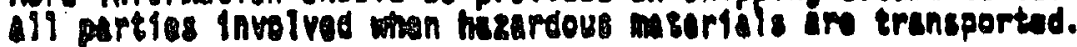

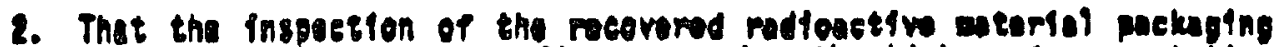
and proparoston orior to it pe-entering the highway transportation. oystem wovid have been within the critarle of mosh section 18(a)(8).

Attachents:

Photeprephe

chlpolng Docusane

Packege spoclpqeasions

Mowepisar Moports 


\section{APPENDIX C \\ Accident Investigation Report}

Massachusetts State Police 

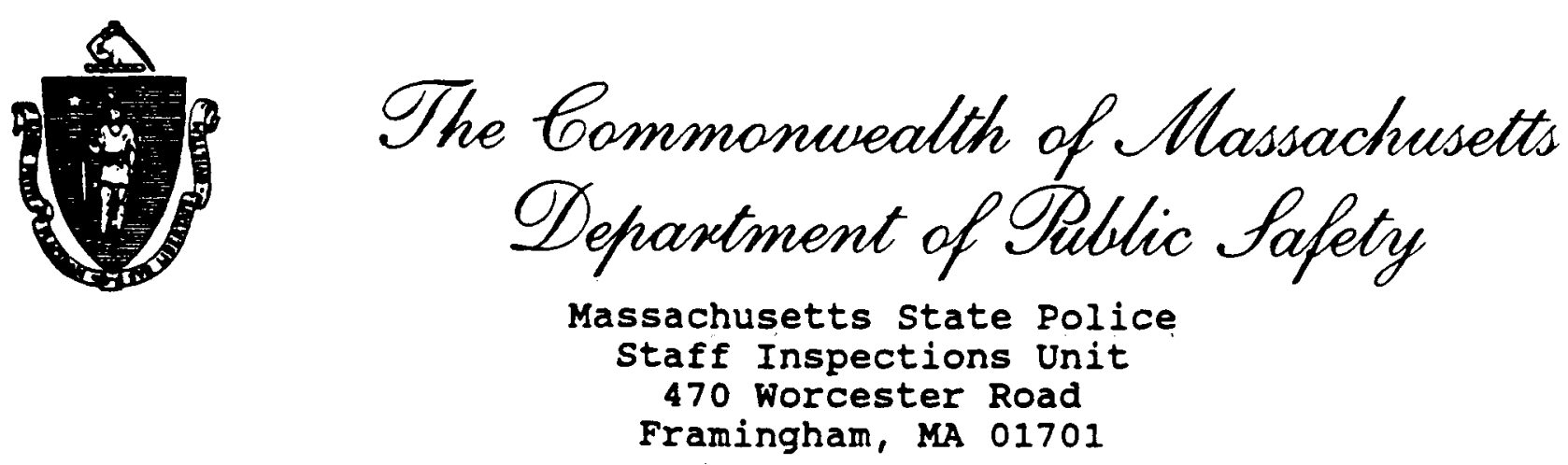

January 29, 1992

To: Colonel Charles F. Henderson, Deputy Superintendent Lt. Colonel Thomas J. Kennedy, office of StaffOperations

Lt. Colonel Edward J. Cronin, office of Field operations

From: Captain Robert J. Bradley, Staff Inspections Unit

Subject: After-Action Report and Analysis of Nuclear Material Transportation Accident, Route 91 Springfield, Massachusetts on December 16, 1991.

1. In the early morning hours of December 16, 1991, a 1990 GMC Tractor with flatbed trailer, operated by Joseph P. Dunn of 2603 East 88th Street, Tulsa, Oklahoma, and owned by McGil Specialized Carriers, 1425 Franklin Road, Marietta, Georgia, was operating north on Route 91 in springfield, Massachusetts. The truck was transporting 4864 kilograms of $20 \%$ solid uranium dioxide from the General Electric Company, Castle Hayne Road, Wilmington, North Carolina to the Vermont Yankee Nuclear Power Station in Vernon, Vermont, to be used as fuel in the Vermont Yankee atomic reactor. The uranium dioxide, a Fissile class I material, N.O.S. UN 2918, consisted of small pellets encased in metal fuel rods. The fuel rods were enclosed in 12 metal boxes known as casks, protected by a wooden packing case as required by Federal regulations.

2. At approximately 0315 hours, at the 5.7 mile-marker northbound, the driver of the tractor-trailer observed a white Toyota Tercel owned and operated by John F. Byrne of 14 Jeffrey Lane, Bloomfield, Connecticut, travelling south in the northbound lane, on a collision course with his truck. Despite evasive action by both operators, the tractor-trailer struck the passenger side of the Toyota, jackknifed, and hit the jersey barrier on the east side of the roadway. After impact with the barrier, the truck rebounded across the highway, striking the guard rail on the west side of the northbound lane, where it came to rest. The impact with the 
cab of the tractor. The Toyota, after impact, struck the jersey barrier on the east side of the northbound lane, coming to rest facing south against the barrier.

3. At 0318 hours, numerous reports of the accident were received at the state Police springfield sub-station. Troopers Brojan and Sanford were dispatched to the scene. At 0324 hours, Trooper Brojan contacted SP Springfield requesting that the springfield Fire Department and an ambulance respond to the scene. At 0326 hours, after being advised of the nature of the cargo by the tractor-trailer operator, troopers at the scene notified sp springfield that the truck was carrying nuclear material. This information was immediately transmitted to the springield Fire Department. State Police personnel closed Route 91 , and established an isolation zone at the scene. The injured parties were transported to springfield Hospital for treatment, and the operator of the Toyota, John F. Byrne, was subsequently arrested by Trooper Brojan for: 1. Operating Under the Influence of Alcohol, 90-24, 2. Operating to Endanger, 90-24, and 3. Violation of one Way Traffic, 89-10. opon the determination that hazardous meterial was involved, the statutory responsibility for command of the entire incident evolved to the Chief of the springfield Fire Department.

4. By the time sufficient information on the nature of the nuclear material and its threat to emergency responders and the community could be ascertained, the trailer and its contents of nuclear fuel was totally involved in fire. The Springfield Fire Department made the determination to let the trailer and its contents burn out. Incident operations at this time took a defensive posture, concentrating on such issues as perimeter and isolation zones, and the re-routing and management of traffic. Subsequentiy, many other issues and concerns would present themselves to the twenty six Federal, State, local, and private sector participants involved in this incident during its 13 hour and 37 minute duration.

5. This report consists of three sections: a Chronology of Events and Actions, the results of a critique by Participating Agencies held at the springfield Fire Academy on January 13, 1992, and Issues of Concern and Recommendations for Future Improvement. The Chronology of Events and Actions has been constructed from the various reports submitted on this incident, the Daily Administrative Journals of General Headquarters, Boston, Troop "B" Headquarters, Northampton, and SP springfield, as well as this officer's personal knowledge. State Police reports utilized were those of Major C.N. Appleton, Captain J.M. 
Sheehan, Sergeants M.A. Lapointe and G.E. Chaisson, Commercial Vehicle Enforcement Unit, Sergeant D.J. Kennedy, and Trooper J.E. Gura. Also incorporated were the reports of the following members of the Springfield Fire Department: Acting District Fire Chief R.A. Pereira, Lieutenants A. Amato, J.F. Friberg, and D. Larson, as well as the reports of Commonwealth Ambulance Dispatch, Unit 38 , and Unit 60 , and the draft report on the overall incident prepared by James $T$. Controvich, Director of the City of Springfield office of Emergency Preparedness. No reports were available from the Springfield Police Department. Daily Administrative Journal and dispatch entries provided the most accurate chronological data. In cases where events and actions were not documented in specific chronological terms, their times were estimated, utilizing the various reports and known times as standards. There also appeared to be a deviation in time between the clocks utilized by SP springfield and those used by the Springfield Fire Department.

6 .

CERONOLOGY OF EVENTS AND ACTIONS

December 16, 1991

0318 SP Springfield receives reports of a motor vehicle accident involving a tractor-trailer unit and car, Route 91, northbound lane at 6 mile-marker, Baystate West. Tprs. Brojan and Sanford assigned.

0324 Tpr. Brojan requests ambulance and Springfield Fire Department - Truck cab on fire and 3 parties injured - springfield Fire and Commonwealth Ambulance (contract provider for the city of Springfield) contacted by SP springfield.

0324 Commonwealth Ambulance dispatches Units 38 \& 60 to accident scene, Route 91, Springfield.

0324 Springfield Fire Department dispatches Engine company 7 to accident scene, Route 91, Springfield.

0326 Troopers Brojan and Sanford advise that the tractor-trailer involved in the accident is carrying radioactive material - MSP Commercial Vehicle Enforcement Unit requested at scene. springfield Fire notified of radioactive material on truck.

0326 Route 91 closed in both directions by state Police personnel. 
0326 Engine Company 7 advised of radioactive cargo and decides to stage at Boland Way due to potential hazard. Lt. Larson, Company officer of Engine Company 7 declares a Level I mazxar situation. Springfield Fire Department dispatches Ladder 1 (Group B), Rescue squad, and HAZMAT truck to accident scene, Route 91, Springfield.

0330 BHQ desk contacts sgt. MA Lapointe, Commercial Vehicle Enforcement Unit, re Route 91 accident. Sgt. Lapointe contacts Tpr Ahearn, CVEU, to report to scene.

0332 Commonwealth Ambulance Units $38 \& 60$ arrive at scene.

0335 Tpr. Gura, BHQ K-9, advises he has the truck's shipping manifest. Load consists of $4864 \mathrm{kilograms}$ of Fissile class I, $20 \%$ solid uranium dioxide, N.O.S. UN2918 - Emergency Response Guidebook: Guide \#63.

0336 Springfield Fire calls SP Springfield re radioactive cargo at Route 91 accident. Advised of information on shipping manifest and discussion of precautions conducted.

0340 BHQ desk advised of Route 91 incident by SP Springfield. Request made for additional MBP officers at scene. Sgt. DJ Kennedy enroute from $B-5$ area.

0345 Sgt. Kennedy arrives at scene - assumes command of state Police operations.

0345 SP Springfield calls Vermont Yankee Nuclear Power station, consignee of nuclear fuel shipment. They advise Vermont Yankee representative will be enroute to scene \& will notify appropriate agencies (Nuclear Regulatory Commission, etc.)

0345 Springfield area Massachusetts DPW supervisor monitors incident on scanner and calls SP Springfield regarding MDPW assistance in traffic management. 
Commonwealth Ambulance Unit $\$ 60$ departs accident scene enroute to Springfield Hospital Emergency Room with one patient. Requests springfield and Mercy Hospitals be notified re possible radiological contamination.

0350 Captain Pereira, Acting District 1 Fire Chief, arrives on scene. Command Post set up in lobby of Marriott Hotel, Vernon street, springfield, just east of accident scene. Acting Chief Pereira contacts General Electric Company, wilmington, NC, and Vermont Yankee Nuclear Power station, Vernon, Vermont, for information on nuclear material involved in springfield incident. Chief Pereira is advised there is little chance of leakage from casks. Springfield Fire HAZMAT accesses unit computer for information on uranium dioxide - only information available is that material is radioactive and an evacuation area should be established. mergency Response Guide (1990), Guide \#63 seemed to conflict with information received from $G E$ and Vermont rankee. The Guide stated " External radiation hazard from unshielded radioactive material; Internal radiation hazard from inhalation, ingestion, or breaks in skin; Positive pressure self-contained breathing apparatus (SCBA) and structural firefighters' protective clothing will provide limited protection."

0355 SP springfield notifies SSGT Catellier, station Commander, of Route 91 nuclear incident.

0355 BHQ Desk notifies Captain Sheehan, Troop "B" Commander, of Route 91 nuclear incident.

0356 Commonwealth Ambulance Unit \#38 enroute to Springfield Hospital from scene with 2 patients Unit $\# 9$ dispatched to Command Post, Vernon street, on standby status.

0400 Sgt. Lapointe, MSP Commercial Vehicle Enforcement Unit arrives at Command Post. Observes truck and trailer fully engulfed in flames.

$0400 \quad$ Acting District Fire Chief Pereira upgrades incident to Level II situation - requests Fire Department Public Information officer at Command Post and that Springfield Fire Chief Cassanelli 
be notified. The upgrade to Level II status is not communicated to the springfield Police Department or other springfield response agencies.

0402 Acting Chief Pereira calls Timothy Bradbury of the Nuclear Regulatory Commission (NRC), who advises uranium dioxide is shipped in containers designed to withstand temperatures in excess of 3500 degrees fahrenheit and it was virtually impossible for containers to fail under fire exposure. Bradbury further advises that the fire can be fought in regular turnout gear with SCBA.

0403 Commonwealth Ambulance Unit \#38 arrives at Springfield Hospital Emergency Room.

0407 BHQ advises GHQ Communications section via TT of Nuclear incident, springfield, and that highway is closed from Exit 4 , northbound to Exit 7 , southbound.

0407 Acting District Fire Chief Pereira out to incident scene for size-up.

0410 Springfield Police Department closes the North End, Memorial, and South End bridges; city streets extending east from East Columbus Avenue to Main Street are also closed.

0415 Acting District chief Pereira makes the decision not to fight the truck fire due to the possibility of further damage to the casks from temperature stress, and diesel fuel and radioactive material washing down catch basins. Truck fire is almost burned out.

0425 SSGT Catellier, SP springfield Calls GHQ re Springfield incident. Colonel Henderson, ITC. Cronin, Majors Morse, Appleton, Roche and Cody notified; CVEU and Helicopter 1 activated. NIAT contacted.

0430 BHQ desk contacts Troop "B" 55 Team (6 officers) to report to springfield incident.

0430 Massachusetts DPW personnel begin arriving to assist with traffic control and the re-routing of Route 91 traffic to Route 5 . 
SP Springfield requests Chicopee PD close Route 391 re traffic control at incident scene. Route 291 closed as smoke from truck fire now affecting that highway.

0445

$\mathrm{BHQ}$ desk contacts $\mathrm{BH}, \mathrm{B}-1, \mathrm{~B}-2, \mathrm{~B}-4, \mathrm{~B}-5$ to contact one day shift officer and send immediately to springfield incident. Total of $11 \mathrm{MBP}$ day shift officers enroute to assist.

0450 James T. Controvich, Director of Springfield office of Emergency Preparedness arrives at the Command Post, Marriott Hotel.

0450

8pringfield Fire Chief cassanelli upgrades incident status to Ievel II situation, allowing springfield $P D$ to call in additional officers on time off for traffic control and other incident related duties.

0450 Media announcements made from Command Post that Routes $91,291,391$ and municipal parking lots under Route 91 were closed.

0510

Sgt. Higgins, SP springfield, calls BHQ requesting SP Helicopter for traffic monitoring. BHQ desk contacts GHQ \& is advised Helicopter 1 will be enroute shortly with Col. Henderson and LTC. cronin.

0530 Robert Leach and James Sinclair, Vermont Yankee Nuclear Power station arrive on scene and begin radiological monitoring at accident site.

0540

Captain Sheehan, Troop "B" Commander arrives at SP Springfield.

0545 Troop "C" Holden advise 5 Troopers and 1 NCO enroute to SP springfield to assist at incident scene.

0545 Massachusetts DPW personnel have detour signs and traffic cones in place - MSP officers at traffic control points. Traffic plan is to exit all southbound Route 91 traffic at Exit 13 (Route 5), all northbound Route 91 traffic at Exit 3 (South End Bridge to Route 5), al1 Route 291 west traffic at Exit 3 (Armory Street), and Route 391 south traffic at Exit 1 (Route 91 North). Springfield Police Department will man traffic control points at entrances and exits of Route 91 in springfield 
area. Columbus Avenue to remain closed. Municipal parking lots under Route 91 , affected by fuel spill and accident debris are to remain closed. Only the municipal parking lots at the springfield civic center and Morgan Square will be open for parking.

0600 Major Appleton, Bureau of Western Field Operations arrives at SP Springfield.

0600 Mr. Robert Leach of Vermont Yankee Nuclear Power Station advises monitoring indicates there is no radiation leakage from nuclear fuel casks. Truck fire is out - only smoldering debris remains:

0600 Robert $T$. Watson, Senior Radiation Scientist for the Massachusetts Department of Public Health arrives with NIAT Team (O'Connell \& Hill-Williamson) and begin radiological monitoring of accident scene and adjacent areas.

0600 Springfield Mayor Mary Hurley contacted and advised of incident status.

0605 Springfield Superintendent of schools contacted re incident and traffic situation - Determination made that Public Schools will remain open. No schools in incident area and no buses utilize Route 91.

0615 Sgt. Chaisson, MSP Commercial Vehicle Enforcement Unit, arrives at command post and is briefed by sgt. Lapointe. Both out to scene for size-up.

0630 Mr. Controvich, springfield Fire and springfield Police activate contingency evacuation plan. Springfield PD have held 50 school busses to be utilized if evacuation becomes necessary. If the isolation zone is 100 yards, only a small office building housing a public television station will require evacuation. If the zone extends to 2,000 feet, two to three thousand people will have to be evacuated.

0630 NIAT personnel on scene advise M8P 8gts. Chaisson and Lapointe that there is no leakage of radiation from the nuclear fuel shipping casks. Robert Leach, Vermont Yankee, advises that the casks should be allowed to cool before being moved to 
reduce the possibility of further damage. Two of the casks have sustained $1 / 2$ inch cracks along the sides, exposing the metal fuel rods.

0700 Sgt. Kennedy arranges for use of the West Springfield Fire Department Emergency Response Truck for use by MSP Personnel. There is only one house phone available in the Marriott Lobby, and the pay phones are being constantly used by the numerous media representatives who have responded to the Command Post. The West springfield Response truck has telephones allowing the state Police on-scene officers to communicate with SP Springfield and BHQ. Tpr. Ahearn, CVEU, is assigned to handle communications from that vehicle.

0725 Captain Bradley, MSP staff Inspections, arrives at the Command Post and is briefed by sgts. Kennedy and Lapointe. Incident operations are well under control; the incident traffic plan is functioning smoothly. State Police personnel are performing in an excellent, professional manner. sgt. Kennedy is coordinating MSP operations with both the Springfield Fire Department and Police Department. The Command Post atmosphere is chaotic, with emergency response personnel besieged by news media representatives. Communications from the command post also pose problems due to the fact that the repeaters being used by state police personnel have difficulty transmitting from the Hotel Lobby.

0730 MSP Helicopter 1 lands at SP springfield with col. Henderson and LTC. Cronin.

0740 There is discussion at the command post on whether to open the southbound lane of Route 91 , allowing southbound traffic to pass the incident scene, in order to reduce the traffic impact on the city of Springfield. It was the position of the state Police that the entire road remain closed for the following reasons:

1. Traffic, although of greatly increased volume, was moving steadily on Route 5 and adjacent roadways, with no congestion related blockages or incidents. 
2. The various news media accounts of the incident had created a public perception that the radiological risk at the scene was far greater than it actually was. This would have caused apprehension to motorists passing the scene in the southbound lane of Route 91 .

3. "Rubber-necking" by motorists passing the incident scene would create the potential for secondary accidents which would cause additional traffic management problems.

4. The southbound lane was being utilized as a staging area for response personnel.

5. The entire roadway would have to be closed in order to off-load the nuclear material from the burned trailer, and remove the vehicles involved in the accident. This would involve re-routing all southbound traffic a second time, creating confusion, and consuming incident resources.

0750 Col. Henderson, ITC. Cronin, and Captain Sheehan arrive at the command post in the lobby of the Marriott Hotel.

0800 Col. Henderson requests that a hotel conference room be obtained and set up with several telephones to alleviate present confusion and isolate incident personnel from the news media and other

distractions. After some initial resistance, a sixth floor conference room, with roof access to monitor the scene, is set up and an incident planning and strategy meeting is held. Agencies involved were:

\section{CITY OF BPRINGEIELD}

\section{Fire Department}

Chief Gary G. Cassanelli

Deputy Chief Mellis

Acting District Chief Pereira

Captain Donald Elliot, HAZMAT Training

\section{Police Department}

Chief Ernest Stelzer

Deputy Chief Daniel Spellacy 
sgt. Richard Whitehead

sgt. Donald sicard

Department of public works

Alex Chwalek, Traffic Engineer

Michael ottomaniello, Supervisor

Office of mergency Preparedness

James $T$. Controvich, Director

George Copeland, Radiological officer

Robert Shonak, Safety Director

Health Department

Randall White

Parking Authority

Al Andrews

Christopher Moskel

Mayor's office

Mayor Mary Hurley

Mayor-elect Robert Markel

Iaw Department

Harry Carroll

Bruce Leiter

Contract Ambulance Provider

(Commonwealth Ambulance)

Robert Turner

David clark

Personnel Department

Robert Shonak

\section{BTATE AGBHCIES}

Massachusetts state Police

Colonel Charles F. Henderson

It. Colonel Edward J. Cronin

Major Charles N. Appleton

Captain James M. Sheehan 
Captain Robert J. Bradley

Sergeant Daniel J. Kennedy

Sergeant Michael A. Lapointe

Nuclear Incident Advisory Team (NIAT)

Robert $T$. Watson

Thomas o'Connell

Laura Hill-Williamson

Massachusetts Department of Public Health

Robert Hallisey, Director, Radiation Control Program

Massachusetts Department of Public Works

Joseph Supraneau

Massachusetts Department of Environmental Protection

Robert Terenzi

Craig Golf

Massachusetts Emergency Management Agency

John Pappas, Regional Director

FEDERAL AGENCIES

Nuclear Regulatory Commission (NRC)

Paul Harris

Environmental Protection Agency (EPA)

Federal Emergency Management Agency (FEMA)

William creamer

Richard Quinlan

Department of Transportation (DOT)

James Hall 
Occupational safety and Baalth Administration (OBEA)

Robert Bak

Michael Goyda

Westover Air Force Base

Colonel Paul Hargis, Base Commander

Captain Robert Mooney, Base Security

George Copeland, Disaster officer

\section{PRIVATE BECTOR PARTICIPANTS}

Vermont Yankee Nuclear Power station

Robert Leach

James Sinclair

Michael J. Martin

General Electric Company

A. David Himle

Baystate Medical Center

Dr. John Santoro, Director of Emergency Services

\section{American Red Cross}

0900 Col. Henderson and LTC. Cronin out to SP Springfield then GHQ in Helicopter 1. Colonel requests frequent updates on incident status.

0900 After consultation with Robert Leach, Vermont Yankee, Robert Watson, NIAT, and Paul Harris, NRC, the isolation zone at the incident scene is reduced to 100 yards, allowing. the Memorial and North End bridges to be opened. Municipal parking areas south of the incident site are also being opened to the public.

0930 Extensive discussion takes place at the command Post as to who is responsible for the nuclear material involved in the incident. Vermont Yankee refuses to accept the material due to the 
possibility it is damaged. It is the general consensus that the General Electric Company is the present owner of the material and is the responsible party.

0930 NRC and NIAT officials approve the removal of the 1988 Toyota involved in the accident/incident and advise that the clean-up of the diesel fuel spill can commence. Environmental Products and Services of springfield, MA, contacted to clean up diesel fuel spill on Route 91 and the parking decks below.

0945 Environmental Products and Services arrive at scene and commence clean-up operations.

0950 Major Appleton, MSP Bureau of Western Field operations arrives at Command Post.

1000

Paul Harris, NRC representative, determines that the twelve casks containing the uranium dioxide fuel will have to be re-packaged before the material can be transported out of state due to cracks in two of the metal casks. Inspection and re-packaging is expected to take $24-48$ hours. A secure location in close proximity to the incident scene will be required. Various locations in the springfield area are mentioned and discussed.

1000 Concerns are raised about the overall traffic situation. Captain Bradley makes arrangements for City Traffic Engineer Alex Chwalek to utilize MSP Helicopter 2, which will also be used by Tpr. Hanafin to videotape incident activities.

1040 Traffic Engineer Chwalek advises traffic is generally flowing smoothly throughout springfield area. Minor adjustments made by springfield PD.

1046 General Electric Company, Worcester, MA, calls SP springfield advising they have a representative enroute to the scene.

1100 Meeting held with Mayor Hurley regarding a location for the nuclear fuel to be inspected and re-packaged. Three sites are possible: The National Guard Armory on Roosevelt Avenue, Springfield, The Western Massachusetts Electric Company yard on Caldwell street, Springfield, and Westover Air Force Base in Chicopee. The National Guard Armory site is discounted because it is situated adjacent to a hospital and an elderly 
housing project, both within the 100 yard isolation zone recommended for the material. NRC and NIAT officials preferred the WMECO yard, which is fenced, due to its proximity to the incident scene. Mayor Hurley and James Controvich recommended against the Caldwell street site, due to its proximity to a residential neighborhood 200 yards away, which would create a public perception of danger there. In addition, intelligence had been received by the mayor's office that nuclear protest groups were mobilizing because of the incident. There were also concerns as to whether sufficient security could be provided at the caldwell street location. Utilization of the Westover Air Force Base site had elicited strong opposition from Chicopee Mayor Richard Chessy, who did not want the nuclear material in his jurisdiction. The mestover site had a number of advantages: 1. it had isolated areas to store the material, 2. adequate security was already in place, 3 . base personnel had handled tactical nuclear weapons and materials in the past, and 4 . access to the base could be achieved with little exposure to populated areas.

1115 A. David Himle, General Electric Company, Worcester, MA, arrives and is briefed on incident status and discussions on a site for inspection and re-packaging. He advises it will take a GE team approximately 24 hours to prepare the material for transportation back to the GE nuclear fuel facility in Wilmington, North Carolina. A conference call is made by Mayor Hurley to Colonel Paul Hargis, Westover Air Force Base commander, and a request is made to store the nuclear material there during inspection and re-packaging operations. Colonel Hargis advises he will investigate the possibility, and a second conference call with westover is set up for 1300 hours.

1130 Captain Bradley calls col. Henderson and advises him of developments at the springfield incident. Col. Henderson advises that the secretary of Public Safety and the Governor are prepared to intercede in the site location issue if necessary in the interest of public safety.

1130 Team from Vermont Yankee Nuclear Power station arrives at the scene for transfer of nuclear fuel and cleanup. Trailer trucks from New England Electric Systems and Northeast Utilities will be used to transport the material from the scene. Mr. 
Gordon Faulkner, Vermont Yankee, will supervise removal operations.

1200 A formal press conference is held on the 7th floor of the Marriott Hotel. Major Appleton, Mayor Hurley, Fire Chief Cassanelli, Robert Leach, Paul Harris and Chief stelzer out to above.

1205 Captain Bradley requests SSGT. Catellier, SP Springfield station commander, at command Post re planning route of travel to westover Air Force Base if that site is approved.

1210 Vermont Yankee Nuclear Power station Team begins transfer of nuclear fuel casks from burned truck to new trailers.

1227 Diesel fuel spill clean-up sufficient to allow removal of 1988 Toyota involved in accident/

incident. Roy's Towing of Springfield contacted.

1235 MSP Helicopter 2 advises area traffic is slow but flowing steadily.

1245 Roy's Towing of Springfield removes 1988 Toyota from incident scene.

1300 Second conference call held with colonel Hargis, Westover Air Force Base commanding officer.

Westover agrees to accept the nuclear material. A discussion is held between command post personnel and Westover AFB on transportation routes, security issues, and facilities required for the inspection and re-packaging of the nuclear fuel. Westover can provide hanger space for that operation. Command Post personnel agree that the westover site should be utilized. Captain Mooney, Westover security, will be enroute to the command Post to discuss base entrance options. It is agreed, with some dissension, that no public disclosure will be made on the destination of the nuclear material.

1310 Mayor Hurley calls Chicopee Mayor Chessy to advise the decision has been made to transport the nuclear fuel to Westover Air Force Base.

1320 Tpr: Bennett, MSP Public Affairs, calls for incident update. Advised by Tpr. Gura.

1400 Colonel Henderson updated on incident status. 
Second Formal Press conference held on 7th floor of Marriott Hotel. Several representatives of national news media present.

1430

Captain Mooney, Westover Air Force Base security arrives at command Post.

1430 Vermont Yankee personnel have completed the loading of all twelve nuclear fuel casks onto three flatbed trailers. Trucks are staged in northbound lane pending escort.

1430 Harold's Garage, Northampton, MA, begins removal of tractor-trailer involved in incident. Harold's requested by Sgt. Lapointe, CVEU, due to that firm's past performance and expertise.

1448 Major Appleton out to incident scene to supervise escort of nuclear fuel to Westover Air Force Base in Chicopee. Route of travel will be Route 291 to Fuller Road, entering the Base through the Industrial Gate.

1500 Transportation of nuclear material begins from incident scene with state police escort (Major Appleton, Commercial Vehicle Enforcement Unit, and Sgt. Kennedy). Chicopee PD advised by SP springfield.

1500 Tires of trailer involved in the incident ignite as trailer is lifted from the smoldering debris. Fire extinguished by Springfield Fire Department. Harold's continues removal operations.

1530 Removal of tractor-trailer involved in incident is completed by Harold's Garage. Same removed from scene on flatbed trailers.

1530 Massachusetts DPW personnel at incident scene contact SP Springfield and advise they want to open Route 91 southbound and Route 291. SP Springfield advises officers at traffic control points to allow southbound traffic. The incident command post is not made aware of this action.

1530 Massachusetts DPW crews commence clean-up of fire debris at site of truck fire, and inspection of bridge structures for accident related damage.

1540 Route 91 southbound is now fully open to traffic. All southbound access ramps to Route 91 have been 
opened, and all city streets in the vicinity of the incident, with the exception of Liberty street, are being opened by the Springfield Police Department.

1540 Major Morse, GHQ Boston, advised that southbound lane of Route 91 is now open to traffic. Will advise Col. Henderson.

1545 Massachusetts DPW supervisor supraneau advises that guard rail repairs will have to be made before the northbound lane can be opened. Damaged guard rails at scene pose a threat to passing motorists.

1600 Nuclear material and escort has arrived at Westover Air Force Base without incident. Btate Police will provide one officer for security until the material is shipped.

1652 Massachusetts DPW clean-up and guard rail repairs are completed. Two lanes of Route 91 northbound are opened. The high speed lane is barricaded and will remain closed pending repair of pavement damaged by the truck fire.

1655 Command Post is closed.

1700 Major Morse, GHQ Boston, advised Route 91 northbound is now open to traffic and that command Post has been closed.

The involvement of the Massachusetts state police continued until the nuclear fuel left Massachusetts at approximately 1117 hours on December 18, 1991. Twenty-four hour security was provided at westover by state Police personnel. Troop "B" Headquarters also interceded when U.s. Department of Transportation officials decided to begin transport of the material on the evening of December 17 , 1991, during a snow storm that resulted in hazardous driving conditions on Route 91 in Massachusetts and connecticut. The chronology of these events follows.

\section{December 17,1991}

1230 Tpr. Brojan advises from Westover security detail that original plans made by DOT and Transportation Company to fly nuclear fuel out of Westover have been changed. At this time transportation by truck is being considered. 
Robert Hallisey, Massachusetts Department of Public Health, Radiation Control Program, calls BHQ re nuclear fuel from springfield incident. Material will be transported from Westover this date between 1900-2000 hours in two trucks accompanied by. NIAT personnel. Requests state police escort to the Massachusetts/Connecticut line on Route 91.

1800 Captain Mooney, Westover Air Force Base, calls regarding the transportation of the nuclear fuel from Westover. Move is now scheduled to take place between 2000-2400 hours this date.

2101

Captain Sheehan, Troop "B" Commanding officer is advised of plans to transport the nuclear fuel tonight. It is now snowing heavily, and numerous accidents are being reported on Route 91 . Captain Sheehan advises the Troop Duty officer to contact Captain Mooney at Westover to advise that the state Police strongly object to the material being transported in such adverse weather conditions due to the risks involved.

2110 Lt. McDonald, BHQ desk, calls Captain Mooney regarding state Police objection to the move under adverse weather conditions. Captain Mooney advises he also raised strong objections for similar reasons. The decision to move has been made by DOT personnel with the concurrence of NRC officials. captain Sheehan advised.

2125 Captain Mooney calls BHQ advising the decision to transport the nuclear fuel is now being reconsidered. Both trucks to be used in the transportation are one hour and twenty-five minutes late at present.

2208 Captain Mooney, Westover, calls re DOT has decided to reschedule transportation of nuclear fuel from the springfield incident until 0800 hours on December 18, 1991 due to the objections of the State Police and Westover officials.

\section{December 18, 1991}

0930 Department of Defense Police, Westover Air Force Base, call SP Springfield requesting state Police escort of nuclear material from springfield incident from the base to the Massachusetts/ Connecticut Iine. Tprs. Ashman and Lockhart, 
Troop "B" 55 team assigned, assisted by Tprs. Ye and Frigone, SP springfield.

1117

Nuclear fuel leaves Massachusetts enroute to General Electric Company, Wilmington, NC.

7.

\section{CRITIOOE BY PARTICIPATING AGENCIEB}

On January 13, 1992 a formal critique of the response to the December 16,1991 nuclear incident on Route 91 in Springfield, Massachusetts was held at the springfield Fire Training center. The critique was moderated by James $T$. Controvich, Director of the City of springfield office of Emergency Preparedness. Agencies and representatives were:

springfield Fire Department

Chief Gary G. Cassanelli

District Chief Walter Harmon

Acting Chief 1 Robert Pereira

Lt. David Larson

Lt. Anthony Amato

Lt. John Friberg

Dispatcher Richard Hanna

Bernard Welz, Public Information officer

9 Additional springfield FD members

springfield Fire commissioner

John Keough

springfield Police Department

Sgt. Donald Sicard

springfield Department of Public Works

Michael ottomaniello

James Poehler

Bpringfield office of Emergency Preparedness

James T. Controvich, Director

Robert Shonak, Safety Director

George B. Copeland, Radiological officer 
Commonwealth Ambulance

Robert Turner

David Clark

Yassachusetts state Police

Major Charles N. Appleton, Western Field

Captain James M. Sheehan, Troop "B" Commander

Captain Robert J. Bradley, Staff Insprctions

sgt. Robert $W$. Scofield, MEMA Liaison

sgt. Peter J. Higgins, SP Springfield

Sgt. Michael A. Lapointe, CVEU

Tpr. Jeffrey Ahearn, CVEU

Massachusetts Nuclear Incident Advisory Team (NIAT)

Thomas O'Connell

Laura Hill-Williamson

Massachusetts Department of Environmental

Protection (DEP)

Robert Terenzi

Massachusetts Emergency Management Agency (MEMA)

John T. Pappas, Regional Director

0.8. Nuclear Regulatory Commission (NRC)

William Lazarus

Joseph Furia

Federal Emergency Management Agency. (FEMA)

William Creamer

Richard Quinlan

J.8. Department of Transportation

James $\mathrm{Hall}$

0.8. Occupational Bafety and Health Administration (OBHA)

Robert Bak

Michael Goyda 
Vermont Yankeo Nuclear Power station

Robert Leach

Edward C. Porter

Baystate Medical center

S.M. Brahmauar, PhD

Dr. Paul A. Distefano, MD

Dr. John Santoro, MD

\section{Monsanto Chemical Company}

Phillip silensky (Observer status)

\section{Massachusetts Iegislature}

Representative Paul Caron, Chairman, House committee on Public safety

The critique began with discussion and comment on the initial response phase of the incident, with each agency being afforded the opportunity to address issues of concern.

\section{Massachusetts state Police}

Sgt. Peter J. Higgins, SP springfield desk officer during the incident, discussed communication difficulties experienced by the state police. From the initial notification of the incident, the phone lines at $\mathbf{s P}$ springfield were constantly tied up with incoming calls for information. At times it was impossible for the incident command Post to contact SP springfield or SP Springfield to make necessary out-going calls. This, and the lack of a common radio frequency, made it extremely difficult to maintain the necessary communications link with the springfield Fire and Police Departments. In addition, 8tate Police radio communications were hampered by the poor performance of the repeaters being used by officers at the incident scene. The group discussion that followed focused on the use of cellular telephone technology to resolve some of the communications problems experienced at major incidents such as this. This officer introduced the concept of a common statewide radio frequency for all Massachusetts emergency response agencies. This would require strong leadership and financial support from the upper echelons of state government. 
Mr. Controvich related that a question had been raised about the number of state police cruisers (6) involved in the escort of the nuclear material from the incident scene to Westover Air Force Base, in light of the Command Post decision to not make the material's destination public. Captain Sheehan explained that the decision had been made to utilize 2 cruisers per truck to be able to control intersections and other traffic related obstacles along the route of travel. In addition, there was a threat that nuclear protest groups might attempt to interfere with the transportation of the material.

Captain Sheehan also expressed concern that the state Police had no input into the decision to transport the nuclear fuel on December 17, 1991 during adverse weather conditions. There was no response to this issue by Federal authorities present.

\section{Commonwealth Ambulance}

Mr. Robert Turner, representative for Commonwealth Ambulance, the contract provider of ambulance service to the City of springfield, related that two of his firm's ambulance units had approached the scene from the northbound lane of Route 91. Both units learned that the truck was carrying possible radioactive material from state police personnel at the scene. Neither sp springfield nor springfield Fire Department had relayed information on the truck's cargo to ambulance dispatch. Upon arrival, one ambulance was directed by state Police personnel to drive through smoke from the truck fire to reach a patient. The ambulance driver, unsure of the nature of the threat, reversed direction, and approached the scene from the opposite direction, avoiding the smoke from the truck.

\section{Springfield Fire Department}

Richard Hanna, Springfield Fire Department dispatcher, related the sequence of events during the Fire Department's initial response. Acting District Chief 1 Robert Pereira explained his actions as the ranking Fire Department representative in the initial stages of incident operations. Information from vermont Yankee and the General Electric company as to the radiological hazard seemed to conflict with the Emergency Response Guide, Guide \#63, and little information was available from the springfield Fire Department's HAZMAT computer data base. In adition, there was a question as to whether the radiological monitoring devices being utilized by fire department responders (1950's civil defense issue) were accurate and providing true readings. There was then a lengthy discussion on whether 
radiological monitoring equipment utilized by emergency response personnel was being periodically maintained and calibrated. Some agencies responded that their instruments were maintained at the prescribed intervals, others had instruments that had not been checked for years. Modern, technologically advanced equipment would provide greater assurance to emergency responders.

Acting Chief Pereira also stated that the extensive diesel fuel spill at the scene affected his decision not to fight the fire for environmental considerations. By the time sufficient information had been obtained on the nuclear material and it's hazards, the fire was almost out, and the threat of thermal shock from cold water causing additional damage to the metal fuel casks was a factor.

William Lazarus of the Nuclear Regulatory

Commission explained to the group that the nuclear casks used to transport uranium dioxide are designed to withstand any type of transportation accident, including fires involving high temperature. It should be noted, however, that two of the metal casks were severely twisted, with $1 / 2$ inch cracks extending along the sides.

\section{springfield Police Department}

Sgt. Donald sicard of the springfield police Department advised that his department had been notified of the truck's nuclear cargo by state Police springfield, and had been requested to provide assistance in closing entrances and exits to Route 91 . Because the Fire Department had declared only a Level I situation initially, the police department was unable to call in additional personnel, and the demand for their services quickly outstripped available manpower. Sgt. Sicard stated that an incident being handled as a Level I situation for the fire department, may, due to manpower commitments, be a Level II situation for the Police Department. Under the city of Springfield Emergency Response Plan, a Level II situation is required before additional personnel can be called to duty on overtime status. Mr. Controvich agreed to investigate this issue further.

In addition, when Acting Chief 1 Pereira upgraded the incident to Level II status at 0400 hours, this information was not communicated to the Police Department, which continued to operate under severe manpower shortages.

sgt. sicard brought up another police department concern. Because the nuclear fuel did not require placards under Federal regulations, it would be difficult for incident responders to know what the truck was carrying if the driver 
had been severely injured, or unconscious. The same concern had been considered by this officer during initial analysis of this incident. I had previously spoken with sgt. Lapointe of the commercial vehicle Enforcement unit on the possibility of presenting a short block of instruction on the recognition of nuclear packaging, which is uniform and standard under Federal regulations. A short familiarization segment during in-service training would assist state Police personnel in recognizing materials at transportation accidents. Colored slides depicting the various packaging are readily available from the U.S. Department of

Transportation. Springfield PD will consider such training.

\section{Bpringfield DPW}

Michael ottomaniello, Springfield Department of Public Works supervisor, stated that due to the fact that no catch basins or manholes were affected, his department was able to concentrate its resources at providing barricades and other assistance to the springfield PD at traffic control points. Mr. Ottamaniello's perception was that incident operations went very well.

\section{Massachusetts DPW}

Massachusetts Department of Public Works representatives had not been made aware of the critique, and were not in attendance. It was noted, however, that their response was excellent in the re-routing of traffic off Route 91 onto Route 5. Scene clean-up, guardrail repair, and bridge inspection were also conducted in a similar manner.

\section{Baystate Medical Center}

Doctors Distefano and Santoro discussed the problems encountered by physicians called into duty at the hospital when a radiological emergency was declared. Doctors attempting to reach the hospitals encountered traffic control points, and were turned away. With limited or no information on the traffic situation, many experienced great delay in their arrival at the hospital, which would have impacted on medical care in a multiple casualty situation. This situation can be rectified by improved communications. Upon notification by hospital and EMS, traffic control points can be notified to assist medical response personnel in reaching their assigned facilities.

Also discussed was the lack of a communications link between Medical services and incident operations. Hospital personnel had no knowledge of incident activities or the potential hazards involved. The hospital had received a 
call that a black cloud was approaching springfield Hospital, which caused apprehension and concern on the part of medical personnel. At 0545 , one doctor reporting for duty reported that a local radio station was talking about the evacuation of the city. Improved communication with medical facilities will be discussed at future meeting of the Local Emergency planning committee.

The critique then focused on Command Post issues. There was extensive discussion by emergency response representatives on the reporting of the incident by the news media. Media accounts created public perception of danger that was far out of proportion to the actual risk involved. Local television coverage on the evening of the incident used such descriptions as "Nuclear winter averted in springfield", and others that reinforced the public's perception of danger.

This officer suggested that in future incidents the Incident command system concept be utilized to deal with the media. This requires that all information on incident activities be released only by the Incident commander or the Information officer assigned to handle that function. In this manner only accurate information approved by the Incident commander is released, eliminating conflicting accounts.

A second related issue, which provided a major problem in the management of the incident, was the establishment of the command post in the lobby of the Marriott Hotel. Initially the lobby was acceptable, but as the incident escalated, and the press began arriving, contact with the media began to have a detrimental effect on management operations. The movement of the command post to a sixth floor conference room, allowing control of media representatives, mediated this problem.

Sgt. Sicard, Springfield Police Department, discussed communications problems at the sixth floor command post. Although three telephones had been provided, phone access was periodically difficult. Sgt. Sicard felt that Federal and state agency representatives were tying up the phone lines with lengthy conversations. It should be noted that except for brief calls to SP springfield to respond to incident requests, the majority of out-going state police calls were made at public phones, using credit cards.

Mr. Controvich also addressed communication problems with the General Electric Company. A call had been made to General Electric to ascertain who was going to be the clean-up contractor for the incident scene. Mr. Controvich stated he was advised GE would discuss the issue and call the 
Command Post with the information. There was no further contact from the company. Environmental Products and Services was then utilized.

There were no other problem areas that surfaced during the critigue. The consensus was that overall, there was a very good integrated response to the incident.

8. I88UES OF CONCERN AND RECOYNENDATIONB FOR ROTURE IMPROVEXENT

Issues of concern affecting the performance of the Massachusetts state Police are listed below, along with any recommendations for improvement:

\section{Communications Equipment}

This multi-agency response emphasizes the need to reevaluate state Police communications capabilities for major incidents. Currently telephone systems at state Police installations are designed to transfer calls to the next available line. The experience with this incident indicates that this system fails under a heavy volume of incoming telephone calls. This officer recommends that at least one separate non-published telephone line be installed in all state Police sub-stations. This separate line, in conjunction with the station's centrex line, will solve the telephone related communications problems encountered in this incident.

The inability of on-scene state Police personnel to maintain a communications link with other incident response agencies, and to make secure communications within the incident area and to state Police installations, is another area that has to be addressed. Providing mobile cellular phones to supervisors, with a number of portable units at each sub-station and Troop Headquarters would greatly improve communications capability in this area.

The performance of the Btate police radio aystem and repeaters continues to present problems. The only solution is an upgrade of the entire system, which is under consideration.

\section{Communication as a Process}

There were several instances of the failure to communicate necessary information during the course of this incident. Those involving the state police were the failure to notify Commonwealth Ambulance of the radiological hazard 
immediately upon recognition, and the re-opening of the southbound lane of Route 91 without communicating with the Command Post. As the Incident command system becomes assimilated into state Police operations, communication as a process should improve.

\section{Personnel Performance}

This incident, especially in the initial stages, placed numerous demands and responsibilities on state police personnel both on-scene, and at sub-station and Troop levels. Perimeter control was quickly established, notifications were made, traffic plans were developed, and coordination with other response agencies was ongoing. Personnel performance was excellent through the entire operation.

\section{Equipment}

There is a definitive need for mobile command posts for hazardous material transportation accidents and other major incidents. These units should have state of the art communications capability, as well as CAMEO (Computer Aided Management of Emergency operations) access.

This incident also illustrates the need for calibrated, functioning, radiological monitoring equipment to be available to field personnel.

The state Police Commercial Vehicle Enforcement Unit (CVEU) is an integral part of the Department's response to hazardous materials transportation accidents. The unit's response was excellent to this incident; Sgt. Lapointe was on-scene within 42 minutes from the accident's occurrence, providing guidance to state Police personnel. The unit's personal protection equipment is damaged and obsolete, and it's HAZMAT reference material is outdated. This incident is an example of the importance of up to date reference material; if sufficient information was available to the fire Department on a more timely basis, the truck fire could have been extinguished, instead of being allowed to burn out. This would have resulted in the incident scene being cleared 3-4 hours sooner. Rapid clearance is a prime objective of the state Police traffic incident management effort.

\section{Training}

The rapid recognition of hazardous materials by state Police personnel responding to transportation accidents is an important responsibility that greatly impacts on incident outcome. In this incident, the truck driver was able to advise state Police personnel of the nature of the 
cargo, which did not require placards under Federal regulations. Had the driver been severely injured, this information might not have been available in a timely fashion, as the labels on the nuclear fuel casks could be easily overlooked in the confusion of the accident.

The packaging of radioactive material is controlled by Federal regulation. It is standard throughout the industry based on the nature of the material being transported. It is recommended that the state police conduct a short training segment on the recognition of nuclear material packaging. Colored slides on the different types of nuclear packaging are available from the U.S. Department of Transportation. I have spoken with Lt. Trepasso, Academy Commandant. A short program (30 minutes) could easily be incorporated into the next in-service training period.

\section{Vehicle Removal}

The rapid clearance of incident scenes is a major objective of the Department's traffic incident management efforts. Once the hazardous materials situation has been mitigated, vehicles can be removed, and lane capacity restored. In this incident, the wrecker service utilized to remove the completely destroyed tractor-trailer was selected on the basis of it's expertise and past performance. It should be the policy of the Department that the Incident Commander determine the wrecker service to be used, present policy notwithstanding, to ensure the expeditious resumption of vehicular traffic at the scene.

\section{Incident costs}

Department costs in a major incident can be substantial. During the state police response to the springfield incident, 141 hours of overtime was expended for Troop "B" and Troop "C" personnel, this does not include overtime for staff and CVEU officers present at the scene. Equipment costs for cruisers and state Police Helicopters were significant. Massachusetts General Law Chapter $21 \mathrm{E}$ (Massachusetts $0 i l$ and Hazardous Material Release Prevention and Response Act) provides for the reimbursement of reasonable costs to emergency response agencies by the party or parties liable for the hazardous material incident.

Section 4 states: "Any person who undertakes assessment, containment or removal action regarding the release or threat of release of oil or hazardous material shall be entitled to reimbursement from any other person 
liable for such release or threat of release for the reasonable costs of such assessment, containment and removal."

"Person" is defined in Section 2 of Chapter $21 \mathrm{E}$ as: "any agency or political subdivision of the federal government or the commonwealth, any state, public or private corporation or authority, individual, trust, firm, joint stock company, partnership, association or other entity, and any officer, employee, or agent of such person, and any group of persons."

The city of springfield is currently seeking reimbursement of over $\$ 16,000$ in incident related costs: Successful recovery has been made in the past for straight time, overtime, and equipment costs under the statute's provision for the reimbursement of "reasonable costs".

It is recommended that the Massachusetts state Police adopt the policy of seeking reimbursement for hazardous material incident expenses under the provisions of Massachusetts General Law Chapter 218 .

\section{Involvement in community planning}

The Springfield nuclear incident illustrates the need for the Massachusetts state police to become involved in the community planning process. Transportation accidents and other incidents on the major highways of the commonwealth directly affect adjacent communities, which must activate their emergency response plans and commit resources to mitigate that impact. As a result of the springfield incident, the Troop "B" commander will participate in future Local Emergency Planning Committee (LEPC) meetings. Active participation creates an understanding of the roles and responsibilities of the varied emergency response agencies, and results in greatly improved planning and response.

It is recommended that rroop commanders become actively involved in Local Emergency planning committee activities.

9. The January 13, 1992 critique of the springfield nuclear material incident provided an accurate representation of the problem areas encountered. Although there were communications problems (both equipment and agency related), the integrated response to this incident was very good. 
A contributing factor to this success is the excellent LEPC activities of the City of Springfield. As a result of a leaking propane truck incident in December 1987, and a major chlorine fire in June of 1988, Springfield has learned the value of emergency response planning. Elements of the Incident command system are utilized in the formulation of these plans.

In addition, the springfield Fire Department is considering the adoption of the National Fire Academy Incident command system. This would allow the Massachusetts state Police and the city of springfield to operate under the Incident command system during major incidents, further improving incident performance.

Respectfully submitted,

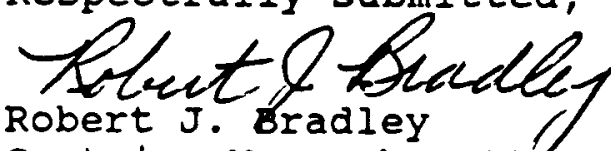

Captain, Massachusett's state police Staff Inspections Unit 


\section{APPENDIX D}

Springfield Fire Department Reports and Correspondence 
S.F.D. Fearquarters

6ns worthingtan St.

Sofle, Mass.

December 19,1991

Gery Cassanel11. Chief

Sprid. Fire Dept.

Degr Chter.

The following is a report of incldent $\$ 01730 \%$. Dec. 16, 1991 inrolrting rehicle acclient and fire on I-a1 Northbound.

At. $n 318$ hrs. on Dec. 16, 1991, E-7 was disoatched for an accleent. ant fire on I-al vorthhound fust north of gavstate iest. A fow mquites later I recequet a tolechnne call from tisogtich informlng me that, a truck involvet in the accijent, mav hare been carrvine nijelear puel. T instructed the tisoatcher to chsogtch the HazMat Team alone with myselr.

At 0321 , E-7 radioed ilspatch that, they were golns to stage at East Columbus Ave., and Boland Way unt.l they recelved more Imformation from State Pollce who were glready on scene anr. in Dosession of the shloplag dapers. Lt. Iarson, E-7, then announcet nver the radin a Level 1 HazMat sitilation.

As I arriper at East Columblis Ave: and Boland Wav, we recefred a report, that the trick was carrvino 450 n arams of Urantism Dioxite. I then instructed Lt. Larson to use the HazMat, reperence librarv to research Urantum Dinxide. T then instrifcter Hlsoatch ton have State Pnllce ant Sofld. Police to c?ose town both the North hound and South bound lanes of $T-91$. West and East. Columhus Ave, ant any access routes to I-91. 
I then requester the state Police to set the shlootng oaders to me as soon as oossihle. A Command post was set un in the lohhy ne the Narriott, Sotel. The truck adoeared to be ruliv involvet in pige from this rantage botht. At this onint. I had decited to let, the fire burn and keep evervone, including flre dept. dersonnel away from the truck. I then took an elerator to the sixth floorof the Marrlot, Hotel to get a better look at the Incldent. From the sixth floor. with binoculars. I could see the truck nearIvfully involved with fire. There appeared to be 8 or 9 long rectanaular shaped crates on the flatbed portion of the truck. Two of these contalners were layine on the oround to the left of the rlather. (looking from the rear of the truck). Flolng me the Imoression that they were jarred loose in the accirent. The rather was uorlaht. on 1t's wheels, but the cab of the truck gooegred to he on 1 t.'s stie, al hough tt, was hat to he sire. hecaluse 1 t was bretty well demollshed with darts strown all over the hlahway as well as helow the hlohway. About i so reet snith of the truck, a small sports car was uo agolnst, the guartratl. The car had recelved extensive damage to the passenger side. When the shlpping papers arrived I reallzed that the truck was carryina 4500 Kllokram of Uranlum Dioxide (aoprox. 10.000Ibs) not 4500 grams. I placed. call to the shipper. General Electrlc ro.. Wilmington, N.C. I was informet that. the IIrantium Dioxide is shlooet as dellets, nackgred in steel rots, whlch are in turn encaser in tnuble walled steel containers destonet to withetand an inererno. I then nlaced a teleohane call to Vermont Yankes vuclear Plant. Vernon Vernont, the testingtinn ne the shlpment. I spoke th Robert Leach. a plant offlcial. who sove me the same Information that General Electrle had flven me. Mr Leach inrorned 
me that he would Immediately respond with a clean-up tegm ant radloactive testing equipment. I then save dispatch an update via radio and requested that Chler Gary Cassanel11 and D.E.P. be notified. I then requested for Bernle Welz. Fire Dept. Spokesman. to be called in and uperaded the inclient to a Level 2 . I then spoke on the phone to Tlm Bradbury of the Nuclear Bezulatory Commission. He informed me that Uranium Dioxide was shipoed in contalners testaner to withstand temberatures in excess of $350 n$ iegrees $F$ : and that. It was virtually lmoossible for the conteiners to pall unter fire exposure. He told me we could aboroach the rire and extinelish 1 t. usino regilar turnout gear and self contalnet breathing adogratus and that he would send a renresentetive. I then took a ride up onto I-ol to get a closer look. I Alscovered that diesel fuel had sollied over a wide area. (about $10 n \times 150$ feet). I decided not to extingulsh the flre because at this point the fire had nearly burned out and puttine water on 1 roult onlycomplicate clean-ub operations as water wold wash tiesel ridel into the storn drains and the area beneath I-91. Shortly arter thls Chief Cassanelli. Bernie welz, Chler Melis and Cadt. Ellint, arrivet. Bobert, Leach from Vermont. Yankee then arrqued and heoan conducting tiest. fnI the onssintlity ne ratiation. The S.F.D. Rescue squad assistipt Mr. Leach. At approximately ofno hrs. I was relleved by District Chief W9111am Verovellt.

Respectively Submitted;

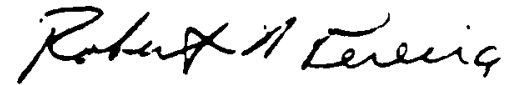

Actina District Chief I Robert. Perelra 
- who sere contacted andifur responded:

- 'Spifid Fire Dept

- $S_{p} f l \hat{\alpha}$. Police Dept.

- State police

- DEP.

- DE .P.

- Robert Leach-V'ermont Yankee Nuclear Plant

- Paul Harris - Nuclear Regulatory Commission

- Jim Cintrovitch

- Commonwealth Ambulance Service - transported injured victims before our arrival

- Baystate Medical Center - to attempt to get information from truck driver and to warn hospitals of possible radioactive contamination of victims

Injuries:

Joseph Dunn Age 58 unknown injuries (truck driver)

$$
\begin{aligned}
& \text { Janet Dunn Age } 43 \\
& \text { (passenger in truck) }
\end{aligned}
$$

John Byre Age 27 " (autorncbile operator)

Reviectivily submitted Reit A Punic Robert Pareira

D -4 
Headcuarters Fire Station Ladoer Company" \#1, Group $B$ 605 Worthington straet

Spfld., MA 01105

Chief Gary Cassanelii

Springfield Fire Department

605 Horthington street

Springfield. MA 01105

Dear Chief Cassmenli:

As you requested, the following is a report of the actions taken by Ladder Conpany \#1, Group B, on Monday, December 16, 1991, at the Haz Mat fire on I-91. Ladder Company \#1 and the Hazarcous Material truck responded to Boland Way in front of the Marriott Hotel by way of a vocal alarn at 0322, along with Acting Chief Robert Pereira.

We met Lieutenant Larson in front of the Marriott and he informed us of the situation. There was a car - truck accident; the truck, involved with fire, was carrying radioactive materials. The state Police Sergeant then gave us the manifest from the truck, informing us that the shipment contained uranium dioxide. We then set uf the generator for. the computer for research purposes.

After Acting Chief Pereira's decision to let the vehicle burn, there was not much work to do. The Hotel Manager let us view the accicent scene from the 8th Floor, Room 832. The State Police had closed the highway and were clearing the area. There were no other vehicles in the immediate area of the accident.

We did assist the different local and state agencies by providing whatever information that was available to us. We were relieved by Group $D$ around 0700 and returned to quarters.

Receivec... $12 \cdot 2 \%$ - 121

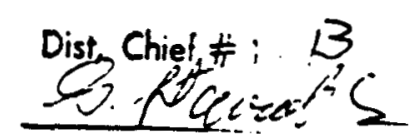

Respectfuliy submitted.
Eicutatant Comato
Lieutenant anthony Amato 


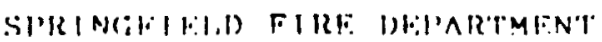

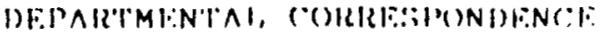

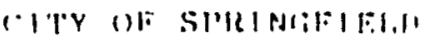
MASSACIIUSFT'S

TO: Chief of Department

1)คTE: $: 2-28-91$

FROM: LE. David Larson

\section{DIVISION/COMINAY:}

DIVISION/COMMINANY: Eng ine 7

COPJES TU:

SUB.JFI:T: Incident \$ 917308

On December 16. 1992, at 0322 Engine 7 responded to a truck fire on $I-91 N$ near Boland Way and $E$. Columbus Ave. While en-route, E-7 was notified by dispatch that the truck was carrying radioactive material. I instructed the driver to proceed to Boland Hay in order to oive me view of the situation from a distance. Upon arrival. I saw a vehicle involved in a fire.

Through a few communications with dispatch, I tried to determine from the police what the situation, on the highway was. During this time, dispatch had called for the rest of the haz. Mat. team and Chief 1. Also, E-7 members noticed one ambulance leaving the scene and another en-route to the accident.

Shortly thereatter, Chief 1 , Ladder 1 and squad arrived on scene and I informed them of the situation up till then.

Dispatch then communicated to me the name of the material loaded on the truck. E-7 started research on the material and shortly thereafter the state police arrived on Boland $w a y$ and handed me the shipping manifest.

I spoke to the state trooper about evacuating and isolating the the area around the incident. He informed me that this was being done while we spoke. We also discused shutting down portions of I- 91 north and southbound.

The Haz-Mat team was able to determine little about the characteristics of the material other than it was radioactive and an evacuation area should be established. About this time, I used a geiger counter to take readings in the vicinity of the Marriot Hotel on E.Columbus Ave. There were no detectable readings on the counter in this area.

since re-routed traftic from the highway was travelling on $E$. Columbus Ave. northbound, and close to the accident, I asked Springfield Police to block traffic going in that direction. After receiving a report that smoke from the incident was travelling down I-291, I asked the state police to shut down that section of the highway,

E-7 stood by until about 1030 hrs. and gave assistance and provided information to local and state authorities during the remainder of our time on scene.

Received \& forworded $12-29-2 /$

Dist, Chief \#1- 13

FORM SFD $\overline{17}$
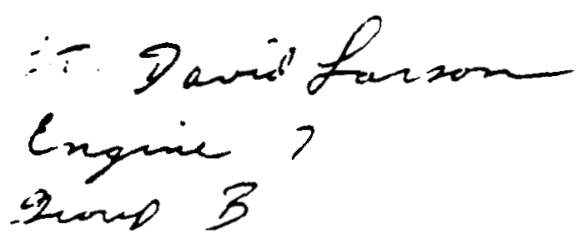
SPRINGIPI HID FIRF DHIARTMFNT

DEPARTMINATAI, CORRISIPONDENCH

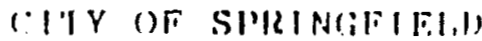

MASSACHUSlip'l's

TO: Chief Gary G, Cassanelli

DIVISION/COMINAN :

COPIES TO:
DNTE: December 29, 1991

FROM: John F. Friberg

Lt. Rescue Squad

DIVISION/COMPANY: GrOUD B

SUBJE.CT: Inc."1917308

District Chief I

District Chief Mellis

Dear Sir,

On December 16, 1991 at 0318 the Rescue Squad received a vocal alarm to assist E-7 with a truck fire involving possible radlo active materials on Interstate 91 north opposite the Marriott Hotel. Thile enroute to this incldent I was iistening to $E-7$ officer giving the Alarm. Operator an update on what he was told had happened on the Interstate. I then radioed Alarm and told them that he should have Chief I respond also, he told me he was in the process of doing that at this time. The squad route to the scene was State St. to E. Columbus to Boland Way. When I arrived on scene I talked with Lt. D. Larson on what info he had as to the incident. All the info that he had was that a truck containing radio active materials was on fire. We then drove the Squad to Main St. and Worthington St. which was about opposite of the truck. I looked from my binoculars and could see the front portion of the truck engulfed in flames and a small fire under the main roadway on what appeared to be a shed roof. Upon returning to Boland Way and $E$. Columbus Chlef I, Capt. R. Pereira had just arrived on scene. I told him what I had seen from my binoculars and Lt. Larson was briefing him on what he knew. While talking to Capt. Pereira, two ambulances were going North on 91 to the scene and shortly thereafter were coming back going South in the North lane, we contacted the ambulance $C o$. to see what they knew about the incident and to see if people were involved or trapped in the autos. Their dispatcher told Chief I that no ambulances had been sent to that location on Route 91. Meanwhlle the Stace Police that were located on Route 91 had a lot of the traffic from State St. ramp moved back. So Chief I, Myself, and Chlef I Aide drove up the State St. ramp to Route 91 North to talk to the state Trooper. He informed us that a car driving South in the North bound lane hit a tractor traller golng North, the injured parties had already been removed from the scene at this time. Chief I and myself thought it was much safer to let it burn until we could find out information about the contents of the truck. Looking at the tractor and trailer from our location 1 t looked like the rear section of the trallers load was still intact and not on fire, the front section

cont. 
was involved in fire and it appeared that two of the large cases had fallen off the trailer and were between the trailer and the center strip guard rail. We then returned to the Marriott Lobby where a State Trooper had brought the Shipp lng papers that he took from the tractors cab when he had arrived on scene. Lt. Larson was the HazMat team leader on this tour of duty so he had the research team start looking up Information from our resources and used the Hotel phone to call the shipper which was General Electric. When General Electric had no immediate answer I suggested to Chief I t hat we call Yankee Nuclear Power Plant where 1 t was being shipped as they deal with it daily, maybe they could help us out. When General Electric called back, Chief I informed me that there was no way the cylinders could leak. Meanwhile a return call from Vermont Nyclear plant stated, do not put out the fire and stay clear, they would send people down and be there within an hour. At this time Acting District Chief Pereira decided that we would let it burn until it burned itself out. Rather than put it out and maybe do more damage when the cold water hits hot metal, and by doing it this way we wouldn't have to expose anyone. We then stood by, periodically checking from the eighth floor of the hotel with binoculars the condition of the scene, until other more experienced personnel arrived. I wastelieved on scene at 0730 by Capt. Richard Pareira. Other members of the Rescue Squad were W.Posley, I. Menuade, and J. Barker.

Respectfully Submitted,

cheat got un te Erelong

John F. Friberg

Lt. Rescue Squad Group B

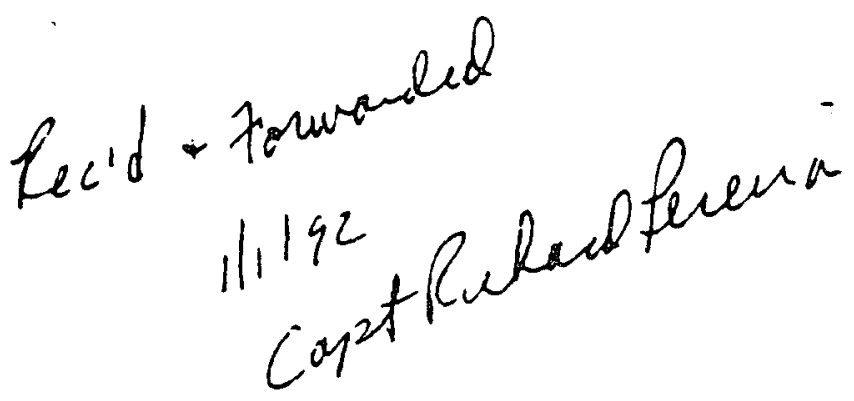

D-8 
GPS- 17

DEPARTMENTAL AND INTERDEPARTMENTAL CORRESPONDENCE CITY OF SPRINGFIELD MASSACHUSETTS

DATE: $2 / 27 / 92$

To: Jim Controvitch

From: Capt Robert Pereirs

DEPARTMENT:

COPIES TO:
DEPARTMENT: Fire

SUBJECT: Nuclear Incident on $7-91 / 91$

$\operatorname{Sim}$

I could nit find my copy of the letter I submitted to Chief Cassanelli on the events of the Nuclear Fuel Incident on I-91, Dec 15, 1991.

I have listed for you below the agencies I contacted for advise and the advise they gave me:

- Robert Leech, Vermont Yankee Atomic Plant Advised me to isolate area, keep people away, do not attempt to approach vehicle and that he world be on scene within an hour with his own team.

- General Electric Co, wilmintom N.C., shipper Advised me not to attempt approaching vehicle, let burn, keep everyone away.

- Bob watkins, Nuclear Incident Advisory Team same advice as from above

D-9 
GDS- 17

DEPARTMENTAL AND INTERDEPARTMENTAL CORRESPONDENCE CITY OF SPRINGFIELD MASSACHUSETTS

DATE:

TO:

DEPARTMENT:

COPIES TO:

FROM:

DEPARTMENT:

SUBJECT:

- Nuclear Regulatory Commission

Originally spoke with Tim Bradbury who advised us not to approach vehicle and to wart for Mr. Leech from Vermont Yankee to cirrive. Later, I received a return call from the NRC informing me that the product being carried was a very law level radioactive and that we could approach vehicle and extinguish the fire without any danger.

At this point the fire was nearly burred ont except for the tires To put out the fire in the already damaged tires would have required a lot of water which would have compounded the problem of the fuel spilled on the highway. We dick not have enough dry chemical extinguishers to put out the fire so I made the decision to let the tires burn.

I will have Ch. Cassanelli forward you a copy of my letter to him as soon as le returns.

D -10 


\section{APPENDIX E \\ Emergency Medical Service Reports}

Commonwealth Ambulance Service, Inc. 


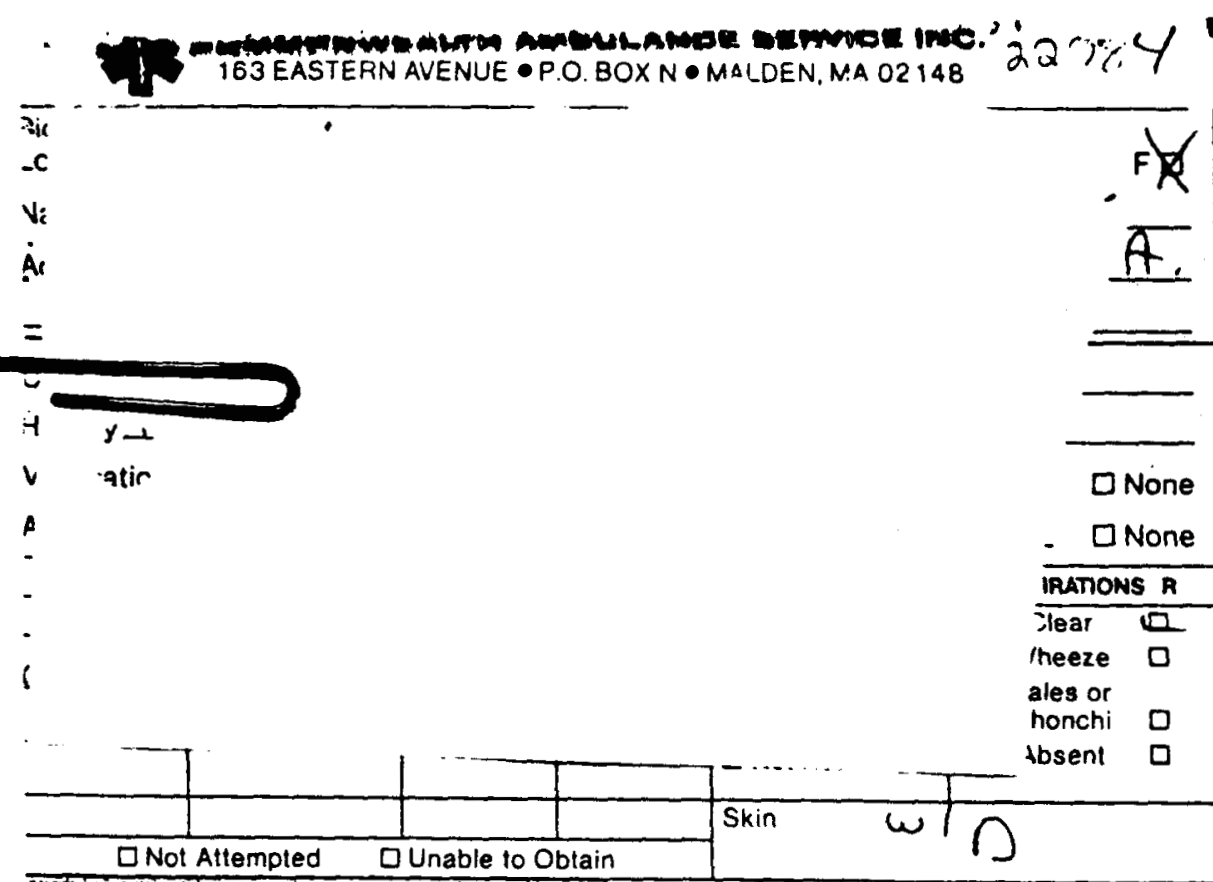

EMEROENCY MEDICAL SERVICES REPC No. 918089

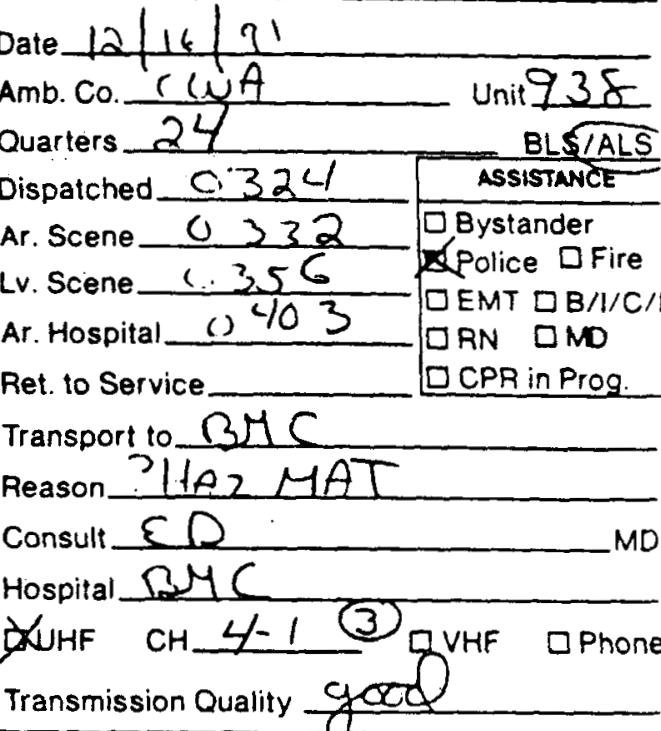

Transmission Quality
BLS - EQUIPMENT/PROCEDURES

\begin{tabular}{|c|c|c|c|c|}
\hline $\begin{array}{l}\text { Eyateris } \\
\text { Openjog ti }\end{array}$ & $\begin{array}{l}43 \text { pópitaneo } \\
3 \text { To volce }\end{array}$ & $\begin{array}{l}2 \text { To Pain } \\
1 \text { None } \\
\end{array}$ & $\begin{array}{ll}\text { Respiration } & 10-24 \\
\text { Rate } & 324-35\end{array}$ & $\begin{array}{ll}1 & 1-9 \\
0 & \text { None }\end{array}$ \\
\hline Verbal & 50 & & 236 & \\
\hline Response & 4 Conlused & 1 None & Expansion (1) Normal & O Retractive \\
\hline & 3 Inapprop. & & Systolic BP (4) 90 & 10.49 \\
\hline $\begin{array}{l}\text { Motont } \\
\text { Bopons }\end{array}$ & $\begin{array}{l}\text { Gobedience } \\
\text { spupposefut }\end{array}$ & $\begin{array}{l}3 \text { Flexion } \\
2 \text { Extension }\end{array}$ & $\begin{array}{r}370-89 \\
250-69\end{array}$ & O No Pulse \\
\hline 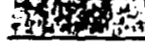 & Withot & & Caplliary (2) Normal & O None \\
\hline Coma Scal & $(3-15)$ & & Refill 1 Delayed & \\
\hline 8 & 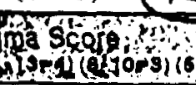 & $\therefore \therefore$ & Tolal Trauma Score & \\
\hline
\end{tabular}

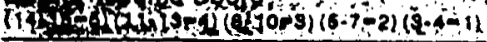

Condition Pt. Found

aimb. (O) oseme

jeced tum is T.T. civensfid in Silimes

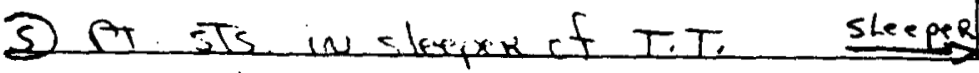

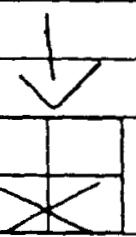

口02 $\mathrm{L} / \mathrm{m} \quad \mathrm{CPR}$

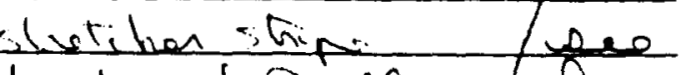

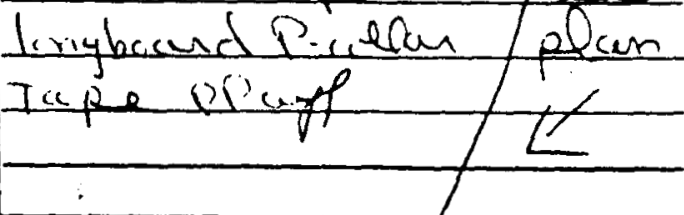

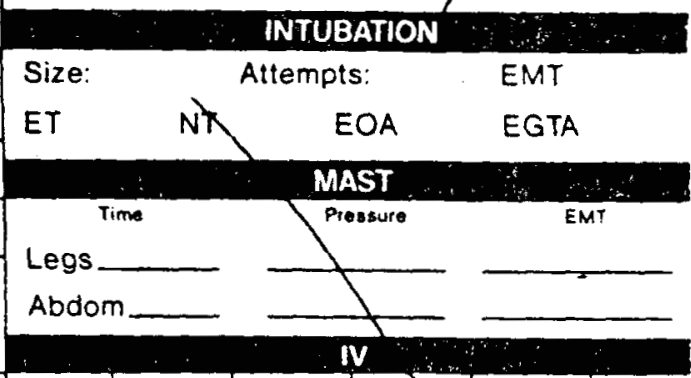

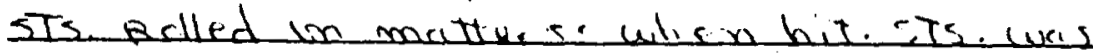

buweed akcund on. id $f$, is AL.O.C., ReHaved self, ambists was away from T.T. who in tive stawted sts

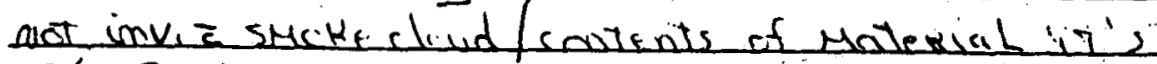
c/c (1) flank (B) LAT. calt prin

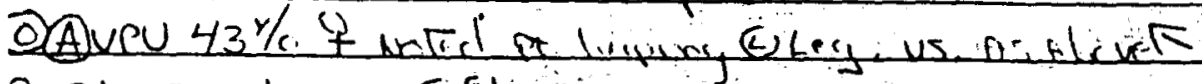

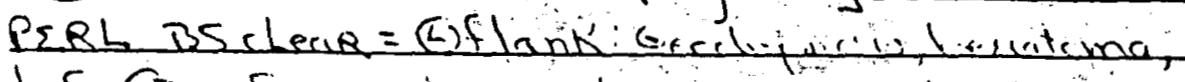

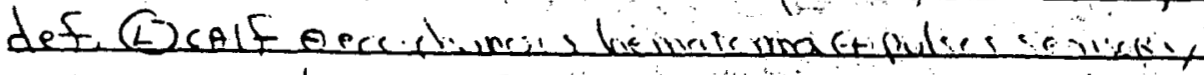

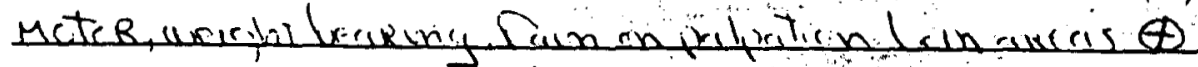

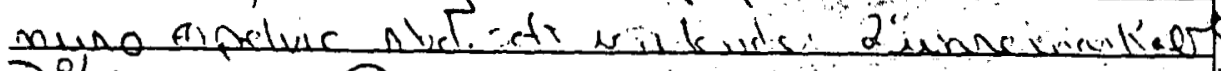

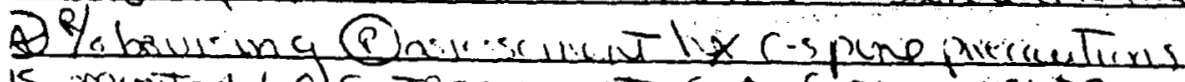

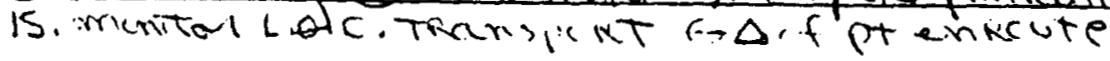

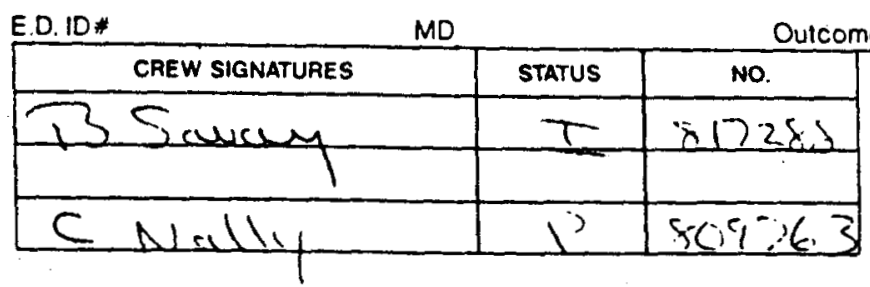
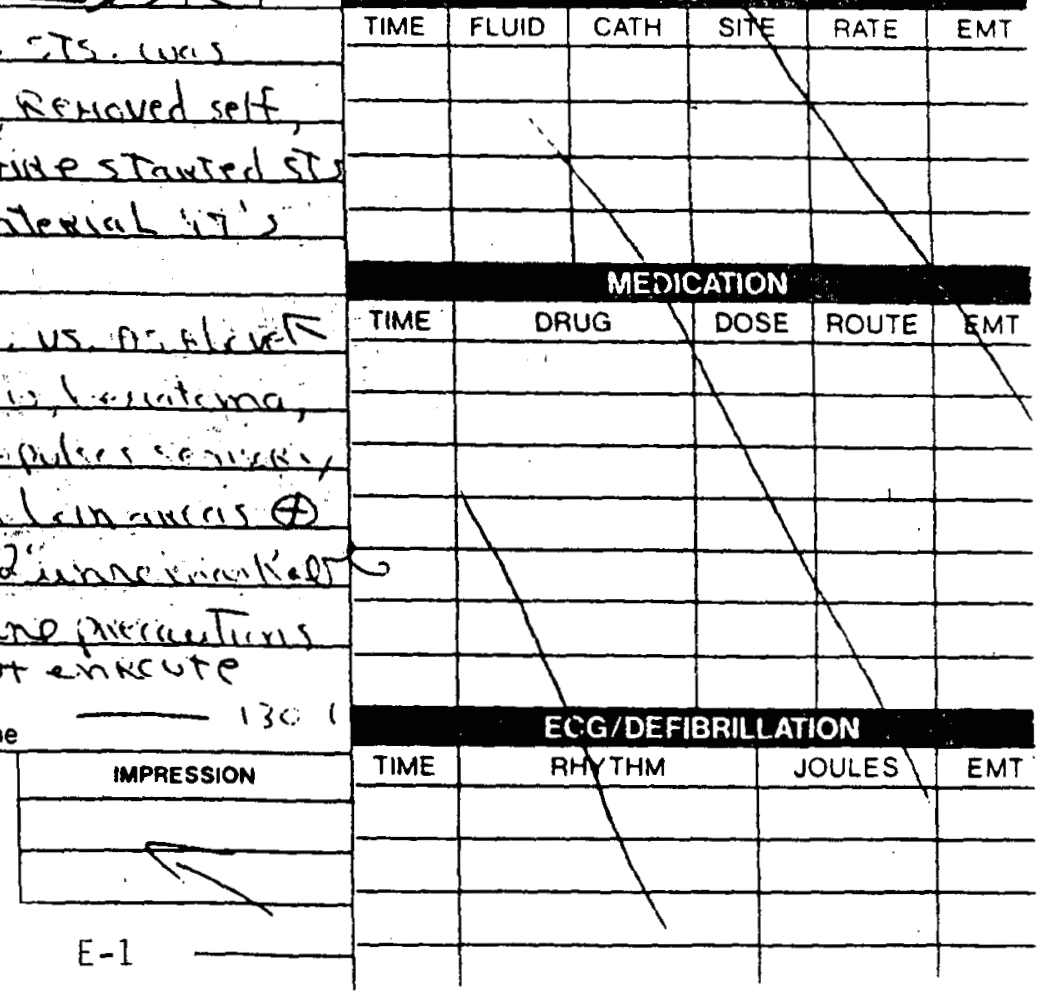
CE INC. U

202148 SP 22783 $\frac{27}{7.21 .64} \mathrm{Fa}$ ent Time unk hone Lat cian $\ln k$

\begin{tabular}{|c|c|c|c|}
\hline & \multicolumn{3}{|c|}{ VITAL SIGNS } \\
\hline IIME & B.P. & $P$ & A. \\
\hline 340 & $126 / 20$ & 132 & 20 \\
\hline 350 & $124 / 1$ & 128 & $2 v$ \\
\hline & . & & \\
\hline
\end{tabular}

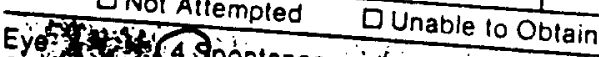

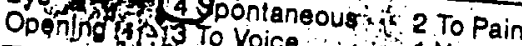

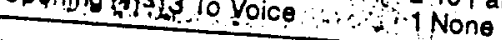

Verbal

Response 5 Oriented 3 Inapprop.

Motorilat6obedience

Respónsess 5 Purposeful

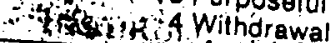

Coma Scale $(3-15)$

Add to Trálina sció

114[155011hit (s-4) (e.

Condition Pl Found
1 None

3 Flexion 2 Extension 1 None

$\mid \begin{aligned} & \text { Respiration } \\ & \text { Rate }\end{aligned}$

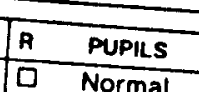
Normal $\square$ Constricted $\square$ Q D Reactive Q Reactive $\mathbf{0}$ $\square$ Not Reactive $\square \square$ Skin

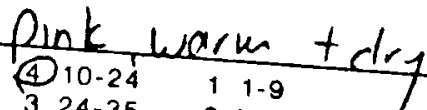

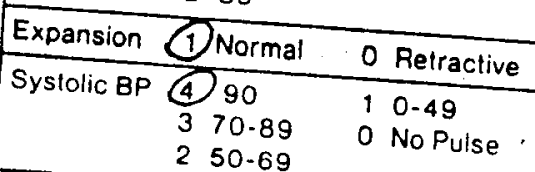

Capillary 6 Normal o None
Refill Total Trauma Score
EMERGIENCY MEDICAL SEF No. 91855

Date $12-16 \cdot 9)$ Amb. Co. (l) Quarters_- 25 Dispatched 324 Ar. Scene 332 Lv. Scene 347 Ar. Hospital $\geq 51$ Ret. to Service 400 Transport to Reason putocul Consult med wo 24 Hospital BSmC \& $R$

DUHF $\mathrm{CH} 4.1$ $\square \mathrm{VHF}$

Transmission Quality $\quad g_{u} e_{2}$ $02 \quad 5 \mathrm{~L} / \mathrm{m} \cdot \mathrm{CC}$ $1^{\circ}+2^{\circ}$ surver immub un lune baed philly wlber, o neck 2 d'Be!ts: 2" tape

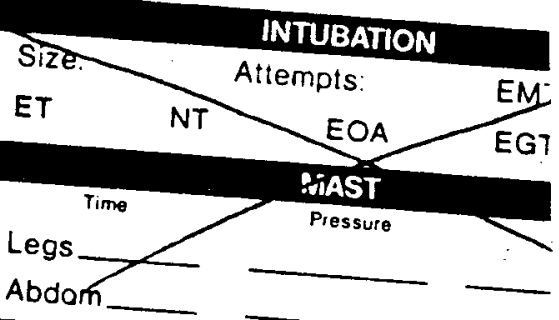
comments ClA : disorientet by bis car

(5)27 yo $\rightarrow$ appasently that stuck a tracto druer of a cat

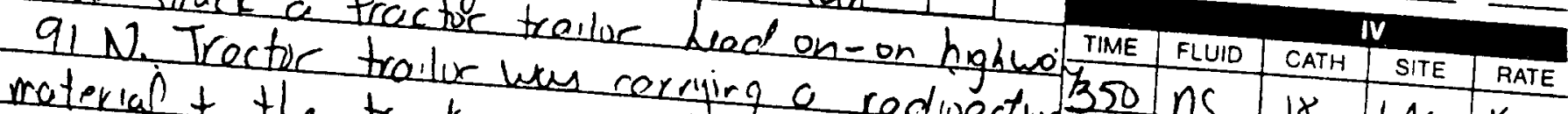

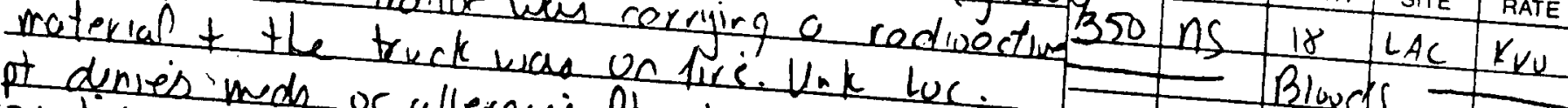

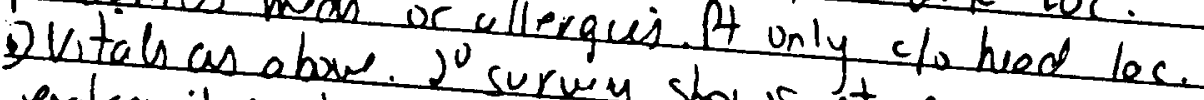
extremities loc air sury shows ot musing a 6

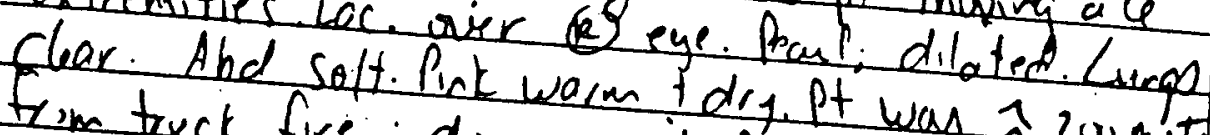

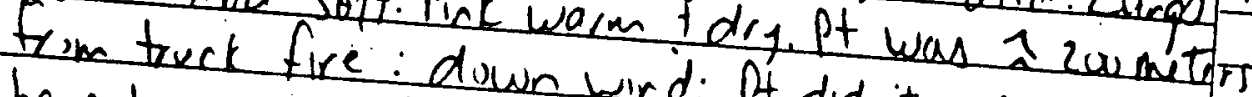
have beun errosed town wird: Pt didnt apean to

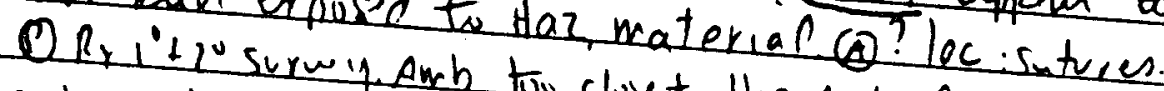

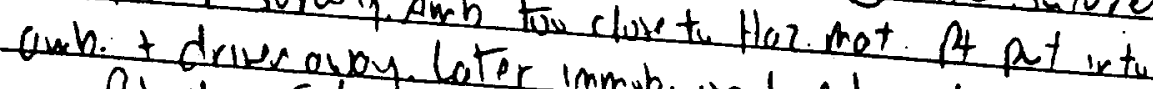

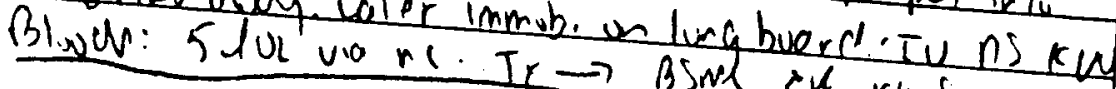
E.D. 10.

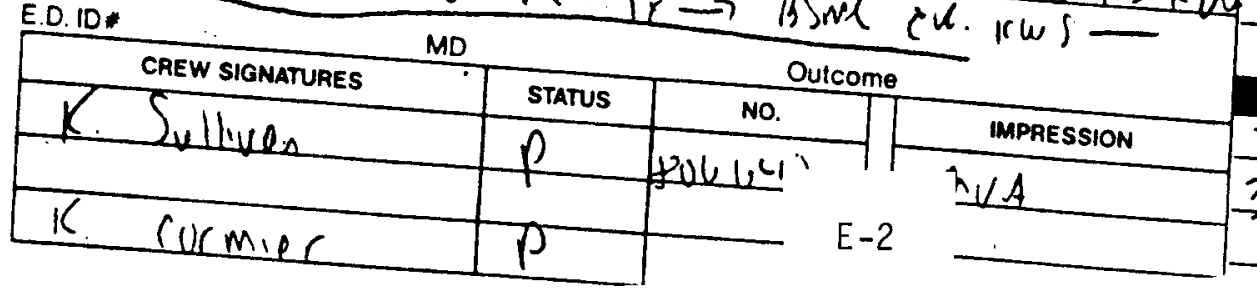

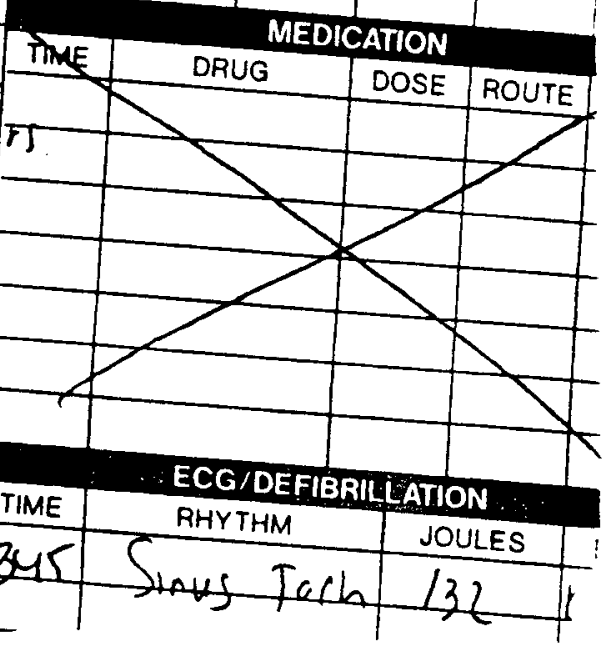




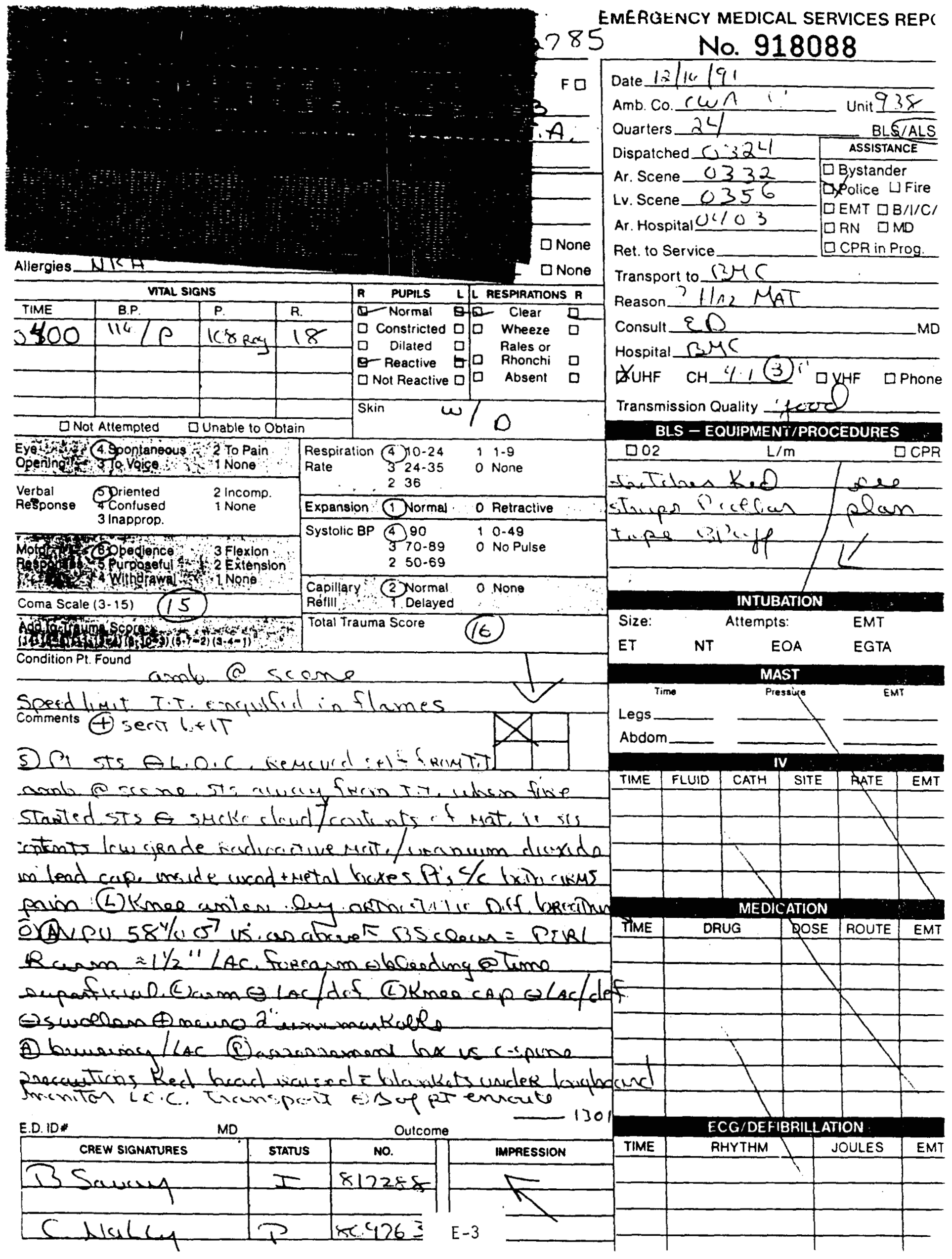


1) Dispatched to head on collision car vs tractor trailer in front of B sw on 91 Northbound

2) Took $291 \omega \rightarrow 91$ So. in order to check for placard

13) As we appraciched, we saw the truck folly engulf fed in flumes with no placard visible. Dispatch til.

4) Highwoywas blinked off@ Exit 7 so we took the init into W. Columbus to turn around and enter the un ramp in front of BSW

5) We made cur wiry ciround a feuvelicicles is som tinge debris in the road to the car involved in the accident (extensive front end damage).

6) We advised dispatch i Unit 38 of the fire i would advise on the number of patients as soon as we found out from ms

7) Bystander met is at scene, advised us of radioactive hazmat in truck 's he though there were 3 patients total.' 2 on, 91 Do

8) Next, the mss trooper approached as we were loading our ambulatory patient.

9) The trouper told us this was a hazmat is that we were downwind is should be more than 150 yards away. We were about 150 aw io) We sat the patient down on the kerch 's immediately left the area due to pussibl contamination is assessed the patient when we were safe.

11) As we were preparing to leave, we tried to Advise Unit 38 of the situation' that 2 patients ${ }^{2}$ es in a cruiser in, the 
1a) Patient wais Lispine immobilized, assessment alone.

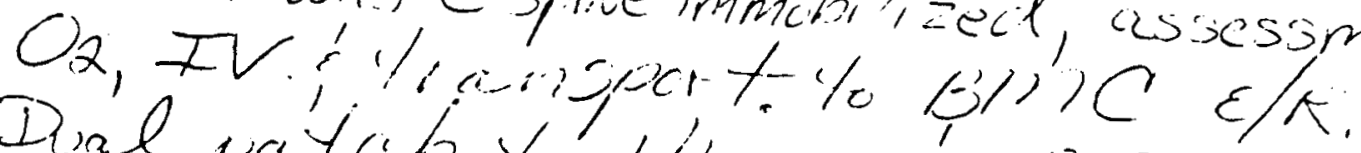

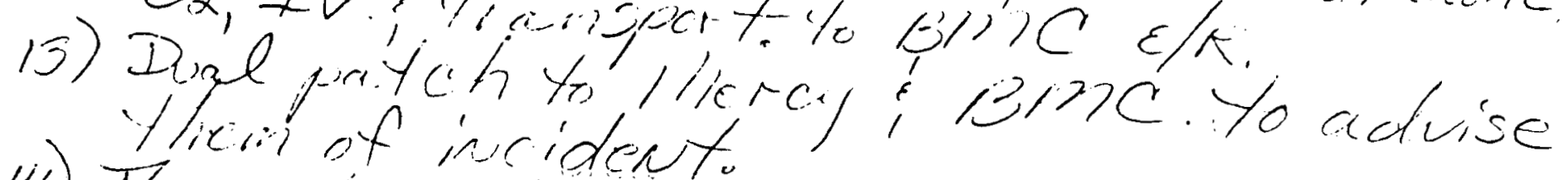
the racion of ineident.

14) The radiongtive materia luss unknown intil the heipital found out about $\frac{1}{2}$ hour

$E-5$ 
O Respunet To scent VIA N/B 91.

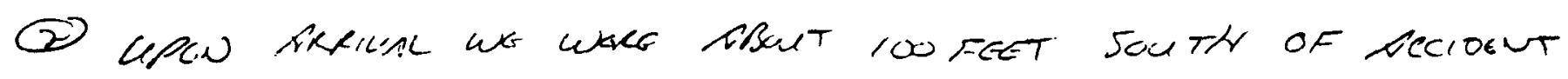
c wino Goren EXTT.

(3) Truck Fuccy ENGento in Fangs.

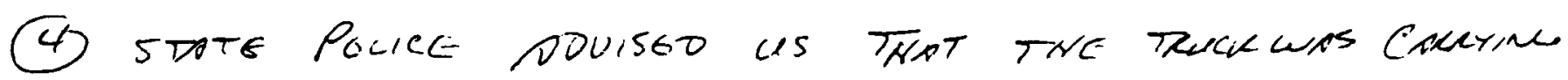
Rozrontiue Fuec.

(5) Stite Pouce Touo us to Prick cuk Riginget. DNo wrik

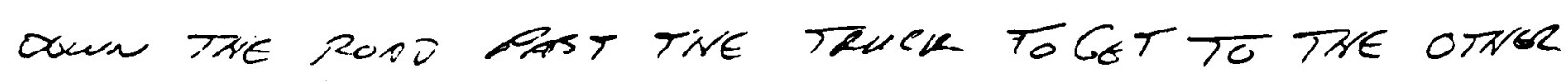
295 .

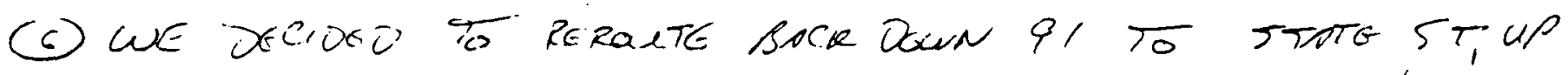

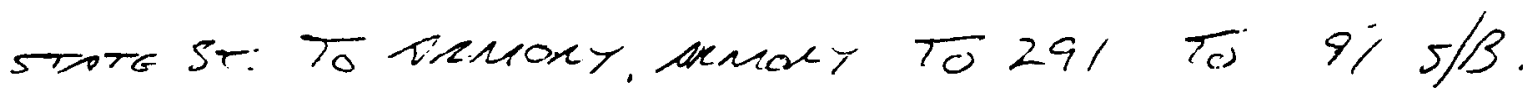

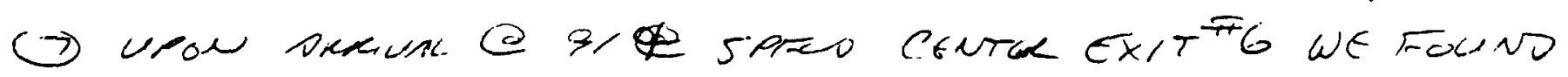

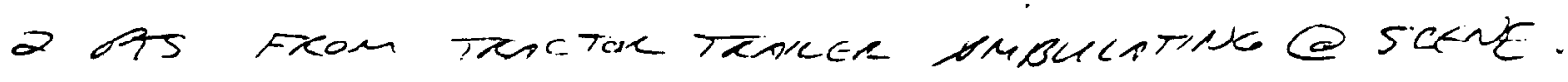

Trentar of Trous To BuCER UIA RT:STOSTTY OUT OF HOT zONE.

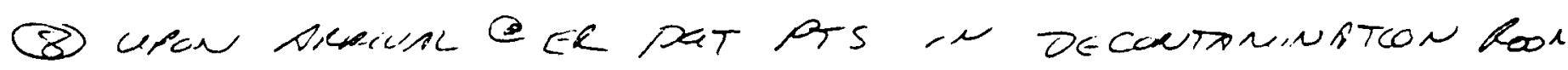

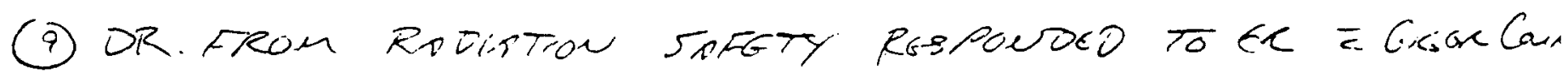

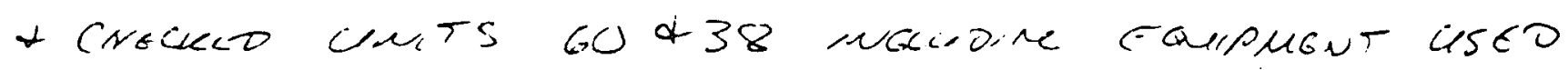

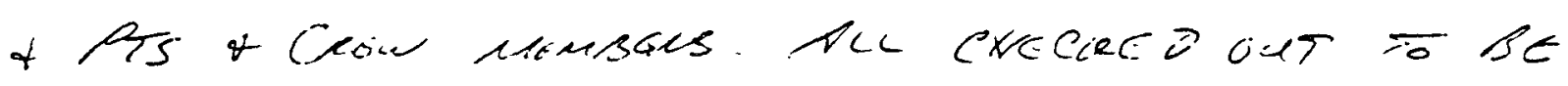
cucontrmuret.

$E-6$ 


$$
12 / 16 / 9191 N \text { HAZMAT }
$$

(DISPATCH)

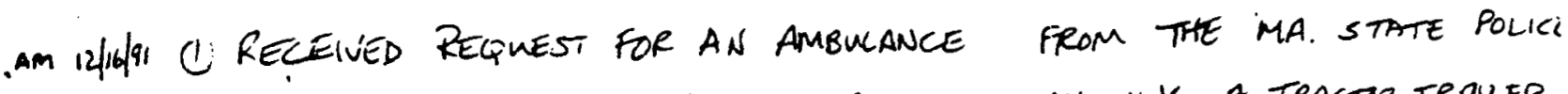

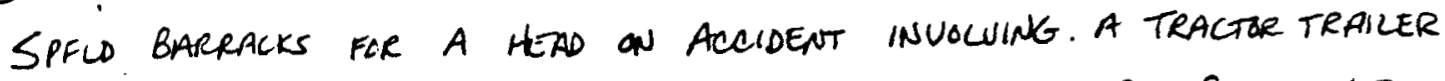
AND A CAR IN THE REAR OF BAY STATE WEST ON RTE 91 NORTH BOW UL they also stated that the tractor trailer unit was on fire an ENGULFED IN FlAMES.

(2) DISPATCHED UNIT 60 From 25 (K. SULLIVAN/K. DoRmER)

Dispatched unit 38 from 24 (C.NALLY/B SANDY)

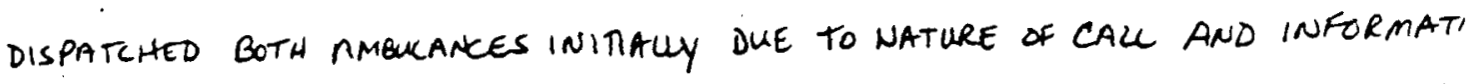
received that I interpreted to possibly mean multiple pattóts w TH PROBABLE MULTILL/SERLIOIS NATURES

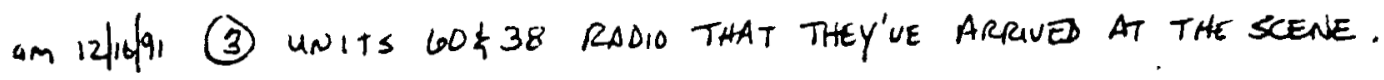

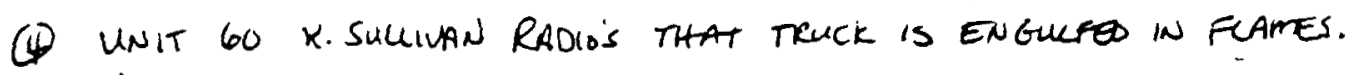

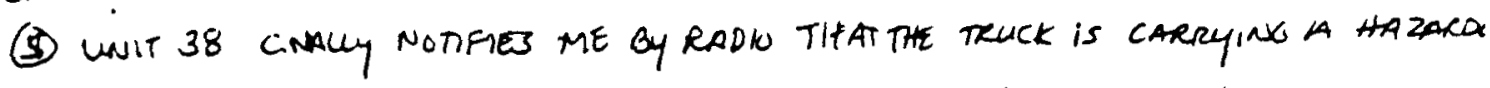
material and to call the fire dept to notify THEM of a hazmat situla.

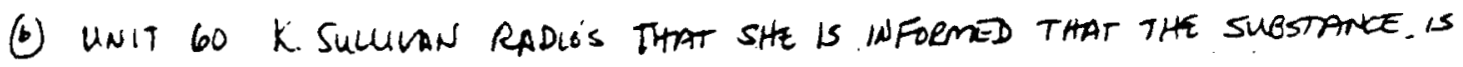
Radio active in nature and requires to pane pere at least iso feet

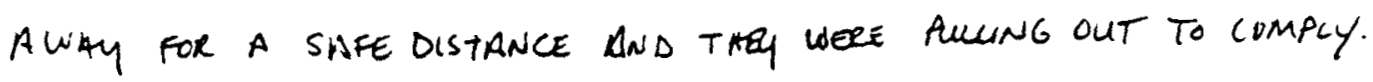
(1) UNIT 38 Notified of same and followed same.

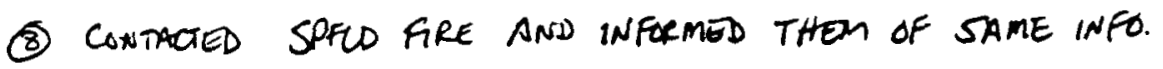

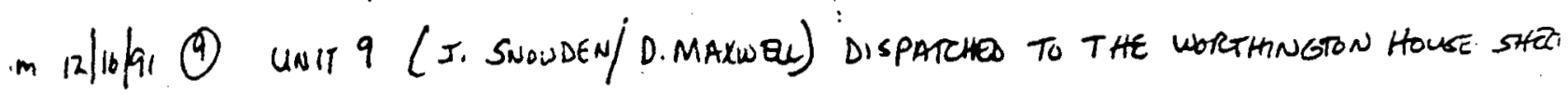

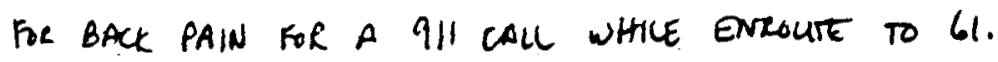

(10) UNIT 6 (D. REPIN/P. BUDAJ) DISPATCHED to 61 From 23

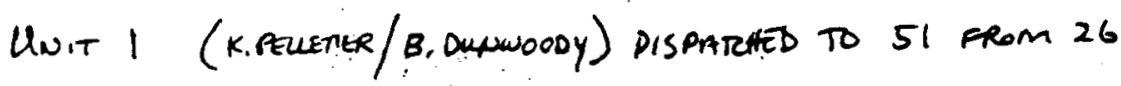

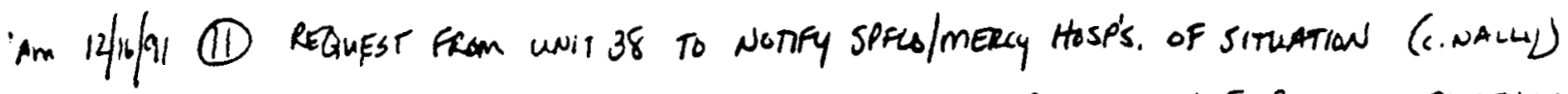
So they may prepare for possible radiation exposure patients

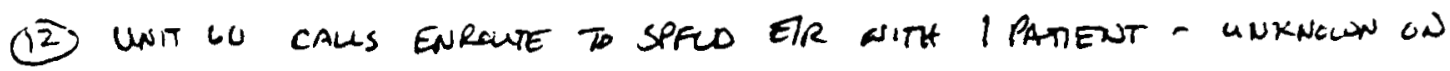

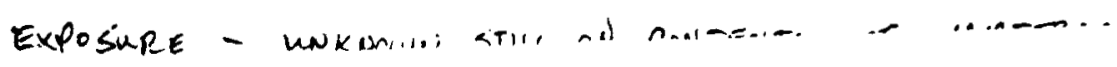

$E-7$ 
(13) SW ITHED UHF RADIO FrON HES 9 TO MES 4 IDENMEYPUE MYYSELF AS

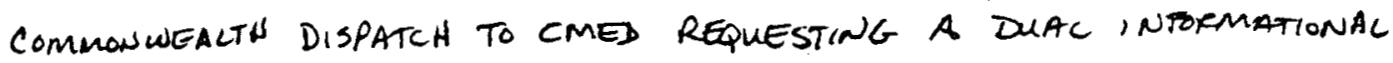
PATCit TO THE SPFL \& mERCY ER'S. CMEO DO SO SETINiE ME UR ON

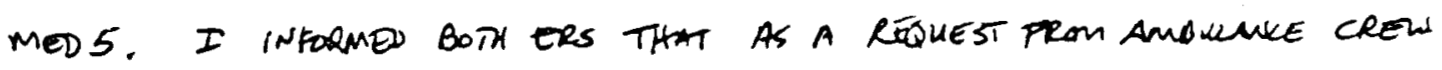
AT THE sceane of AN ACCIDENT I WAS NOTFYING THEM IN ADUANCE OF A Possible radiation Exposure from an cundetermutes reado actule

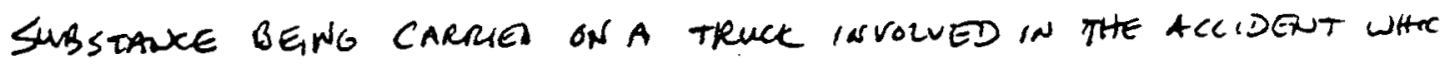
WAS Now BURNING, SO THAT THEY maY PRePare GOR SAME. I ALS. INFORMESS THEM THAT AT THIS POINT INJURLES WERE CONTAINEDT just the three victims of the accident and tNuturies were con SISTENT From THE ACUSEWT. THAT THERE WERE NO APPSTRENT RADIATT. INJURIES REPORTED YET AND IT WAS STILC WUDETERMINED IF TITEY HAD BEES EXPOSED.

(4) NoTfFed unit $38+$ unit 60 of notification Completed

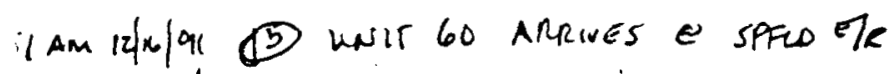

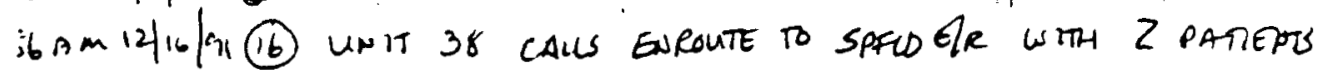

(17) CONTACTED SPFL Fire to DETERMINE STATUS OF HaLmAT. INFORMED It was a level 1 haL mat $\$$ command post/STaGing area WAS ON VERNON ST.

(18) DISPARIES UWIT 9 From MERYY EK. AFTER COMPLETION OF THERE CALLTo stand-by on vexnon ST. WITH Command post.

BAM 12/k/9 (10) UNIT 38 arRives 2 SPFID tR

(20) Contacte bub turner I dane clark rebarding same and they BOTH RESPONDES TO WORK.

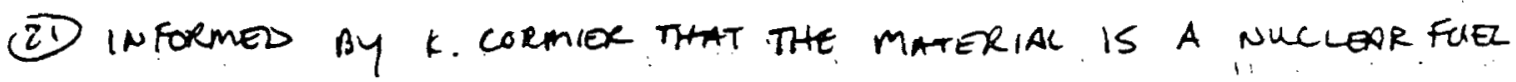
NAMED URANIUM DIOXIDE.

222 ReMPINDER of TIME SPENT WTH AN AMBUCANCE IN STAND-BY

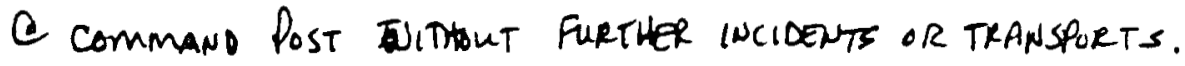




\section{APPENDIX F \\ City of Springfield}

Integrated Hazardous Materials Incident Reponse Plan 
Plan Revised Feb. 28, 1990

Replaces September 30,1988

Telephone Numbers Revised 11/30/89

\section{CITY OE SPRINGEIELD \\ INTEGRATED HAZARDODS MATERIALS INCIDENT RESPONSE PLAN}

(SARA Revisions, October 1988)

\section{PURPOSE}

This plan is intended to establish an integrated operating procedure for the various City Departments and Agencies in: responding to a hazard materials (HAZ-MAT) incident. The interface of State, Federal, and private resources are also reviewed. Where applicable legal citations are listed. These procedures are prepared to assist all responding agencies to understand their own responsibilities and those of the other agencies.

\section{NOTIFICATION}

2.1. ANY DEPARTMENT determining that a haz-mat incicent is suspected or in progress SHALL immediate!y communicate suct. information over the radio or telephone in clear ianguage to their dispatcher who will immediateiy notify $9-i-1$.

\section{9-1-1 SHALL BE THE PRIMARY ACTIVATION OF THESE PROCEDURES.}

2.2. Such communication shall include:

2.2.1. Identification of HAZ-MAT call. "I ali a ceportirg yaMAT incident."

2.2.2. The location of the incient.

2.2.3. The type of situation found. (tank truct-auto acoidest. industrial incident, unknown fumes, etc.) and jevei gt response.

2.2.4. The identification of the hazardous material, if kaown-use DOT placard number, shipping manifest, etc.

2.2.5. To the extent possible further describe tie scene situation, particularly, for casualties, wird, smoke, noises, odors etc.

2.2.6. (Facility's calling 9-1-1 are requested to lise contalt procedures as approved by the Local Energency ? annirg Committee) See Appendix $F$ 
90.02 .28

2.2.7. The 9-1-1 operator when determining that caller is describing a haz-mat incident shall obtain the address and ask the caller to stand by to be transferred to the Fire Department. The operator shall monitor the call and immediately notify the Watch Commander. The 9-1-1 operator shall also advise contracted ambulance service, via the ring down line, of the call and to stand by for a haz-mat response and for further instructions.

\section{RIRST RESPONDER CONSIDERATIONS}

(Police, Fire, Ambulance and others)

3.1. The first responder has a critical responsibility to initiate the City's response to a Haz-mat incident. His/her responsibility shall be:

3.1.1. Confirm and Assess situation

3.1.2. Notify Dispatch immediately with confirmation and whether it is a LEVEL 1 or LEVEL 2 incident.

THEN

3.1.3. Isolate incident preventing access to scene and orter those already there to evacuate scene.

3.1.4. Do not attempt to rescue victims from contaminated area unless properly equipped to do so.

3.1.5. After isolating area, render medical aide to viatias who are outside contaminated area.

\section{FIRE DEPARTMENT OPERATIONS}

4.1. The Department shall follow accepted its rules and regulations.

4.2. Procedure Summary:

4.2.1. Dispatcher's Duties.

4.2.1.1. Upon initial receipt of an reported emergency HAZMAT incident, the on duty operator shall:

4.2.1.1.1. Dispatch first due pump and truck company according to the box assignment, the District Chief, Pump 7, Truck 1, the Rescue Squad, and Hazmat 1.

4.2.1.1.2. Obtain wind direction from either Westover AF?, Bradley, or the next available source, and transmit this information to 31 ! responding companies. 
4.2.1.1.3. Advize reaponding District Chief if response is to a SARA facility.

4.2.1.1.4. Ring back Police to advise of the HAZ-MAT incident call and request that they institute their HAZ-MAT procedures.

4.2.1.1.5 Request the following personnel respond when a LEVEL TWO or greater response is declared:

Chief

Deputy of Suppression

Training Division (DC Cassanelli and Capt. El1iott)

Public Relations

Arson Squad

4.2.2. Upon receipt on a non-emergency report from a SARA facility the duty operator shall transfer the ca!: to tree District Chief whose district the facility fall into.

4.3. First Responding Company:

4.3.1. Size up situation by:

4.3.1.1. Determining the magnitude of the incident and establishing level of response.

4.3.1.2. Determining the identification of the material, if able to do so from a safe and up wind location.

4.3.1.3. Assistance needed for control.

4.3.1.4. Wind and topographical considerations.

4.3.1.5. Communicate via radio the above finding imediate:?.

4.3.1.6. Estabiish a preliminary HOT ZONE: Evacuating as necessary. The evacuation of the HOT ZONE shal: be done with Fire personnel who are properly equiped ts do so. A thorough search of the HOT ZONE shali be done to insure that all are removed from the zone.

4.3.1.7. Advise incoming units of safe areas.

4.3.1.8. Senior Fire officer shall become INCIDENT COMMANDEF until relieved.

1.3.1.9. All apparatus shall be placed facing away from incident.

\subsection{First Responding Chief Officer:}

4.4.1. Shall assume the INCIDENT COMMANDER(On Scene Coordinato:) position, and: 
4.4.1.1. Egtablish a COMMAND POST/Incldent command system at a safe distance from the incident site, assume control of the incident operations from the COMMAND POST, and direct Fire and other personnel until such time as the incident is terminated or relieved. Communicate the COMMAND POST's location to all responding units.

4.4.1.2. Designate a Fire Officer as the HOT ZONE commander until replaced by Capt. D. Elliott for Fire Department operations within it.

4.4.1.3. Designate a Safety Officer until replaced DC Cassanelli to oversee operations and report directly to the INCIDENT COMMANDER.

4.4.1.4. Designate a recorder for the COMMAND POST to record and confirm actions and orders given at scene. Chief's aide will be the interim recorder.

4.4.1.5. Take what ever actions that seem applicable to contral the spread of the spilled, leaked or released material and reduce the hazard of fire or other causes of damage to persons or property.

4.4.1.6. Insure that the HOT ZONE, INNER PERIMETER, HARM ZONE, OUTER PERIMETER, DECONTAMINATION and STAGING AREAS are established and communicated to responding agencies

4.4.1.7. If responding to a SARA covered facillty, obtain contingency plan envelope from Command Post or taznot Unit Eiles. Envelope will include, evacuation zone considerations, facility inventories, MSDS info, floor plans-photographs, and emergency contact names and telephone numbers. A facility representative should be assigned to the COMMAND POST. Advise Alarm and Police if Facility is covered by SARA.

4.4.1.8. Obtain latest weather report, and keep it updated.

4.4.1.9. Insure that all necessary evacuations have been ordered and completed.

4.4.1.10. Insure that a licensed clean-up contractor is callad to scene to clean up and remove all contaminated materials. Work with DEP personnel as necessary to see that the above is completed.

4.4.1.11. Insure that appropriate agencies estabish comand presence at the COMMAND POST. 
4.4.1.12. Appoint an Incident Public Information officer(PIO)

to coordinate and direct the release of information

to the media concerning incident. Advise all

responding agencies that ONLY the PIO will release

information concerning the situation. The

Evacuation Control Group PIO will coordinate

evacuation information needs with Incident PIO.

4.4.1.13. Insure that a PRESS AREA is established and made known to Police Supervisor and PD Headquarters. Press will not be allowed outside the press area wthout the permission of Public Information officer.

4.4.1.14. Insure that responding City Departments are aware of their responsibilities. SEE APPENDIX A

4.4.1.15. Institute coordination with abutting municipalities, if appropriate.

4.4.1.16. Insure that communications have established with CHEMTREC and/Or NATIONAL RESPONSE CENTER (NRC). NR: notification is required by SARA Regs. for SAFA Covered facilities.

4.5. Hazardous Material Unit shall follow its procecures as adopted in Notice March 22, 1389.

\section{POLICE DEPARTMENT OPERATIONS}

5.1. The Department shall follow its accepted rules ind regulations.

5.2. Procedure Summary:

\subsubsection{9-1-1 Operator:}

5.2.1.1. Upon receiving a call in which he/she believes is confirmed or a potential haz-mat call, the operato: shall:

5.2.1.2. Obtain the address of the incident and cail back number.

5.2.1.3. Transfer the call to the Fire Alarm Center.

5.2.1.4. Monitor Fire Department-caller discussion.

5.2.1.5. Notify Dispatch of call.

5.2.1.6. Advise all other 9-1-1 operators of the HAZ-MAT Ea: :

5.2.1.7. Notify Wateh Commander of Call. 
5.2.1.8. Alert ambulance service to stand-by.

5.2.1.9. Notify DPW Yard of incident and advise DPW to contact Bondi's Treatment Plant.

5.2.1.10. Upon termination of incident submit a report to the Chief of Police through the Watch Comander on actions taken, problems encountered, etc.

\subsection{Radio-Dispatch}

\subsubsection{Unconfirmed Haz-mat Call}

5.3.1.1. Dispatch District Car and Street Supervisor to investigate the call.

\subsubsection{Advise Communication's Supervisor}

5.3.2. Confirmed Haz-mat call.

5.3.2.1. Advise all units of level of call.

5.3.2.2. Advise Communication's Supervisor

5.3.2.3. Dispatch District Car and Street Supervisor to incident. Determine from Eire Alarm if a HOT or WARM ZONES have been establistied.

5.3.2.4. Determine from first responding car situstion report.

5.3.2.5. Obtain cars for perimeter security as needed by Street Supervisor.

5.3.2.6. Maintain car location log or aap of road block locations.

5.3.2.7. Assign Police radio traffic related to inciaen: $=$ a specific channel.

5.3.2.8. Upon termination of incident submit a report to tha Chief of Police through the Watch Commander on actions taken, problens encountered, etc.

\subsection{Watch Commander.}

5.4.1. Unconfirmed Haz-mat Call.

5.4.1.1. Insure that Street Supervisor and District are assigned to investigate incident.

5.4.1.2. Insure that $9-1-1$ has alerted contracted ambulince service and DPW yard. 
5.4.1.3. Ageign driver to COMMAND POST and have it ready to respond to incident.

5.4.1.4. If call is determined to be unfounded or leve! une, advise Ambulance, DPW, and COMMAND POST Driver.

5.4.1.5. If call is determined to be a level two or above, see next Section b.

5.4.1.6. Determine if location is a SARA covered facility.

5.4.2. Confirmed Level Two or Three Haz-mat calls.

5.4.2.1. Determine from Fire Alarm or Police on scene, location of HOT ZONE and establish INNER PERIMETE?

LINE security needs. Also an interim situation report.

5.1.2.2. If location is a SARA covered facility, obtain Facility File and review response considerations section.

5.4.2.3. Order command van to respond to COMMAND POST site: established by Fire or SARA plan, if not, an inter:m site.

5.4.2.4. Order Records Bureau to contact those on the emergency personnel list and report back contacts made.

5.4.2.5. Insure that 9-1-1 has notified Contracted Ambusinas Service and DPW Yard of call.

5.4.2.6. Order a Superior officer to the Command pos? and establish a Police comand prestrice.

5.4.2.7. Advise Radio of situation and request ayailible resource list.

5.4.2.8. Verify that the Chief and Deputies have been. notified.

5.4.2.9. Confirm the activation of the Tactical Respense Unit Command Group.

5.4.2.10. Determine WARM ZONE location, and establish OUTER $\&$ INNER PERIMETER LINES security needs.

5.4.2.11. Order Police personnel to secure INNER and OUTER PERIMETER LINES and to alluw no one to pass through them without the permission of scene COMMAND POST.

5.4.2.12. Determine STAGING AREA locations for incoming resources. 
5.4.2.13. Advise all incoming resource departments if ACCESS CONTROL POINTS have been established.

5.4.2.14. Assign two detectives to the Street Supervisor for any potential eriminal and/or epidemiological investigations that mabe ordered.

5.4.2.15. If necessary, activate Tactical Response Unit.

5.4.2.16. Advise abutter municipalities and state police, if appropriate.

5.4.2.17. Wait for further info and requests from street/?R: Supervisors.

5.4.2.18. Advise contracted tow truck company to have a unit to stand-by.

5.4.2.19. If necessary, prepare messages to be broacuast by Continental Cablevizion using the emergency access system.

5.4.2.20. Upon termination of incident submit a report to Chief of Police on actions taken, probiems encountered, etc.

5.5. Street Supervisor

5.5.2. Unconfirmed Situation:

5.5.1.1. Respond and investigate call and report lavel of response to Radio and Wateh Commander.

5.5.1.1.1. See First Resporder consideratiors if Superior Officer is first to artive on szing.

5.5.1.2. If LEVEL 1, Establish CP with Car and ingure that sufficient Police personnel are avaijubia, asil $f z$ COMMAND POST if requested by Fire.

5.5.1.3. If LEVEL 2 or 3 , see next section b.

5.5.2. Confirmed LEVEL 2 or 3 incident.

5.5.2.1. Determine COMMAND POST Location from Fire on Scone or Watch Commander, and report te it and assume command of responding Police resuurces urt: : relieved.

5.5.2.2. Determine status of situation, and location of 40 ? and WARM ZONES, and INNER AND OUTER PERIMETER LINES. Insure that sufficient Police resources are available to secure areas. 
5.5.2.3. Insure that a communications officer, $a$ perimeter/command post security supervisor are assigned to COMMAND POST.

5.5.2.4. Advise Police $\mathrm{HQ}$ and OUTER PERIMETER LINE Police personnel of press area and the name of public info spokesperson.

5.5.2.5. Establish if necessary ACCESS CONTROL POINTS to WARM and HOT ZONES in consultation with INCIDENT COMMANDER.

5.5.2.6. Assist INCIDENT COMMANDER with tasks as requested.

5.5.2.7. Keep Police HQ informed of situation status.

5.5.2.9. Assign WARM ZONE security. in consultation with INCIDENT COMMANDER and COMMAND POSi.

5.5.2.9. Start evacuation of WARM ZCNE areas if directei : by INCIDENT COMMANDER until rej zeved by a Evacuation Control Group. HOT 20NE will be responsibility of Fire Department.

5.5.2.10. If necessary, activate a Evacuation Control Graze. See Section 4 for Evacuation Control Group.

5.5.2.11. Provide food, drink and necessary relief to officers on perimeter security lines.

5.5.2.12. Assign Police Officer to She!ter Managers fir Eat: shelter opened for security and comunications.

5.5.2.13. Order a thorough search of WARM ZONE if Li:ected by INCIDENT COMMANDER to insure that no unauthorized persons are in it.

5.5.2.14. If applicable, assign morgue security in conjunction with Medical Examiner.

5.5.2.15. Upon termination of incident submit a report to the Chief of Police through the Watch Commande: on actions taken, problens ercountered, its.

5.6. Evacuation Control Group:

5.6.1. Activated by Street Supervisor or Watch Comanite, t:e Group shall consist of :

5.6.1.1. Evacuation Control Officer

Responsible for overall supervision of group. determining priority of areas to be eviziated, insuring that INCIDENT COMMANDER and COMMAND POE: are kept informed of the status of the Evacuation. 
90.02 .28

5.6.1.2. Eublic Information Coordinator

Responsible for Evac Group public information

announcements concerning: evacuation warnings,

areas being evacuated, evacuation routes if

established, shelter locations, general

information needs. Shall also keep watch

Commander informed as to the Cable messages that

should be transmitted via the cable system.

Evacuation PIO shall keep the Scene PIO informed of information given to media and any special needs of the Evac Group.

5.6.1.3. Communications Coordinator/Recorder

Responsible radio communications and for.

maintaining a $\mathrm{log}$ of areas evacuated, resources used, etc.

5.6.1.4. Safety officer, if warranted.

Responsibie for keeping Evac Group personrel

aware of potential dangers, and to monitor the issuance and use of personal safety equipment.

Shall keep Scene Safety officer informed of $3 r ;$ problems or situations encolintered by the Evac Group resources, incluting Police, Bus transportation, Emergency medical services, $E$ other personnel assigned to the evacuatien process.

5.6.2. Determine if personal protection needs for officers, and advise all officer to turn $A C$ on Mar. If persinal protection equipment is used, appoint safety officer ts monitor its use.

5.6.2.1. Respirator filters shall be collected and treated as hazardous material for proper disposal.

5.6.3. Control group determines sequence of area(s)to be evacuated and route(s) to be used for evacustion.

5.6.4. Advise media representatives at PRESS AREA of media needs of Evacuation Control Team. Depending on situation advise media to start pre-warning announcements and what individuais should take with them if evacuated. Medicines, blankets, clothes, etc. Advise neighbors to contact those individuals in their neighborhood that are elderly, disabled, or hearing or sight impaired to be sure that they are aware of situation. Advise Watch Commander of Cable override requirements and information needed to be transmittei. Ask local TV media representatives to provide script overrides of evacuation messages. 
90.02 .28

5.6.5. Deteruine epecial needs situations: (See map in File) Schools

Hospitals

Nursing homes; day care facllities; group homes; gubila facllities; special events--festivals, sporting events, concerts; major employers.

Municipal Hospital Priority shall be given to special

needs persons during sheltering operations.

5.6.6. Request Spanish speaking officer to be assigned to evacuation group. An interpreter for the hearing impaired should be requested to respond to the Evac Control Group area.

\subsection{EVACOATION PROCESS-RESIDENTIAL AREAS}

5.7.1. Media announcement of areas recommended to be evacuated. Evac Group PIO shall advise media of areas being evacuated and of pre-warning messages that are deemed appropriate to be broadcast. Shail advise the Watch Commander of need for Cable override messages f: : the cable system.

5.7.2. Street by street by cruiser PA giving warniag and shelter location (Municipal Hospital) and Evacuatio: direction.

This is the Police. An emergency evacuation has bes declared, evacuate to (shelter name/location) via - For energency

transportation please call

sure that your neighbors are alerted.

5.7.2.1. Cruiser shall stop in the street at :easudita distances and give a 10 second aiert tore, tha the evacuation message. Fire apparatus miy assist with process. Upon completing a st:aet. the cruiser shall inform the Eyac Controi Grous that street is warned and proceed to next assigned street.

5.7.3. Obtain resources to move persons with special needs.

Transportation resources--

5.7.3.1. Ambulance services for chair-cars and vans. 5.7.3.2. PVTA Buses. 5.7.3.3. Travel Time Bus Co.

5.7.3.3.1. Bus transportation supervisor shou:a be reguested to be assigned to the Evac Contral Group. 
5.7.3. Houge by house notification by street. (Fire companies should be considered to assist). To extent possible only uniform personnel should be used in the house by house notification process. At the completion of a street, the officer shall advise the Evacuation Cont:cl Group that the Street has been warned and proceed to the next assigned street.

5.7.5. Advise COMMAND POST as areas are evacuated.

5.7.6. MUNICIPAL HOSPITAL is to be used unless otherwise specified as the Shelter for neighborhood residents. (use Main entrance on State St.) Secondary shelter locations in order of priority are:

Central High School

Commerce High School

New North School

Kiley Jr. High School

Van Sickle Jr. High School

All the above have emergency electrical power.

5.7.7. When school is in session, schools should be used only as a last resort. Civic Center should be considered as an alternative.

SPECIAL NEEDS PERSONS SHALL BE SHELTERED AT MONICIPAL HOSP.

5.7.8. Determine from INCIDENT COMMANDER when it is safe allow the return of evacuees to WARM and HO? ZONEE.

5.7.8.1. Arrange for media announcements of areas being allowed to be re-entered.

5.7.8.2. Arrange for transportation needs for persens is shelters needing rides howe.

5.7.8.3. Determine from shelter managers when sheiters ire secured.

5.7.9. Jpon termination of incident submit a report to Watch Commander on actions taken, problems encountered, et:.

5.8. First Responding Officer

5.8.1. See First Responder Considerations if Cruiser is first to arrive.

\section{EMERGENCY MEDICAL SERVICES OPERATIONS}

6.1. The contracted ambulance service shall institute Mass

Casualty Response Plan as approved by the EMs Comission, Eebruary 15, 1984 . 
90.02 .28

\subsection{Procedure Summary:}

6.2.1. Contracted Ambulance Dispatcher, shall:

6.2.1.1. Designate two ambulances for initial response or stand-by. Move Medical Control info case onto a designated response ambulance.

6.2.1.2. Determine from Fire Alarm the situation at scene, the location of the Command Post and EMs Staging Area (if designated), and wind Direction, whether it is SARA Facllity.

6.2.1.3. Dispatch two ambulance to location specified by Fire Alarm operator.

6.2.1.4. If the location is a SARA facility the Contingen:y Plan shall be followed and information relayed to the responding units.

6.2.1.5. Alert other city ambulance services to stand by further information.

6.2.1.5.1. Activate back-up ambulances in accordance with EMS Call Up System.

6.2.1.6. Coordinate with first arriving ambulance and C-MED to obtain EMS Resources.

6.2.3. First Arriving Ambulance Crew:

See First Responder Considerations if Ambulance is first to arrive; if HOT ZONE is already established:

6.2.4. Senior EMT Lpon arriving at scene shall:

6.2.4.1. Report to COMMAND POST as EMS COMMANDER and take control of EMS resources at scene and obtain a briefing of situation as it is curzently known.

6.2.4.2. Coordinate with contracted service dispatcher and CMED to obtain needed EMS resources.

6.2.4.3. Determine personal protection considerations for EMS personnel at scene and advise hospitals. Appoint Safety officer for EMS personnel if personal protection equipment is issued. EMS safety of icer will report to Fire Safety officer.

6.2.4.4.. Assign other EMTs as medical communications officer, and order him/her to advise contracted Dispatcher and Hospitals of situation at scene. The report should include if known, the following information: 
6.2.4.4.1. Description of incident

6.2.4.4.2. Number and type of known casualties

6.2.4.4.3. Description of haz-mat substances if known

6.2.4.4.4. Need for additional EMS resources

6.2.4.4.5. Location of STAGING AREA, OUTER PERIMETER and ACCESS CONTROL POINTS

6.2.4.5. Should situation warcant it, following functions will be assigned:

6.2.4.5.1. EMS Commander

6.2.4.5.2. Communications officer

6.2.4.5.3. Triage Officer

6.2.4.5.4. Transportation Officer

6.2.4.5.5. Safety Officer

6.2.4.6. Contact C-MED for a all-hospital pateh to advise then of EMS COMMANDER's identification and scene situation.

6.2.4.7. Should situation warrant it, request that C-MED obtain from Hospitals their capacities and a designated medical control contacts.

6.2.4.8. Assist INCIDENT COMMANDER in obtaining any information or assistance needed.

6.2.4.9. Stay at scene until relieved by a contracted ambulance service supervisor or designee, or nejejusi back into service by the INCIDENT COMMANDER.

6.2.4.10. Determine from Poison Control Info Center, CHEMTREC, National Response Center, or Nuclear Incident Advisory Team (NIAT) appropriate decontamination procedures for victins. Coordinate with INCIDEN: COMMANDER to determine a location for the Decontamination Area. Advise Medical Triage officer of its location. Decontamination of individuals and equipment shall be done by Fire Department teams. See APPENDIX $D$ for Poison Control Info Center procedures

6.2.4.11. Advise all alerted or involved services when incident is terminated, and release them back into service. 
90.02 .28

6.2.4.12. In the event of a fatality, the SCENE COMMANDER and Police Commander shall be notified. A morgue area shall be established, and the Police shall be responsible for notifying the Medical Examiner and security of morgue area.

6.2.4.13. Maintain a written log of actions taken and orders issued by Emergency Medical Personnel. Log shall be turned into INCIDENT COMMANDER upon termination of the Incident.

\section{CIVIL DEPENSE OPERATIONS}

7.1. The Civil Defense Director shall comply with those provisions of the revised CIVIL DEFENSE EMERGENCY MANAGEMENT PLAN approved by the Mayor in January, 1985.

\subsection{Procedure Sumary:}

7.2.1. The Director upon arriving at scene shall report to the COMMAND POST and report to the INCIDENT COMMANDER. The following are the responsibility of the Civil Defense Director:

7.2.2. Coordinate City departments other than Police, Fire, and EMS. Per request of INCIDENT COMMANDER obtain additiona! resources from various city and non-city sources such as:

7.2.2.1. Additional communications equipment and personal.

7.2.2.2. Public buildings.

7.2.2.3. Transportation.

7.2.2.4. Shelter management teams and supplies.

7.2.2.5. Utilities.

7.2.3. If situation warrants it, coordinate evacuation, shet:e: and shelter staff needs, evacuees needs in cuoperation with the Police and American Red Cross.

7.2.4. Assist COMMAND POST in organizing information gathered it scene

7.2.5. If situation warrants it, recommend to INCIDENT COMManLER and Mayor's Office that a Disaster declaration be made.

7.2.5.1. In accordance with Mass General Laws all State and Local Resources can be activated.

7.2.6. Advise INCIDENT COMMANDER of need to consider operating on a sustained basis (LEVEL THREE). 
90.02 .28

\section{DEPARTMENT OF POBLIC MORKS OPERATIONS}

8.1. The Department shall follow its accepted rules and regulations.

\subsection{Procedure Summary.}

\subsubsection{DPW Yard Operator (or Senior Operator at Wastewater Treatment Plant):}

8.2.1.1. Upon receiving a LEVEL ONE Haz-mat call from POLICE, EIRE or CIVIL DEFENSE, the operator shall: .

8.2.1.1.1. Request a DPW supervisor to report to the Spill location.

8.2.1.2. Upon receiving a LEVEL TWO hazmat call:

8.2.1.2.1. Notify Senior Operator at Waste Water Tueatment plant of spill and material involvec, if not available by telephone use radio.

9.2.1.2.2. Request a DPW supervisor respond to the commane POST location.

8.2.1.2.3. Alert yard personnel of situation and hive a driver stana-by for sand truck.

8.2.1.2.4. Dispatch departmental resources (such as sani, barricades, etc.l to the scene as requested by the INCIDENT COMMANDER or DPW supervisor.

8.2.2. DPW Supervisor Assigned to COMMAND POST

8.2.2.1. 1. Upon arriving at scene, report to INCIDENT COMMANDER at the COMMAND POST ard take cont:o! DPi resources.

8.2.2.2. Assign a Job Number for Response.

9.2.2.3. Order those DPW resources to scene as directed by the COMMAND POST.

8.2.2.4. If situation warrants it, coordinate with MA DEW, the clearing of streets, including plowing, sanding, tree removal, etc.

8.2.2.5.. Insure that Waste Water Treatment Plant Senior Operator has been notified.

8.2.2.6. Insure that DPW personnel are aware of personal protection equipment needs, and ubtain from COMMAND POST equipment if needed. 
90.02 .28

\section{HEALTH DEPARTMENT OPERATIONS}

9.1. The Department shall follow its accepted rules and regulations.

9.2. Procedure Summary.

9.2.1. Health Commissioner or designee:

9.2.1.1. The Health Commissioner upon arriving at scene shall report to the INCIDENT COMMANDER at the COMMAND POST, and shall insure the following steps are taken:

9.2.1.1.1. Make prelininary public health risk evaluation, this assessment shall include:

9.2.1.1.1.1. Water Supply.

$9 \cdot 2 \cdot 1 \cdot 1 \cdot 1 \cdot 2$. Food Supply.

9.2.1.1.1.3. Environmental Issues.

9.2.1.1.1.3.1. Air contamination

9.2.1.1.1.3.1. Ground contamination

9.2.1.1.2. Establish communications with State and Ezceril Public Health Agencies to obtain additioni: information or equipment.

9.2.1.1.2. Assess by Field Survey as soon as practica: impact on those concerns found in Sectian 3.2.1.1.1-3, and report to the INCIDENT COMMANDER .

9.2.1.1.4. Advise Welfare Department of those areas wher= food or home contamination exist and need for replacement.

9.2.1.1.5. Assign Health Department staff to assist Po: : ce Department with epidemiological investigative aspects of the incident.

9.2.1.1.6. Assign Public Health Nurses to each shelte: opened.

9.2.1.1.6.1. Assist Red Cross in determinirg evacuees health problems and needz. 
90.02 .28

10. FOLLOH-OP CONSIDERATIONS

10.1. Critique

Within forty-eight hours after a haz-mat response, a critique shall be held to review the response and to consider revisions to this document. The Incident commander shall chair this meeting.

10.2. Stress Debriefing

Scene commander shall institute stress debriefing for emergency responders in consultation with Departmental leadership and Hospital personnel. Emphasis shall be placed on this matter in the cases involving deaths at the scene.

\section{REVISIONS TO PLAN}

Suggestions for revisions to this plan shall be submitted to the Emefgency Response Coordinators office for consideration. Telephone numbers are reviewed every three months, evacuztion consideration listings are reviewed at least once a year.

12. PLAN EXERCISING

This Plan shall be exercised at least four times a year. Exercising shall be done with the Command Post Staft and with field response perconnel. At least one exercise a year shall be a transportation accident rail or highway, the others shall snvolve SARA facilities. The Emergency Response Courdinator shall be responsible for organizing and scheduling exercises.

12.1. Attendence Sheets shall be maintained at the Fi:e Training Center. Sheet will indicate the Date, Exercise scenario, Attendees. 


\section{APPENDIX G Chronology of Events and Phone Records \\ Vermont Yankee Power Corporation}




\section{VERMONT YANKEE NUCLEAR POWER CORPORATION MEMORANDUM}

$\begin{array}{lll}\text { TO: File } & \text { DATE: } & \text { December 20, } 1991 \\ \text { FROM: R.E. Sojkaffor } & \text { FILE: } & \text { WYB 91/268 }\end{array}$

SUBJECT: December 16, 1991 Fuel Shipment Accident

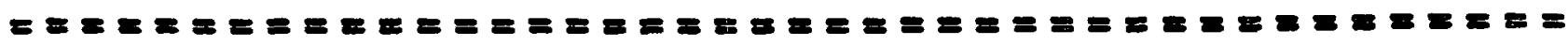

The following represents an approximate chronology of key events during the December 16, 1991 Fuel Transport Accident in Springfield, Mass.

12/16/91

0430 Vermont Yankee Control Room personnel called Bob Leach, who in turn called Chief Cartenelli at the Springfield Marriott.

0443 Control Room called Dave McElwee who alerted Mary Schneider and Bill Sherman Nermont)

0530 Leach arrived at accident scene with RP Monitoring equipment.

0615 TV 22 News Broadcast from the accident site and reported Vermont Yankee Nuclear was on the scene and that there was no radiation released.

0625 Sojka spoke with Jim Sinclair, Tom Schimelpfenig, Ed Lindamood Rick Lopriore and John DeVincentis(YNSD). Asked Sinclair to have Ed Porter get in touch with the Mass. CD center at the Marriott and offer Vermont Yankee's assistance and the others to meet in Vernon and Bolton as soon as possible.

0730.. Established Recovery Center in Vernon and began developing assistance and recovery plans, if needed at accident scene. Initiated W update. Notified NEPSCO of the potential need for a crane and trucking assistance.

0810 Vernon Recovery Center spoke with Mass. CD (Pappas) and Leach at Marriott and offered (to Leach) sending personnel and equipment to accident scene. Developed a recovery plan to move the fuel without the outer shipping crates to a nearby, unlicensed safe haven.

0830 Dean Weyman and Jim Sinclair departed from Brattleboro, VT for the accident scene in Springfield, Mass.

0900 Spoke separately to John Opeka (NU), Phil Bain (NU) and Harold Elchenholz (NRC).

0910 Established a multi-agency telecon with several representatives of DOT (Al Roberts, Chrls Smith), NRC (Ross Chapel, Jere Roth), GE (Scott Murry, Fred Welfare) and others and offered our recovery plan and assistance to retrieve the fuel and move it to a safe haven.

The plan was accepted without modification.

Dispatched NEPSCO vehicles (crane, flatbed, and supervisor) to the accident site and coordinated preparation for fuel receipt at the proposed NU safe haven site located three miles from the accldent. 
Fron: B.N. Leach

8ubject: Documentation of Phone Conversation on Fuel Accident

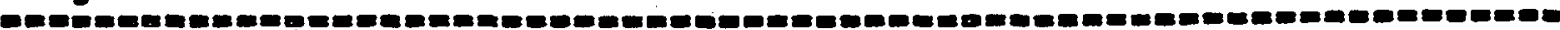

At about 0415 on December 16,1991, I received a phone call from the vermont yankee control room with the message that our fuel shipment had been involved in an accident on $I-91$. and that $1 \mathrm{t}$ was on IIre. The control Room upplied we with a phone number to call.

I lamedlately called the phone number, and talked to a captain in the springfield Fire Department. Be informed me that the fuel truck had been hit head on by a car. He stated that the truck was fully involved in fire.

I asked about the condition of the people involved and he informed me that no one was kilied, but that the two truck drivers, and the driver of the car vere in the hospital.

I asked him if the containers were open or had been damaged. Re stated that the fire was too intense to allow him to determine the condition of the containers.

He asked we how to fight the fire. I told him that he could use water to put the fire out, but to take the following precautions:

1. Have all fire Elghters down wind of the fire wear full turn-out gear, and SCBA's.

2. Have all fire fighters involved in fighting the fire and all equipment used, to remain on the scene until I arrive to survey them for contamination.

3. Treat the water used on the fire as contaminated, until I arrive and can determine if there was any contamination problem.

Be asked about the harards to the public if he let the fire burn itself out. I told him that an evacuation of $100 \mathrm{yds}$ around the Fire would be adequate, and that there would be no harard to the health and safety of the public, outside that area, from the radioactive material.

Be stated that since there was no threat to the pubilc from the Elre where the truck was located, that he would probably let it burn until I arrived to evaluate the potential contamination problem.

I told him that I would be there as soon as possible, with monitoring equipment. 
FED-B4-1992 10:53 FROM Wt Yankee Corp TO

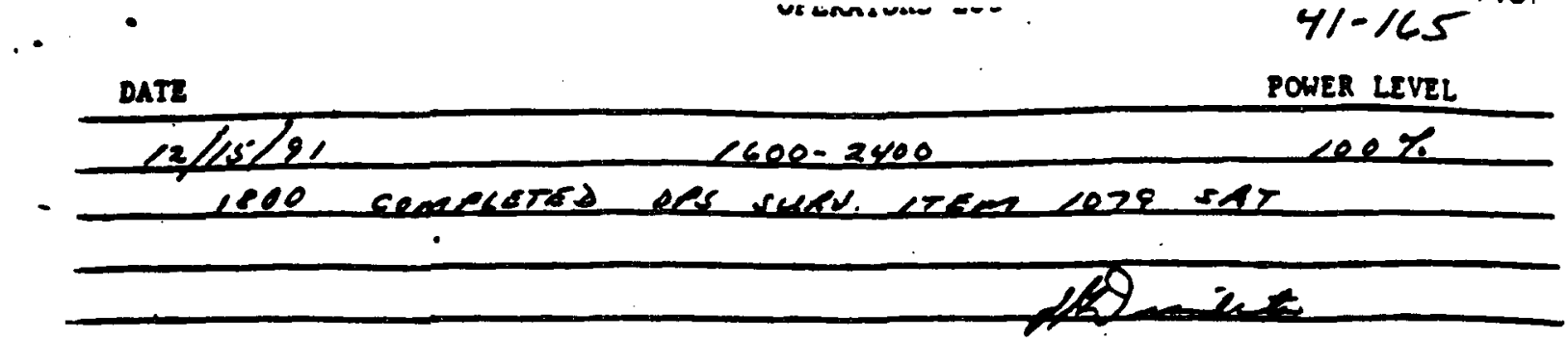

$12 / 15 / 9$ cese-ofwe $100 \%$

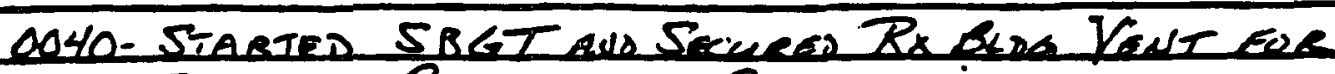

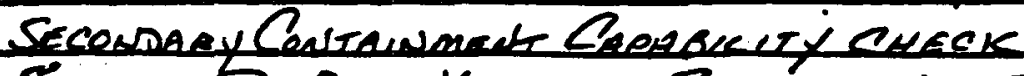

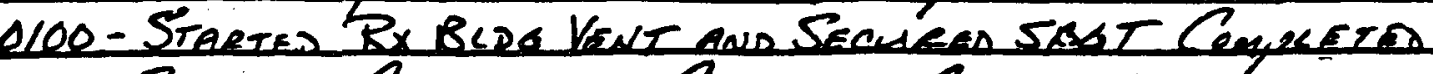

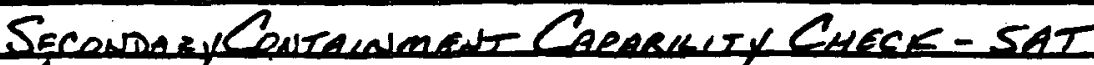

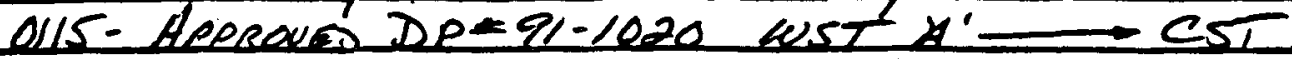

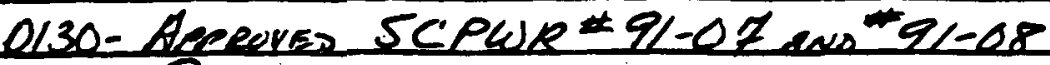

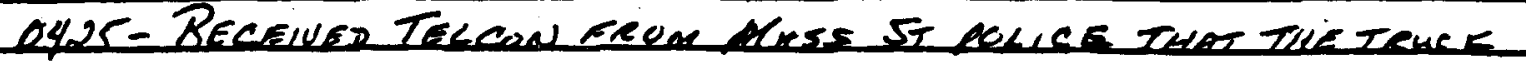

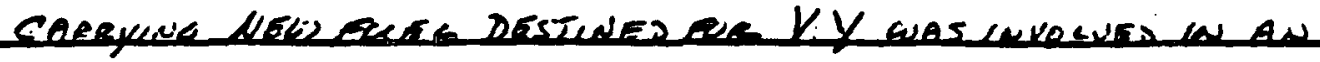

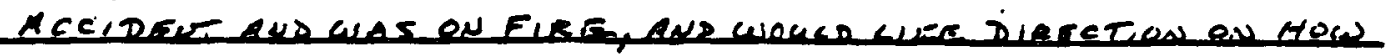

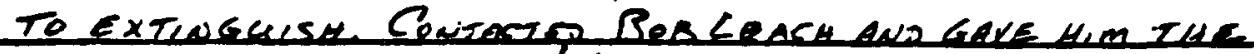

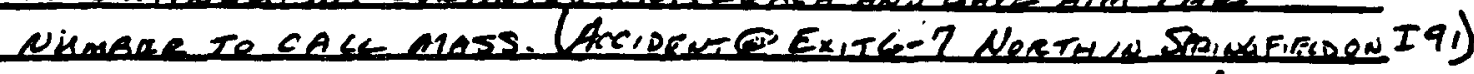

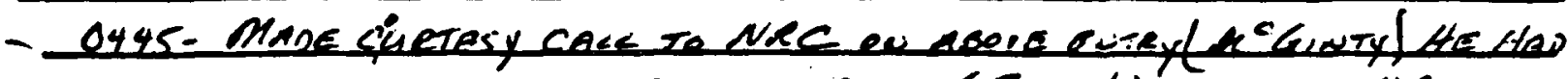

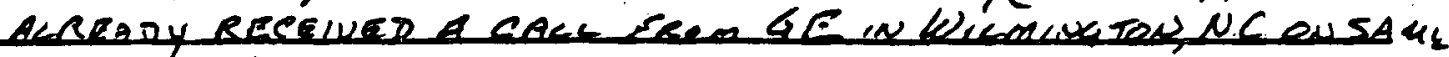

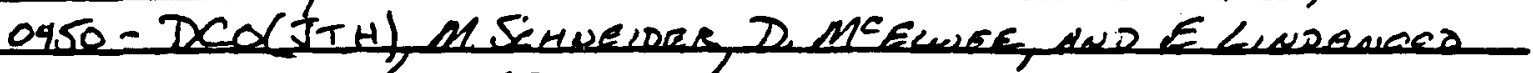

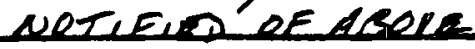

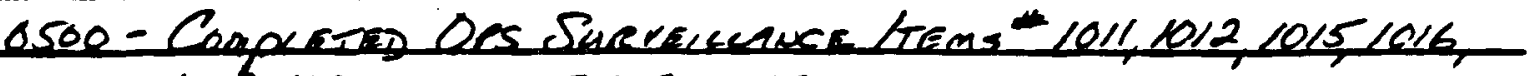
$1016,1020,1042,1049,1052,1055,106,1062,1069,1030,1053,1092$, $1096,109,2009,2084,2096,2235,2255,2269,3038,31193124$ $3134,3163,3167,316,3130,9029$

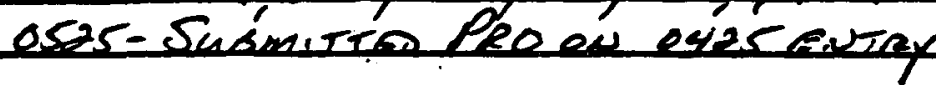

$12 / 16 / 91$ $0830-660$

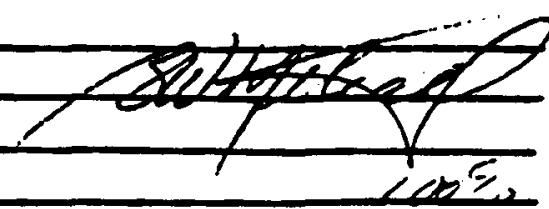

0810 - illade Uhur ndificarion to NRC (Koweh) an e425 entry. 10 CER $50.22 \mathrm{~h})(2)(\mathrm{VI})$. ristified ok mescure of 4 hese intificonim

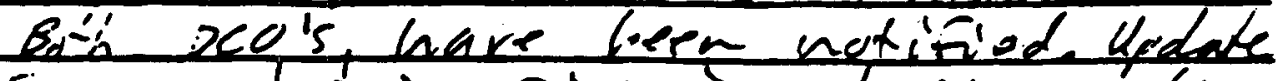

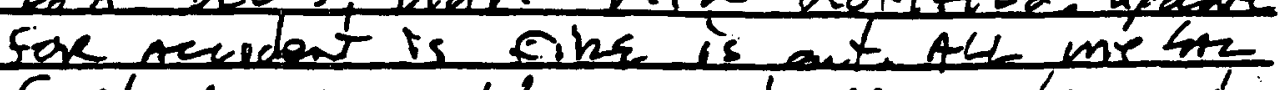
Fuel bexes ou the jeangl. No centomination fund As yet Ine inetiat hax re ief 
DATE $127(6 / 9)$

$$
080 u-1600 \text { tcont'd }
$$

POWER LEVEL

lus has blewn cut and ene metor lea is disteried and on he open Ne furl is entride ef benter

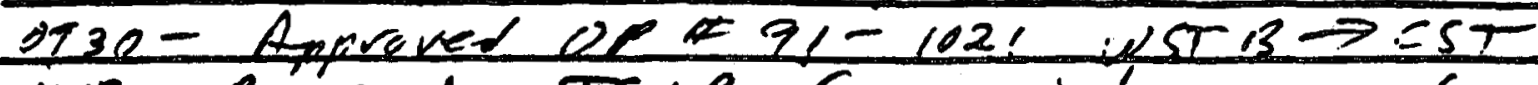
1011 - Bypursed TS IP fir maindenowes cheals din Buras asting

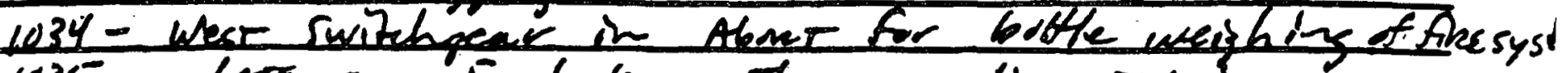
$1035^{\circ}$-updere on Farl bare. The ene litgarge is rame ane with blaw dut plus aut fuel wall be vecruted moved to a sope loven 2 metes from scene owwed by of utilities, chreked the shipged back to visinal pointof deponerues. wee-ReAlewed Tsip tenermal

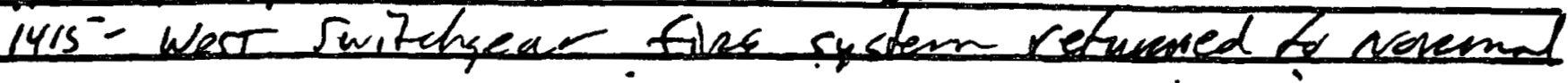
PMtute-

$12 / 16 / 91$ $1600-2400$ $100 \%$ centencested pever opesperow

$2 /(2 / 9)$ $0000-0800$ $100 \%$

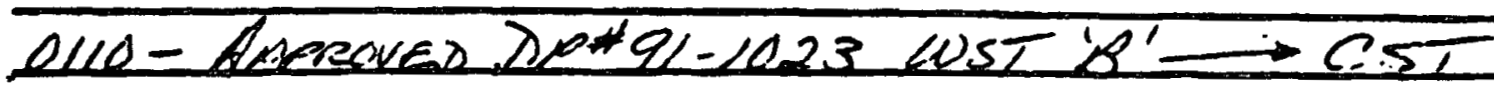

$12 / 12 / 9$ $0800-1600$ $48+2 x$

0800-Apperved SCPWR's 41-05 and $51-60$

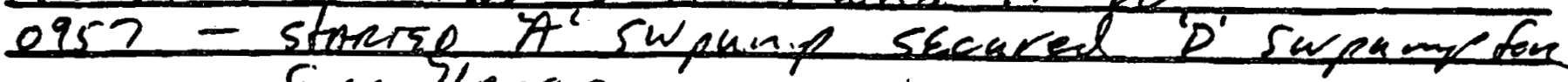
surveillowce.

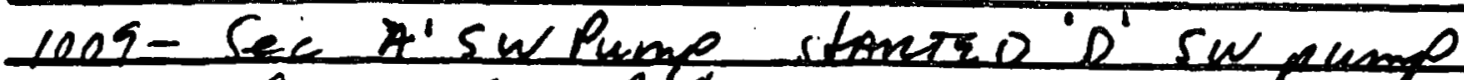
1012 - Approies of $I 1=1024$ WST B $\longrightarrow$ EST 1005 - Conyeted quadedy sw purap Survedlance, i swelemp still in abect fan viluation $(90-1323)$ 1220 - Stantse A'TBCou Pump See 'B'TBEew Pump Surapend to 


\section{DRTORAMTOT}

Tos R.E. Sojka

Date: January 29,1992

Frons B.N. Leach

8ubject: Documentation of Phone Conversation on Fuel Accident

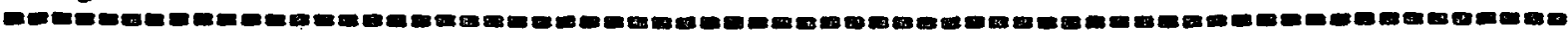

At about 0415 on December 16, 1991, I received a phone call from the Vermont Yanke control room with the wessage that our fuel chlpaent had been involved in an aceldent on I-91. and that it was on I1re. The Control Room supplied we with phone number to call.

I imediately called the phone number, and talked to a captain in the Springfield Fire Department. He informed me that the fuel truck had been hit head on by car. He stated that the truck was fully involved in fire.

I asked about the condition of the people involved and he informed me that no one was kilied, but that the two truck drivers, and the driver of the car were in the hospital.

I asked him if the containers were open or had been damaged. He stated that the fire was too intense to allow him to determine the condition of the containers.

He asked we how to fight the fire. I told hin that he could use water to put the fire out, but to take the following precautions:

1. aave all fire fighters down wind of the fire wear full turn-out gear, and sCBA's.

2. Have all fire fighters involved in fighting the fire and all equipment used, to remain on the scene until I arrive to survey them for contamination.

3. Treat the water used on the fire as contaminated, until I arive and can determine if there was any contamination problem.

ge asked about the hasards to the public if he let the ilice burn itself out. I told him that an evacuation of 100 yds around the fire would be adequate, and that there would be no harard to the health and safety of the public, outside that area, from the radioactive materlal.

Be stated that since there was no threat to the public from the fire where the truck was located, that he would probably let it burn until I arrived to evaluate the potential contamination problem.

I told him that I would be there as soon as possible, with monitoring equipment. 


\section{APPENDIX H \\ Summary of Telephone Conversations on December 16, 1991}

General Electric Company, Wilmington, North Carolina 
- 02-26-1992 01:22PM FROM U S NUCLEAR REGULATORY CO TO IXVOLUING TALEX ACC:SENT IN STRINGEZEJD. MASS. ON $12 / 16 / 91$

Late Fime From To Message

$12 / 16 / 910353-0404$ Sgt. Higgins. (Springkieid, Mass. Policé) (Ge securjty)

$12 / 16 / 910405$

GE Securjey

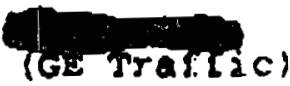

$12 / 16 / 910406$

$22 / 16 / 910408$

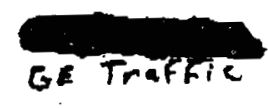

Sot. Higging

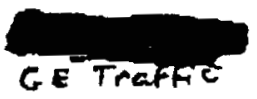
TEmergency
prep. Coord.)

12/16/910411-0422

GE Security

Emergency

Resporae

organization

$12 / 16 / 910415$

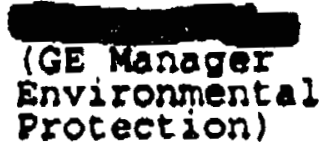

IGD Manager

Nuclear

safety

Engineering)

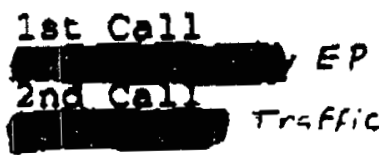

$12 / 16 / 910450=0510$

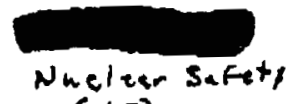
(NS)
Springeield PD Mr. Hanna. Dispatcher $\$ 3$
A McGil truck carrying nuclear material involved in a serious accident and is on $E$ ire. Sot. Higgins lete his police Department number and the soringfield Fire Department (FD) number.

Security relayed intormation and provided sgt. Higgigs telpohone number to GE Tratic

Discussion to determine which truck was involved.

Notification of situation.

Notsfication of situation.

Reviewed information.

$$
E P+\text { Treffic }
$$

Reviewed Information and developed response

prant, to callo to Springtiold fol.

$$
\text { Nuclear safety }
$$

Discussed incident, hipment contents, Dackaoing material types, and recommended they fight the fire. Mr. Hanna otated there was a command center at the scene and he would relay into to them. provided his nome number vis and the GE emergency control center number for contact. Ns di not receive cell at home and left for the plant at approx. 5:45 a.m.

- Actual times may vary by a few minutes 


\section{APPENDIX I}

\section{CHEMTREC Emergency Report No. 11838}


point of Contaot

\begin{tabular}{|c|c|}
\hline $\begin{array}{l}\text { Name: } \\
\text { Title: } \\
\text { organizations } \\
\text { Iooation: } \\
\text { Phone: }\end{array}$ & $\begin{array}{l}\text { OFPICER INNDRY } \\
\text { POLICE DLPARIMLAN } \\
\text { CHICOPEE, WABSACHUSEIT8 } \\
(413) 592-6341\end{array}$ \\
\hline
\end{tabular}

Alternate Phone:

Dot Name:

Common Name:

Mutual Ald :

shipper:

Coneignee:

Container:

carriar:

\section{URANIUY DIOXIDE}

N/A

UNKAOWN TO CAIIER

UNKNOMN TO CALLER

UNXNOON

Location: ON ROUTR 91

SPRINGFIELD, MA.

Tlme: 04:53

Problem: CALLER STATES THE CHICOPEB POLICE DEPARTMENT HAS BEEN CONTACTED BY THE SPRINGTIELD POLICE TO ASSIT IN RESPONDING TO AN ACCIDENT INVOLVING URANIUM DIOXIDE BUT THEY CAN FIND NO PRODUCT INFO AND ARE CALLING CHEMTREC FOR ASSISTANCE. NO INFO AVAILABLE IN THE OSAR BUT DEFINITION READ FROM THE CCD. ADVISED THAT I WOULD RESEARCH FURTHER AND CALL BACK. HE IS SEEKING INFORMATION ON TURNOUT. GEAR IN ORDER TO RESPOND, AS A FIRE IS ALSO REPORTED AT THE SCENE. REQUESTED A CALLBACK IF ANY FURTHER INPORMATION COMES HIS WAY.

Time: $\quad 05: 02$

NOTE: FOUND A GOOD URANIUM OXIDE MSDS IN DATABASE, SYNONYMOUS TO URANIUY DIOXIDE, HENCE...

OUT TO KR. IANDRY, CHICOPEE POLICE. ADVISED OF CHEVRON MSDS AND THAT I WOULD FAX TO 413-594-8396. DID SO.

Time: $05: 18$

IN FROM ERIC ARVEDON, EPA, BOSTON, SEEKING INFORMATION ON ENRICHED URANIUH. ADVISED OF CALĹ FROM THE CHICOPEE POLICE AND THAT THE PRODUCT WAS DESCRIBED AS URANIUM DIOXIDE. HE STATES THAT 500 KILOGRAYS OF "ENRICHED URANIUN ARE ENGULFED IN FLAMES IN A TRAILER." NR. ARVEDON THOUGHT HE WAS CALLING MASBACHUSETTS EPA AND WILL ATTEMPT TO DO 30, NOW.

Time: $\quad 05: 23$

IN FROM YR. IANDRY, CHICOPEE POLICE REPORTING HE HAS RECEIVED THE FAX. 
TLme: $05: 45$

IN FRON JEFF DON, ASSOCIATED PRES8, EPRINGFIELD, YA, IE STATES THIS INCIDENT INVOIVED A TRUCK AND CAR COLLIDING AND CATCHING ON FIRE IN DOWNTOWN 6PRINGFIEID. THE FIRE BURNED FOR APPROXIMATELY $1 / 2$ HOUR AND IB NOW OUT. HE ADVIEES THAT THE SHIPPER IS GENERAL ELECTRIC FROM WILYINGTON, BUT IS NOT BURE THAT WILMINGTON IS DELAWARE. HE ALSO HAS INFORUATION THAT THE BHIPUENT WAS IN FIREPROOF CONTAINERS. READ TO HIM FROY TIA CCD OA URNAIUY DIOXIDE.

\section{BCT}

TIme:

$07: 57$

IN FROX GLENN CATANIA, ACE HARDWARE CORP, ADVISING THAT HIS DRIVER WAS GTOPPED IN TRAFFIC SEVERAL HUNDRED FEET FROM THIS INCIDENT SCENE AND INHALED SMOKE FROM THE FIRE. THE DRIVER IS NOW EXPERIENCING A HEADACHE. CALIER IS SEEKING PDCT INFO FOR URANIUM OXIDE. PROVIDE INFO FROM CHEVRON MSDS. CALIER SAYS THAT THE PD ON HAND AT THE SCENE SAYS THAT THERE WAS NO REIEASE OF URANIUM OCXIDE. INFORMED CALLER THAT DRIVER MIGHT HAVE BEEN EXPOSED TO DECOMPOSITION PRODUCTS OF OTHER MATERIALS INVOLVED IN THE FIRE AND THAT HE OUGHT TO SEEK MEDICAL ATTENTION ASAP AS A PRECAUTIONARY MEASURE. A JED

T1me: $\quad 10: 16$

IN FROM STEVE UNGLESBEE, U.6. COUNCIL FOR ENERGY AWARENESS, PH: 202-293-0770. MR. UNGLESBEE ADVISES THAT APPARENTLY THERE WAS SOME CONFUSION REGARDING INFO PASBED TO THE ASSOCIATED PRESS REGARDING THIS INCIDENT. HE SAYS THAT THIS MATERIAL, WHICH HE IDENTIFIES AS FRESH NUCLEAR FUEL ALSO KNOWN AS ENRICHED URANIUN CONTAINED IN CERAMIC PELLETS HAS MINIMAI RADIOACTIVITY. HE FURIHER SAYS THAT PERSONNEL HANDLING MATERIAL ONLY NEED TO HAVE CLOTH GLOVES TO PROHIBIT CONTAMINATION OF THE MATERIAL. THERE IS NO NEED FOR PROTECTIVE CLOTKING/BREATHING APPARATUS TO PREVENT CONTAMINATION WITH THE RADIOACTIVE MATERIAL AS THE RADIATION HAZARDOUS ARE MINIMAL. CAIIER BELIEVES THAT THE ASSOCIATED PRESS IS UNDER THE IMPRESSION THAT THIS MATERIAL IS SPENT NUCIENR FUEL. ADVISED CALIER THAT THE CHENTREC COMNUNICATOR ON DUTY AT THE TIKE THIS RPT RECEIVED HAD PASSED INFO FROM THE CCD FOR URANIUM OXIDE TO THE ASSOCIATED PRESS. READ IR. UNGLESBEE INEO FRON THE CCD. MR. UNGLESBEE ADVISES THAT IIE WIIL TAX TO CHEMTREC A COPY OF THE ASSOCIATED PRESS STORY. HE WIIL ALSO FAX A COPY OF INFO PERTAINING TO THE PDCT INVOLVED.

Time: $\quad 10: 51$

STEVE UNGLESBEE, U.S. COUNCIL FOR ENERGY AWARENESS, CALLING TO DISCUESS THIS REPORT AND NEWS COVERAGE INVOLVED (SEE ATTACKED NEWS RELEASE). CHEMTREC WILL CONTACT JEFF DONN. ALSO, CNA-PR AND G.E.-PR WILI BE NOTIFIED.

HEM

T1me: $\quad 21808$

OUT TO JEFE DONN, BOSTON GLOBE, INFORMED HIM THIS IB NEW 
02/04/1992 14:02 CHEMICAL MFG RSSOC $\quad 2028871237 \quad$ P.03

CHEMTREC EMBRGENCY REPORT

CHMTREC Report Number: $11838 \quad$ Page: 03

NUCLEAR FUEL AND WAS YOT THE HMZARD AS FIRST REPORTED. INFORMED HIM THAT I WOULD CONTACT BOTH CMA-RP AND G.E. - PR. NR. DONN WOULD APPRECIATE HEARING FROM GENERAL ELECTRIC.

PLACED A CALL TO MA-PR THEY WILL EEND SOMEONE DOWN.

HEX

Time: 21:17

OUT TO GBNBRAL ELECTRIC NUCLEAR DIV. PASSED DETAILS TO BRUCE ADIER, 203-373-2726, INCLUDING NEWS COVERAGE. GAVE HIX JEFE DONN'S NAME AND PHONE NR POR CONIACI. G.E. WILL HAVE PROPER PERSON CAIT HIM.

* END OF TRNABISSION 
O4. $02 / 05 / 1992$ 13:22 CHEMICAL MFG ASSOC

in subjoet: $12 / 16$

2 : 260833 kadoctive Firo

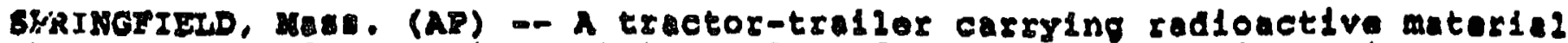
ashed and burned on an Interstat oaly todey, but authorsties aad none of - hazardous ubstance was roloasod and there was no fmnedlato danger.

Ho serlous lnfurled were raported when the truck colildad with a car and ret into flames on Interstate 91 in cowntown noar two largo hotels, tho tate $1100 \cos$.

A Elie dispatcher atd the truck we cerrying bout 11,000 pound of uranium oxide from the General Eloetrie plant in Milmington, $N . C .$, to the vermont nkee nuclear plant in Vornon, Vt.

"The radiosctive materdid is in teol container wo the hacard for leak 1a mowt nil," aid Bernio Wells, Elre departmont opokemman.

Witnesses sid two huge drum on the truck' flabed burned, aleng with throe

: four drums that soll on the roadway.

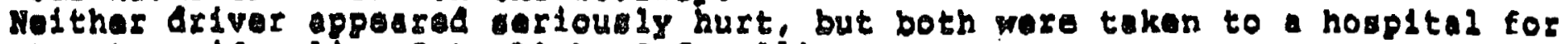
sotment. sidd police Bot. Rlchard Catelilor.

Members of tho tate and local poldco, the 11 re dopartment and the hazardour 15te team wer ot tho seone.

A spokesman for Chomical Transport Enorgoncy Center in Washington, who npoke 2. the condition of anonymity, ald the material, if raiased, hae "high

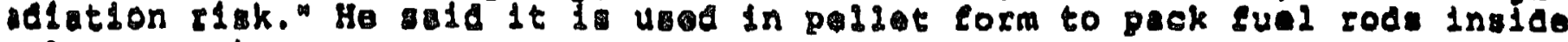
uminmr rasctora.

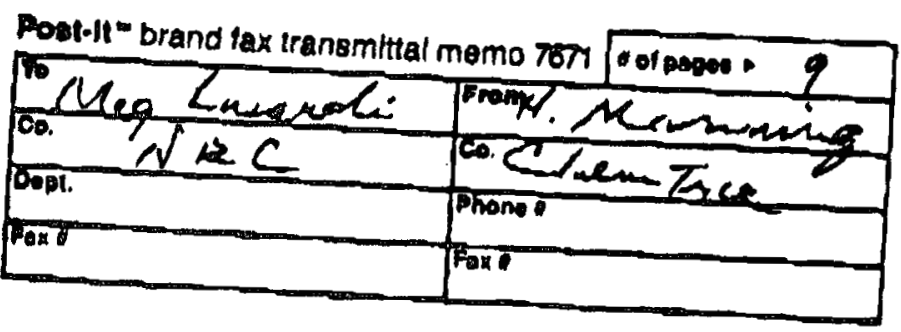


crilum-239. (U-238). The abundant isolope of uranium of which it comprives $99 \%$. It is not fluioanble, but will form plutonium-239 \& a ro whls of bamburdment by neutrous in a reactor. ite half-life is $4.51 \times 10^{\circ}$ yean. It will be uead in brader reactors, together with plutonium when tis energy potential will be explotied by tranemuting it to fusionable plutonium. Sere alio breader.

arandme carlide. See uranium dicurtide.

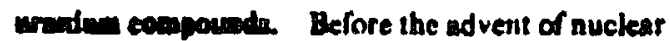
enorty. uranium had very limited uees. It had beca curgented for fllaments of lampe. $A$ imall tube of urunium dioxide, UQ, connected in se. rise with the lungaten filaments of large incandes. cent larps used for photography and motion pictures cends to eliminate the budden surge of current through the bulbs when the light is turned on, thereby exteriding their life. Compounda of uranium have bean uneal in pholography for toning and in the leather and wood indus. irio uranium compounds have boen used for thins and dyes. Uranium calis are mordants of silk or wnol. In making special slecth, a little ferrouranium has been utilized, but its value is quationable in this connection. Such alloys have not proved commercially stimactive. In the pro. duction of ceramict, sodium and ammonium di. uranates have been used to produce colored clanes.

Uranium curbide has been suggesied us a good catalyst for the production ol synthetic ammonis. Uranium salu in smull quantities are claimed to stimulate plan! growth, but large quantitie are alerly poiconous to plants.

By far the most imporiant use of uranium lie in it epplication for nuclear (or atomic) energy. Thit uee, in fact, has in increused the value of undium as to eliminate its use for meny of the purpowe mentioned above (Olenn T. Seaborg, "Encyclopedia of Chemical Elements. " od. by C. A. Hnmpel).

uradum docay cortes. (Uranium-radium series). The eerie of elenients produced as successive intermediate products when the clement uranium und foes spontaneous natural radianctive disin. torntion into lead. Rodium and radon are mem. ben of thils ceries.

mrentur, coploted. Uranium from which mosl of the uranium-235 iectope has been removed. Sec urnaium-238.

arealen dlearbed (urenium carbide). UC. Propertice: Oray crystals, d 11.28 (I8C), mp 2350C, bp $4370 \mathrm{C}$. decomposes in water, stightly ualuble in aloohol.
Hazard: Highly waic, radiztion riak.

Use: As crystals, pellets or mionoopberen for nuclear reactor niod.

mankerm Houdde. (uranium oxide; uranic oxide; uranif; vellowcake). CAs: $134457-6$. $\mathrm{UO}_{2}$

Properties: Black cryetals, ineoluble in water, soluble in nitric acid and conoentried ulfuric scid. d 10.9. mp 3000C.

Derivation of pure axide: Powdered uranium ore is digested with hot nitricawluric acid mixture and fittered to remove the ineoluble portion. Sulfate is precipitated from the colution with berium cartoonite, and uranyl nitrate is extructed with ether. Aner reextraction into water, it is heated to drive of nitric scid, leaving unanius trioxide. The latter is reduced with hydrofen to the dioxtde. Can be prepared from uranium hexalluoride by treating with ammonis and aubequent heal. ing of the ammonium diuranale. It is also recov. cred from phomphoric soid.

Ilazard: High redistion risk. Imite epontaneously in finely divided form.

Usc: A crystalline (or pellet) form is and to pack nuclear fud rodo.

uranium, onrtched. Narural uranium to which a few percent of the fisaionable 235-icotope has been added.

Sec alte enrichment.

uranium mexnfiuarde. CAS: 7783-81-5.

UF.

Properties: Colorless, volatile cryouls; sublimes: triple point 64.0C (1134mm); mp 64.5C (2 m1mospheres); d 5.06 (25C); soluble in liquid bromine, chlorine, carton tetrachloride, sym-letrachloroethane, and fuorocarbons. Reacts vigorously with water, alcobol, ether, and moed motals. Vi. por bohaves a nearly perfecl gas.

Derivation: (1) Triunajurn cotoxide $\left(U, O_{2}\right)$ and nitric acid react to form colution of uranyl nitrute; this is decomponed to UO, and reduced to the dioxide with hydroyen. The diaxide es a nuidized bed in reacted with bydrosen nuoride. The resulting tetrafluoride is flwortoned to the hexafluoride. (2) Triuranium octoxide is converted direcily to the hexnfluoride with hydrogen nuoride and fluorine, then purified by frectional distilletion.

Hezard: Highly corronive, redintion riak.

Use: Grecout diffusion proces for exparating icotopee of uranium.

unatum bydride UH.

Iroperties: Brown erey to black powder, d 10.92. conductor of eloctricity.

Derivation: Action of hydrogen on hot uranium. Hazard: Highly toxic. Ignites spontaneously in air. 
D2/05/1992 13:24 CHEMICAL MFG ASSOC $2028871237 \quad$ P.03

- CHVN

CHEVRON

137

Energency Munber (600) 457-2022 or (510)233-3737

Material Safety Data Sheet

CHEVRON

Material Safety Data Sheet

CHEVRON

materfal Safoty Data Shoet

CHEVRON

materlal Safety Data Sheet

CHEVRON

URANIVA OXIDE

Thts Matertal Safety Data Sheet contains environmental, health and toxicology information for your employees. Please make sure this information is given to them. It al so contains information to help you meet community right-to-know/emergency response reporting requirements under SARA Title 111 and many other laws. If you resoll this product, this MSDS must be given to the buyer or the information ineorporated in your MSDS. Diseard any previous edttion of this MSOS.

PRODUCT DISCONTIMUED. This Material Safety Data Sheet will no longer be updated.

\section{PROOUCT IDENTIFICATION}

URANIUM OXIOE

DANGERI - MARMFUL IF SWALLOWEO OR INHALED

- OVEREXPOSURE MAY AFFECT THE KJDNEYS

- CONTAINS RADIOACTIVE MATERIAL

- PROLONGED OR REPEATED SKIN CONTACT OR INMALATION MAY CAUSE CANCER

SYNONYM: YELLOWCAKE

PRODUCT MUNGER(S): C1344576

PRDDUCT INFORMATION: $(510) 842-5360$

Revision Number: 4 Revision Date: 12/04/91 MSDS Number: 003372 MOR - No Data Avaliabie NA - Not Applicable

Prepared According to the OSHA Hazard Communication Standard (29 CFR 1910.3200) by the Chevron Environmental Heaith Center. Inc.. P.0. Box 4054. Richmond, CA 94804. 


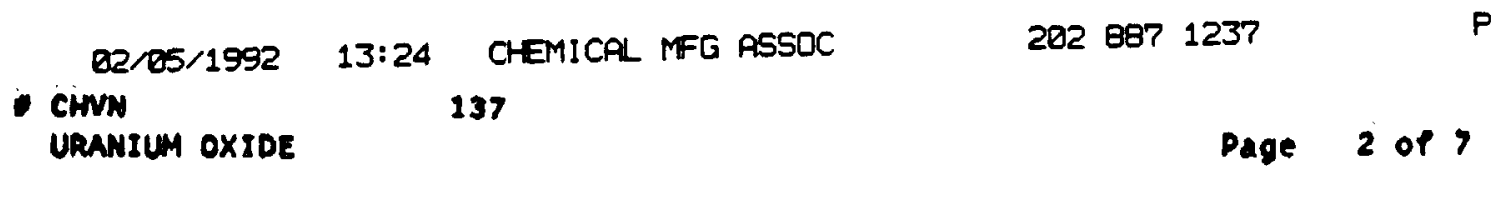

2. FIRST AIO - EMERGENCY MUMBER (800) 457-2022 OR (510)233-3737

EVE CONTACT:

Flush eyes Immodiately with fresh water for at least 15 minutes mile holding the eyelids open. Remove contact lenses if worn. No additional first ald should be necessary. However, if irritation persists, see a doctor.

SKIN CONTACT:

Remove contaminated clothing. Wash skin thoroughly with soap and water. See a doctor tf any signs or symptoms described in this document occur. Discard contcminated non-waterproof shoes and boots. Wash contaminated clothing.

INHALATION:

If thare are 1 gns or symptoms as described in this document due to breathing this material, move the person to fresh air. If breathing has stopped. apply artifictal respiration. Call a doctor. DO NOT ADMINISTER FIRST AID WITHOUT WEARING ADEQUATE RESPIRATORY PROTECTION.

INGESTION:

If swallowed, give water or milk to drink and telephone for modical advice. DO NOT make person vomit unless directed to do so by medical personnel. If medical advice cannot be obtained, then take the person and product container to the nearest medical emergency treatment center or hospital.

3. TMMEDIATE hEALTH EFFECTS - (ALSO SEE SECTIONS 11 : 12)

EYE CONTACT:

This substance may cause eye irritation due to the abrasive action of the dust. The degree of the injury will depend on the amount of material that gets into the eye and the speed and thoroughness of the first ald treatment. Signs and symptoms may include pain, tears, swelling, redness, and blurred vision.

SKIN IARITATION:

This substance ts not expected to cause prolonged or stgnificant skin irritation.

DEAMAL TOXICITY:

The dermal toxicity of this substance has not been determined. However, it may be slightiy toxic to internal organs if absorbed through the skin. The degree of injury will depend on the amount absorbed. Read the Addtional Health Data section (12) of this doçument for more information. RESPIRATORY/INHALATION:

This substance is highly toxic to internal organs if inhaled. The degree of injury will depend on the airborne concentration and duration of exposure. This hazard evaluation is based on the known toxicity of the ingredients in this substance. The target organ(s) is the kldney. Read the Additional Health Data section (12) of this document for more information.

INGESTION:

Th1s substance is highiy toxic to intermal organs if swallowed. The

Revision Number: 4 Reviston Oate: 12/04/91 MSOS Mumber: 003372 MDA - No Data Available MA - Not Applicable 
dogree of injury will depend on the anount absorbed. This hazard evaluation is based on the known toxicity of the 1ngredients in this substance. The target organ(s) is the ktdney. Read the Additional Health Data section (12) of this document for more information.

\section{PROTECTIVE EQUIPMENT}

EYE PROTECTION:

Do not get this material in your eyes. Eye contact can be avolded by mearing chomical goggles.

SKIN PAOTECTION:

Avold contact with skin or clothing. Skin contact should be minimized by wearing protective clolhing including gloves.

RESPIRATORY PROTECTION:

Woar approved respiratory protection when working with this material. An air-supplying resptrator is recommended.

VENTILATION:

Ventilation must be demonstrated to be adequate to keep dirborne concentrations of this material below the recommended exposure standards prtor to using thts material.

\section{FIRE PROTECTION}

FLASH POINT: NA

AUTOIONITION: NA

FLAMMABILITY LIMITS (t by volume in air): Lower: NA Upper: NA EXTINQUISHING MEDIA:

CO2, Dry Chemical, Foam, Alcohol-type Foam, Water Fog.

NFPA RATINGS: Hedith 2; Flammabllity 1; Reactivity O; Special MDA;

HMIS RATINGS: Mealth 2; Flammability 1; Reactivity 0; Other NOA;

(Least-0, Slight-1, Moderate-2, High-3, Extreme-4). These values are obtained using the gutdelines or published evaluations propared by the National fire Protection Association or, If applicable, the National Paint and Coating Assoctation, and do not necessarliy reflect the hazard evaluation of the Chevron Environmental Healen Center. Read the entire document and label before using this product.

FIRE FIGHTING PROCEDURES:

For pires involving this material, do not enter any enclosed or confined fire space without proper protective equipment, including self-contained breathing apparatus. COMBUSTION PROOUCTS:

Heating this material may produce RADIOACTIVE PRODUCTS

6. Storage, handLimo, and reactivity

HAZARDOUS DECOMPOSITION PRODUCTS:

MDA

Revision Muber: 4 Revision Oate: 12/04/91 MSDS Number: 003372 MOA - No Data Avallable NA - Not Applicable 
STABILITY:

stable. Avold high temperatures. MRAROOUS POL YMERIZATION:

Polymerization will not occur.

INCOMPATIEILITY:

NOA

SPECIAL PRECAUTIONS:

READ AND COSERVE ALL PRECAUTIONS ON PRODUCT LABEL.

\section{PHYSICAL PROPERTIES}

SOLUBILITY: SOluble in HC1, H2SO4, HNO3 and H3P04; insoluble in water.

APPEARACE: 01 ive green-black powder.

BOILING POINT: NA

MELTING POINT: $1300 \mathrm{C}$ DECOMPOSES

EVAPORATION: NA

SPECIFIC GAAVITY: $8.30 \bigcirc 13.6 / 15.6 \mathrm{C}$

VAPOR PRESSURE: NA

PERCENT VOLATILE (VOLUME 6): NA

VAPOR DENSITY (NIRE1): NA

VISCOSITV: NA

MOLECULAR WEIGHT: 842.09

8. ENVIROMENTAL CONCERNS, SPILL RESPONSE AND DISPOSAL

CHEMTREC EMERGENCY PHONE NUMBER: (800) 424-9300 (24 hour).

SPILL/LEAK PRECAUTIONS:

Certain geographical areas have air poliution restrletions concerning the use of material in work siluations which may release particulate contaminant to the tmosphere. Air pollution regulations should be studied to determine if this material is regulated in the area where it is to be used.

If this material is released into a work area, evacuate the area immediately. Persons entering the contaminated area to correct the problem or to determine whether it is safe to resume normal aclivities must comply with all instructions in the Protective Equipment section. DISPOSAL METHOOS:

Place contaminated materials in disposable containers and dispose of in a manner consistent with applicable regulations. Contact local environmental or health authoritles for approved disposal of this matertal.

9. EXPOSURE STANDARDS, REQULATORY LIMITS AND COMPOSITION

COMPOSITION COMMENT:

All the components of this materlal are on the Toxic substances control

Revision Number: 4

Revision Date: 12/04/91

NDA - Mo Data Avatlable

MSDS Number: 003372

NA - Not Applicable 
$\begin{array}{llllll}\text { Q2/85/1992 } 13: 26 & \text { CHEMICAL MFG ASSOC } & 202887 & 1237 & \text { P.07 }\end{array}$

(c)

CHYM 137

URANIUN OXIDE

Page 5 of 7

Act Chemical Substances Inventory.

The percent composttions are given to allow for the various ranges of the components present in the whole product and may not equal $100 \%$.

PERCENT/CAS\# COMPONENT/REQULATORY LIMITS

100.0 URANILM OXIDE

CONTAINING

- 82.0 URANIUA OXIDE

CAS1344576

$-1.0 \%$ SULFUR

CA57704349

- $1.0 \%$ ZIRCONIUM

CAS7440677 $5 \mathrm{mg} / \mathrm{m3}$ ACGIH TLV

$10 \mathrm{mg} / \mathrm{m} 3$ ACGIH STEL

$5 \mathrm{mg} / \mathrm{m} 3$ OSHA TWA

$10 \mathrm{mg} / \mathrm{m} 3$ OSHA STEL

< 1.08 MOLYBOENUM

CA57439987 $5 \mathrm{mg} / \mathrm{m} 3$ ACGIH TLV

$5 \mathrm{mg} / \mathrm{m} 3$ OSHA TWA

< $1.0 \%$

CALCIUM

CAS7440702

$<\quad 1.0 \%$ SILICON

CAS7440213 $10 \mathrm{mg} / \mathrm{m3}$ ACGIH TLV

$5 \mathrm{mg} / \mathrm{m}_{3}$ OSHA TWA
TLV - Threshold Limit Value
TWA - Time Welghted Average
STEL - Short-term Exposure Limit
TPO - Threshold Planning Quantity
RQ - Reportable Quantity
CPS - CUSA Product Code
CC - Chevron Chemical Company
CAS - Cnemical Abstract Service Number

10. REGULATORY INFORMATION

DOT SHIPPING MAME: NDA

DOT HAZARD ClaSS: NDA

DOT IDENTIFICATION MUMER: NDA

SARA 311 CATEGORIES: 1 . Immediate (ACute) Health Effects; YES

2. Delayed (Chrontc) Healeh Effects; YES

3. Fire Hazard; NO

4. Sudden Release of Pressure Hazard; No

5. Reactivity Hazard; No

The following components of this material are found on the regulatory

Revision Number: 4 Revision Date: 12/04/91

MSDS Number: 003372

NDA - No Data Avallabie

MA - Not Applicable 
$\begin{array}{lllll}\text { Q2/05/1992 13:27 CHEMICAL MFG RSSOC } & 2028871237 & \text { P.08 }\end{array}$

CHVN
URANIUM OXIDE
Uage 6 of 7

lists indicated by the number below the component name:

MOLYEDENMM

1s found on 1ists: $02,10,11,13,14,17,28$,

SILICON

is found on 11sts: $10,11,13,14,17$,

ZIRCONIUA

ts found on lists: $02,10,11,14,15,17,18$,

Calcium

is found on lists: $02,10,11$.

SULFUR

is found on 1tsts: $02,10,11$.

RECULATORY LISTS SEARCHED:

OImsara 313

ofaca prop. 65

O7-IARC Group 2A

10=PA RTK

13WWN RTK

19-chevron TLV

220 (a) (e)(f) 23-TSCA Sect 6

25-TSCA sect $8(a) \quad 26$-TSCA sect $8(d)$

2000SHA CEILING
O2AMSS RTK

OSAMI 406

OB-IARC Group 2B

11=N RTK

$14=A C G I H$ TLV
20-EPA carcinogen
03-NTP Carcinogen

06-IARC Group 1

OD=SARA $302 / 304$

12=CERCLA 302.4

15=ACGIH STEL

18EOSHA STEL

$21=$ TSCA sect $4(e)$

24=TSCA sect 12(b)

28ecanadian WHMIS

11. PRODUCT TOXICOLOGY DATA

EYE IRRITATION:

No product toxicology data available. The hazard evalualion was based on data from similar materials.

SKIN IRRITATION:

No product toxicology data avaliable. The hazard evaluation was based on data from simflar materials.

DERAML TOXICITY:

No product toxtcology daca available. The hazard evaluation was based on data from similar materials.

RESPIRATORY/INHALATION:

No product toxicology data available. The hazard evaluation was based on data on the components.

INGESTION:

No product toxicology dala available. The hazard evaluation was based on data on the components.

12. ADDITIONAL HEALTH DATA

ADDITIONAL MEALTM DATA COMMENT:

The primary hazerd to personnel working with uranium oxide (U30B) is absorption of U30B through inhalation or by contamination entering the mouth. Contarnination can also enter the body through any breakage of the 
kin. If too much U308 is absorbed, uranium metal polsoning can occur causing danage to the kfdney. This appears to be more or a hazara than the radiological hazard. The specific activity for U308 is $6.77 \times 10-7$ curies per eran of urantum.

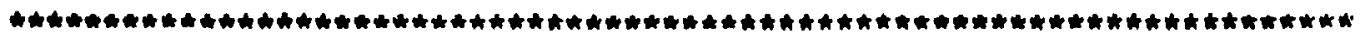

The above information is based on the data of witch we are aware and is belfeved to be correct as of the date hereof. Since this information may be applied under conditions beyond our control and with which we may be unfantliar and since data made available subsequent to the date hereof may suggest modiffeation of the information. we do not assume any responsibility for the results of lis use. Thts information is furnished upon condition that the person recelving it shall make his own determination of the sultablitty or the matertal for his particular purpose. 


\section{APPENDIX J \\ NRC Response to Accidents Occurring During the Transportation of Radioactive Material; General Statement of Policy, 49 FR 12335, March 29, 1984}


the Depertment of Traneportation Act (40 U.S.C. 101, of sep.) and the Hazardou Materiale Tranoportation Act (19 U.S.C. 100n-1012). is required to repulate eafoty in the tranportation of besardous materials. theluding radiosctive materials. Pertinent DOT regulations are containod is 10 CrR Part 100 to 17.

The roles in regulatory responalbility of NRC and DOT bave been dolineated in a Memorendum of Undarutandins (MOU) between the two esencies dated June a 1978 ( $41 \mathrm{FR}$ 3e000). The MOU doee not define the epeeffic responalbilitien of each auency in responding to tranportation eceidents or incidente. However. to all accidents.

MPC Roeponce to Acokdemts Decurring Durthe the Trencporteten of Rediocettre Materiet; comor. Etatement of Pawey

\section{acaver: Nuclar Repulatory} Comminator. acnon: Ceneral Statement of Policy. unmunr: The Nuclear Regulatory Commisoion (NRC) bas defined in reneral policy atatement its role in responding to eccidente and incidents related to the tranportation of aucleas materials. The purpose of the policy statement is to state clearty the extent of the NRC's participation and involvement in reoposding to auch a transportation accident or incident.

ormetrve oars: March 20, 1904. pon runnten miromantom comracts. Dr. Juntin T. Long. Office of Nuclear Material Safety and Safeguards. U.S. Nuclear Regulatory Commiosion. Waehington. D.C. 2055s, telephone (301) 427-1135

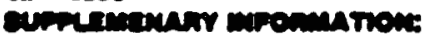

Beckowand

The Nuclear Regulatory Comminaion (NRCh, under the Alomic Energy Act of 1054. as amended (42 U.S.C. Chopter 23) and exction 201 of the Enery

Reorenization het of 1974, as ameaded (42 U.S.C. sen1), it enthorized to license and resulate the recelpt, posseasion, we. and tranfer of "byproduct matarial." "bource materitel" and "epecial nuchar material" (as defined in 42 U.S.C. 2ol4). The NRC euthority to licenes air ahipmeal of plotoatum is further poverned by Pub. L CA-7. Pertinent NRC regulations are conchined in 10 CRR Purt sa 4a 70 72. and 72

The U.S. Departinent of Trensportation (DOT), under the Dengerou Carjo Act R. \& 472 a amended 10 U.S.C 170). Tite V and car(h) of the Foderal Aviation Aet of 2000 ( 10 U.S.C 1421-1400 and 2452(b)). treidents. and instances of actual or auspended leakage involving packages of rediosctive material rogulatod by the NRC. the MOU essigns to NRC the reoponaibility to act as lead agency for investigating the cause of the leaknge and preparing e report of the investigation.

The Foderal Emergency Managemeat Agency (FEMA) is responaible for prepariag a Federal Radiological Emergency Reuponse Plaa (FRERP). On December 23. 1000. FEMA published "Master Plan" for commenclal nucleas power plant aceddents (45 FR MM10). Development of the FRERP. which is echeduled for completion in 1004 , entale revision of the "Master Plan." including its expanalon to tecorporate provisions for responding to all types of pescetime rediological emerzencies Including transportation accideats. Availebility of planning guidance for developing the FRERP was noticed in the Fodren Redister on April 28 1003 (10 FR 10220). The FRERP will be based on the plennins guidance and on the renults of - Full Field Exeretee conducted in the vicinity of the St. Luele audear power plent in March 2004.

The responee to transportation accidents is loas structured than the radiological emergency reupones to -ccidents at llacaned oltee becaure of the uncertainties surrounding (1) the location where the acoldent occurs. (2) the diversity of iuthority of thoue who will be responding. and (3) the likely limited rediation knowledge of the first. on-scene respondars (who are uevally local officialo). The states bave the primery responsibulity for protecting the health and eafoty of the etriesar from public hezerda. Recognition of the responsibilitien for radiation harards is reflected by the exdatence of an eppropriately desifrated otete agency chartared with the reapoatibility of responding to rediolosical emergencies. 
Twa existing Momorandim of Understandins between the Dor and the NRC (mentloned above) ascipin NRC the repposolbility for the revulation and certification of abipping containere for findile matertale and for other radioactive materiuls (uther then low specific ectivity materialo) in quantities exceeding Type A limits es defined in 20 CFR Part 71. The MOU assigne DOT the reoponsibility for regulation of most other aspects of zuctear trenportation ectivitiea. DOT operetes a Nabonal Response Center which serves to relay information conceming transportation. uncidents involving hesardous matarials. Dor regulations require carrier, at the eartied precticable moment, to give aotice to the National Response Ceater after an theldant oceurs during the course of transportation in which. emong other thingu fire, breakage. ipillirge, of suspected radiosctive contamination occura involvin shipment of radiosctive moterial. Ench notification of a transportation incident of any kind is relayed by the National Reaponse Center to the Regional Office of the Environmental Protection Agency (EPA) for incidents on land or to the U.S. Coast Guard Captain of the Port for incidente in naviguble waters. When a reported incident is known to involve radioactive material, notification is also made to the Regional Coordinating Office for Radiological Assiatance of the 21.S. Department of Energy (DOE) and to the Regional Office of the Nuclear Regulatory Commiasion. NRC my also become aware of a transportation incident through other channels. such as the shipper. the carrier. or the police or highway potrol.

DOE has stated that DOF:s involvement is the maintenance, ot about 30 sites. of teams of technically trained auclear and transportation opecialiate available to assist states. upon requeut by providing desired advice and counsel in areas where states may aeed assistance. Such teams are highly professional and are equipped to provide analytical and diagnostic support, but nol to become involved in cleanup activities. Such teams operate under the DOE Radiological Aasiatance Program or the Federal Radiological Monitoring and Assesumeat Pian (DOE. coordinuted).

The Commistion invites all trterested persone who desire to submit written comments of suggestions on this general statemeat of policy to send them to the Secretary of the Commisuion. United States Nuclear Regulatory Commiesion. Washington. D.C. 2055s. Attention: Docketing and Service Branch by fuly 27. 18a.
Condderation will be drea to weh oubinisatons in connoction with pastible future revition of the etated polloy. Coples of commeats raceived mey be exemined at the Comminatos's Publle Document Room. 2717 H Strest N.W. Weahington D.C.

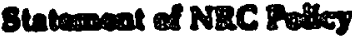

In any cocideat or fincident cocuritn in connection with the tranportation of ridionctive meterial is which aport is required to be sent to the Nationd Response Center by DOT regulations in 40 CFR 171.19. NRC rediatios safety essessment actions will conclat of the following.

Cull the agency designated by the affected sinte to reupoad to tremportation eceidento isvolvin radioective materials 800000 practicable to enours that agency hes been informed of the incident (The State government is responsible for assuming control of the eccident scene to protect the health and safety of the public.)

-Offer NRC technical agsistance in the form of information, advice. and evaluations to the State at the time the initial notification is made to the appropriate State agency.

- Assure ewareness of the incident by the DOE and other affected agencies. including any agencies specifically designated by the Federal Emergency Management Agency.

-Maintain awareness of the situation until normal conditions ere restored at the scene of the eccident.

-Provide information on packaging characteriatics in response to any query regarding NRC-approved packagea.

- Respond to requests for information on NRC activities in connection with the eveat. Requests for specific information on an accident normally will be referred to the eppropriate State agency, or to the DOE if the situstion relates to DOE activities. -If the shipper is an NRC liconsee. enoure that the shipper provide complete and eccurate informetion concerning the pedioective meterial and details of the shipment to emergency reeponce personnel. - In sccordance with the NRC-DOT Memorandum of Underatanding. ect a lead agency for investigating all accidents, incidente, and instunces of ectual or suppectod leakege involving packagee of radioective material regulated by the NRC. Any NRC personnel at the scene of a traneportation acoddent will notty the on-ecene coordtantor of this or ber presence and anake clear that unlen
NRC acalstnes is requented by the on-eane coordingtor. NRC sctivities will be primerly linited to informetton collection.

- Provide recommondations to emergency response parsonnd an rodiolo deal Loues if NRC assistance should be requented by the on-ecen coordinator of if a need is recognied by NRC persoond.

The policy here wet forth rolates solely to radiological concerne. Responding to any attempt to sted or abotuge a shipment of aucleer moterial is a responsibility of the Federal Burenu of Investigation (FBI) as delinsated in the NRC/FaI Mernoranduni of Understandins dated Aprll 27, $197 \%$ and published December 20 1972 at 4172 73535.

Dated ot Washington D.C. thes and day of Marath ices.

Por the Nuchar Regulatorg Compinaton. Sarened J. Cuill.

Socretary of the Canmission.

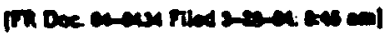

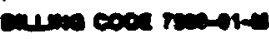




\section{APPENDIX K}

Guide 63 from the 1990 Emergency Response Guidebook, U.S. Department of Transportation; DOT P 5800.5 


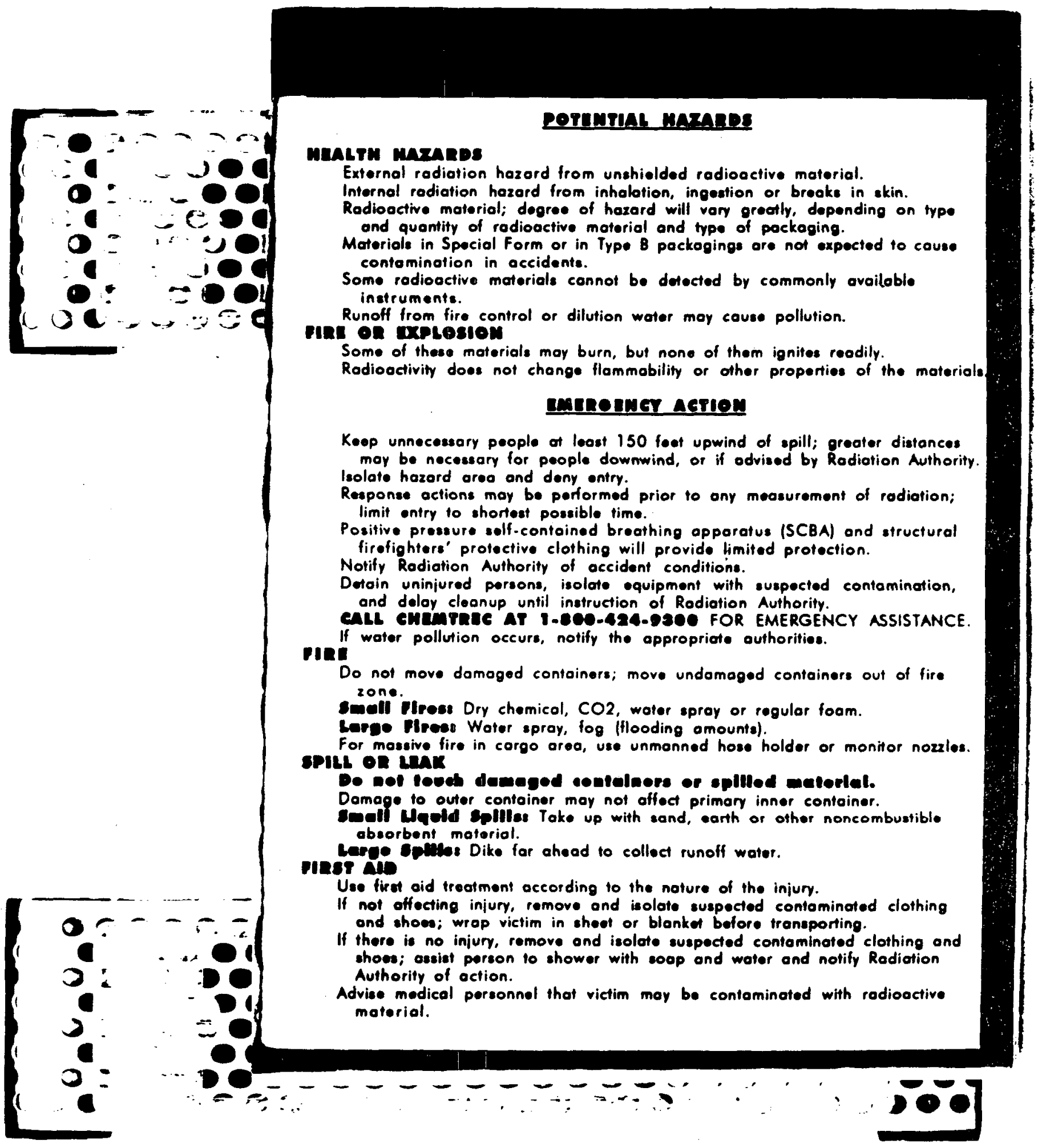




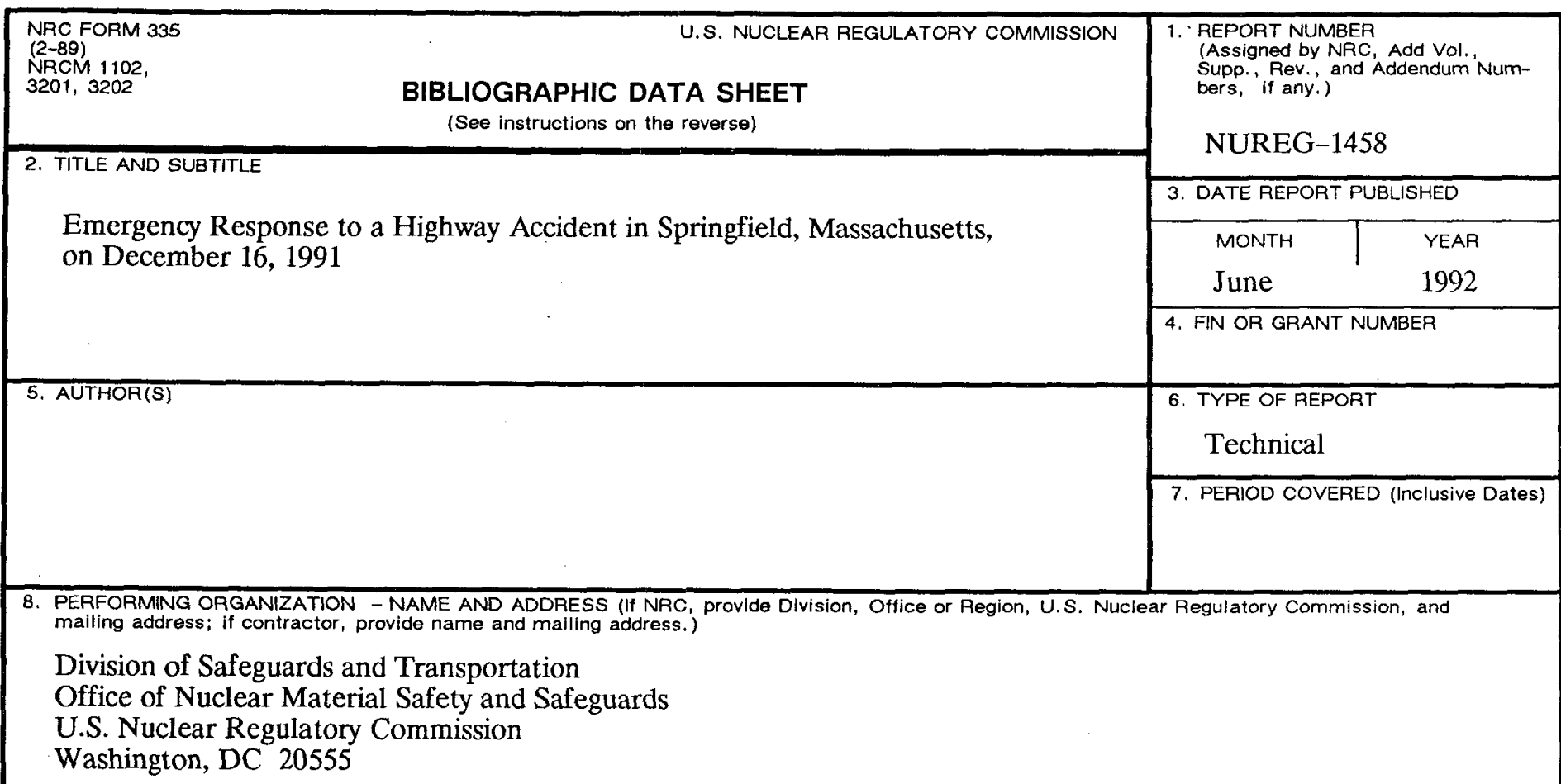

9. SPONSORING ORGANIZATION - NAME AND ADDRESS (If NRC, type "Same as above"; If contractor, provide NRC Division, Office or Region, U.S. Nuclear Regulatory Commission, and mailing address.)

Same as above

10. SUPPLEMENTARY NOTES

11. ABSTRACT (200 words or less)

On December 16, 1991, a truck carrying unirradiated (fresh) nuclear fuel was involved in an accident on U.S. Interstate 91, in Springfield, Massachusetts. This report describes the emergency response measures undertaken by local, State, Federal and private parties. The report also discusses "lessons learned" from the response to the accident and suggests areas where improvements might be made.

\begin{tabular}{|c|}
\hline $\begin{array}{l}\text { 13. AVAILABILITY STATEMENT } \\
\text { Unlimited }\end{array}$ \\
\hline 14. SECURITY CLASSIFICATION \\
\hline (This Page) \\
\hline Unclassified \\
\hline (This Report) \\
\hline Unclassified \\
\hline 15. NUMBER OF PAGES \\
\hline 16. PRICE \\
\hline \\
\hline
\end{tabular}


THIS DOCUMENT WAS PRINTED USING RECYCLED PAPER 